\title{
Copper-catalyzed Oxidation of Hydrazones to Diazo Compounds Using Oxygen as Terminal Oxidant
}

Wenbin Liu, ${ }^{1+}$ Jack Twilton, ${ }^{2}$ Bo Wei,,${ }^{1}$ Maizie Lee, ${ }^{1}$ Melissa N. Hopkins, ${ }^{2}$ John Bacsa, ${ }^{1}$ Shannon S. Stahl, ${ }^{2^{*}}$ and Huw M. L. Davies ${ }^{1 *}$

${ }^{1}$ Department of Chemistry, Emory University, 1515 Dickey Drive, Atlanta, Georgia 30322.

${ }^{2}$ Department of Chemistry, University of Wisconsin - Madison, 1101 University Avenue, Madison, Wisconsin 53706.

Authors contributed equally.

Email: $\underline{\text { stahl@chem.wisc.edu }}$

hmdavie@,emory.edu

Contents

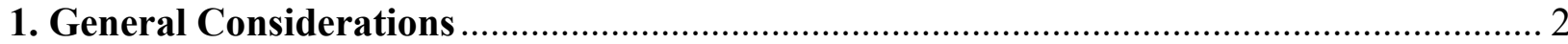

3. Hydrazone Oxidation and Product Characterization ............................................. 12

4. React-IR Experiment Set-up and Procedure .......................................................... 22

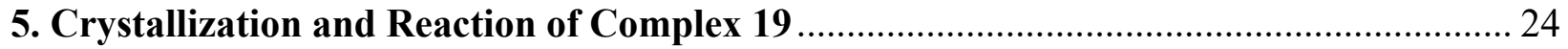

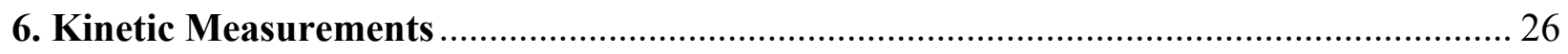

7. Optimization of Diaryl Hydrazone Oxidation............................................................ 29

8. Diaryl Hydrazone Oxidation and Product Characterization ......................................... 31

9. Tandem Cu-Catalyzed Hydrazone Oxidation and Rh-Catalyzed Carbene Transfer ...... 35

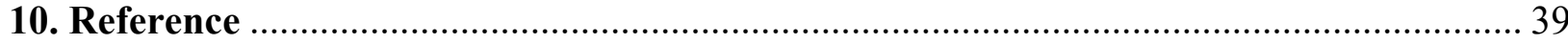

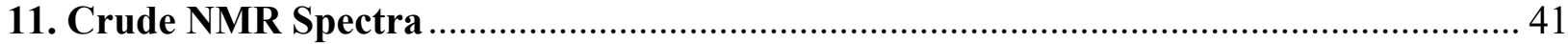

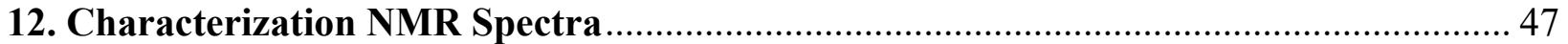




\section{General Considerations}

Caution: Diazo compounds are high energy compounds and should be handled with caution. Although we have no difficulties with working with these compounds, it is advisable to carry out reactions behand a blast shield. Hydrazine hydrate is highly toxic and needs to be handled using the established safety protocols.

All solvents for reactions were purified and dried by a Glass Contour Solvent System unless otherwise stated.

Thin layer chromatographic (TLC) analysis was performed on Kieselgel 60 F254 aluminumbacked silica plates, visualizing with UV light and/or staining with aqueous $\mathrm{KMnO}_{4}$ stain. Flash column chromatography was conducted using silica (SiliaFlash ${ }^{\circledR}$ P60, 40-63 $\mu \mathrm{m}$ ) and diethyl ether/hexane as elution solvent as indicated.

${ }^{1} \mathrm{H}$ and ${ }^{13} \mathrm{C}$ NMR spectra were recorded at $600 \mathrm{MHz}\left({ }^{13} \mathrm{C}\right.$ at $\left.151 \mathrm{MHz}\right)$ on Bruker-600 spectrometer or IVONA-600 spectrometer or at $400 \mathrm{MHz}\left({ }^{13} \mathrm{C}\right.$ at $\left.101 \mathrm{MHz}\right)$ on a Bruker Avance III 400 spectrometer at $25{ }^{\circ} \mathrm{C}$ or a at $500 \mathrm{MHz}(13 \mathrm{C}$ at $125.7 \mathrm{MHz})$ on a Bruker Avance III 500 spectrometer at $25{ }^{\circ} \mathrm{C} .{ }^{19} \mathrm{~F}$ NMR spectra were recorded at $376 \mathrm{MHz}$ on VNMR-400. Unless otherwise stated, NMR spectra were run in solutions of deuterated chloroform $\left(\mathrm{CDCl}_{3}\right)$ with tetramethylsilane (TMS) as an internal standard $\left(0 \mathrm{ppm}\right.$ for ${ }^{1} \mathrm{H}$, and $0 \mathrm{ppm}$ for $\left.{ }^{13} \mathrm{C}\right)$, and were reported in parts per million $(\mathrm{ppm})$. Abbreviations for signal multiplicity are as follow: $\mathrm{s}=$ singlet, $\mathrm{d}=$ doublet, $\mathrm{t}=$ triplet, $\mathrm{q}=$ quartet, $\mathrm{m}=$ multiplet, $\mathrm{dd}=$ doublet of doublet, etc. Coupling constants ( $J$ values) were calculated directly from the spectra.

IR spectra were collected on a Nicolet iS10 FT-IR spectrometer and reported in unit of $\mathrm{cm}^{-1}$.

Mass spectra were taken on a Thermo Finnigan LTQ-FTMS spectrometer with APCI, ESI or NSI or a Thermo X Exactive Plus ${ }^{\mathrm{TM}} \mathrm{Q}-\mathrm{IT}-\mathrm{MS}$ with ESI.

Melting points (mp) were measured in open capillary tubes with a Mel-Temp Electrothermal melting points apparatus and are uncorrected.

In situ IR monitoring experiments were carried out with a Mettler Toledo ReactIR 45m instrument equipped with a $9.5 \mathrm{~mm}$ x 12” $\mathrm{AgX} 1.5 \mathrm{~m}$ SiComp probe.

X-ray was conducted using a Bruker D8 diffractometer with APEX2 detector. The crystal was kept at a steady $T=100(2) \mathrm{K}$ during data collection. The structure was solved with the ShelXT 
(Sheldrick, 2015) structure solution program using the Intrinsic Phasing solution method and by using Olex2 (Dolomanov et al., 2009) as the graphical interface. The model was refined with version 2018/3 of ShelXL (Sheldrick, 2015) using Least Squares minimization.

Ultra-high performance liquid chromatography (UPLC) was performed on a Waters ACQUITY UPLC H-Class System with an ACQUITY QDa detector.

\section{Acquisition and Preparation of Compounds}

The following substrates and reagents were purchased from commercial sources (SigmaAldrich, Alfa-Aesar, Strem Chemicals, Oakwood Chemical and TCI America) and used directly without further purification (unless otherwise stated):

copper(I) iodide, copper(0) powder, copper(I) bromide, copper(II) bromide, copper(I) oxide, copper(I) triflate, copper(II) triflate, copper(II) acetate, copper(II) acetate monohydrate, pyridine (anhydrous), 2,6-di-tert-butylpyridine, triethylamine, Silica (SiliaFlash ${ }^{\circledR}$ P60, 40-63 $\mu \mathrm{m}$ ), bromobenzene, oxalyl dichloride, aluminum chloride, 2,2,2-trichloroethanol, 2,2,2trifluoroethanol, 2,2,2-tribromoethanol, concentrated hydrogen chloride aqueous solution, hydrazine hydrate (50-60\%), anisole, 2-(4-bromophenyl)-2-oxoacetic acid, tert-butylbenzene, benzene, isatin, 1-methylisatin, 1,2-bis(4-bromophenyl)ethane-1,2-dione, ethyl 2-oxo-4phenylbutanoate, ethyl 4-nitrophenylglyoxylate, ethyl 2-chloro-5-pyridylglyoxylate, ethyl phenylglyoxylate, ethyl 2-(4-(tert-butyl)phenyl)-2-oxoacetate, ethyl 2-(4-methoxyphenyl)-2oxoacetate, ethyl 2-oxo-2-(4-(trifluoromethyl)phenyl)acetate, benzoic acid, 1,2-dichloroethane $\mathrm{N}, \mathrm{N}$-dimethylpyridin-4-amine, 4-methoxypyridine, 4-methylpyridine, 4-phenylpyridine, 4trifluoromethylpyridine, 4-cyanopyridine, 4-(pyrrolidin-1-yl)pyridine, benzophenone imine, propylene carbonate, $\mathrm{Cu}(\mathrm{II})$ trifluoroacetate hydrate 4-(piperidin-1-yl)pyridine, 4-(pyridin-4yl)morpholine, 5,6,9,10-tetrahydro- $4 \boldsymbol{H}, 8 \boldsymbol{H}$-pyrido[3,2,1-ij] [1,6]naphthyridine, phenyl(pyridin-2yl)methanone, styrene.

\section{The following substrates were prepared following literature procedures:}

2,2,2-trichloroethyl (Z)-2-(4-bromophenyl)-2-hydrazineylideneacetate, ${ }^{1}$ 2,2,2-trichloroethyl (Z)2-(4-(tert-butyl)phenyl)-2-hydrazineylideneacetate, ${ }^{1}$ 2,2,2-trichloroethyl (Z)-2-hydrazineylidene- 
2-(4-methoxyphenyl)acetate, ${ }^{1}$ 2,2,2-trichloroethyl (Z)-2-hydrazineylidene-2-phenylacetate, ${ }^{1}$ ethyl (Z)-2-(4-bromophenyl)-2-hydrazineylideneacetate, ${ }^{2}$ ethyl (Z)-2-hydrazineylidene-2phenylacetate, ${ }^{2}$ ethyl (Z)-2-hydrazineylidene-2-(4-methoxyphenyl)acetate, ${ }^{2}$ ethyl (E)-2hydrazineylidene-4-phenylbutanoate, ${ }^{2}$ 1,2-bis(4-bromophenyl)-2-hydrazineylideneethan-1-one, ${ }^{3}$ (E)-3-hydrazineylideneindolin-2-one, ${ }^{2} \quad$ (Z)-3-hydrazineylideneindolin-2-one, ${ }^{2} \quad$ (E)-3hydrazineylidene-1-methylindolin-2-one, ${ }^{2} \quad$ (Z)-3-hydrazineylidene-1-methylindolin-2-one, ${ }^{2}$

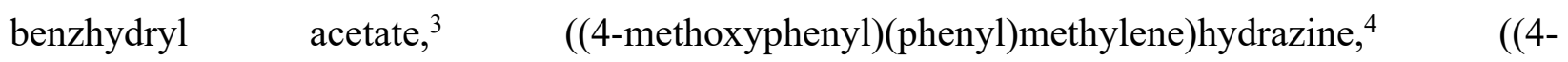
nitrophenyl)(phenyl)methylene)hydrazine, ${ }^{4} \quad$ ((4-methoxyphenyl)(phenyl)methylene)hydrazine, ${ }^{4}$ ((2-cloro-4-nitrophenyl)(phenyl)methylene)hydrazine, ${ }^{4}$ ((4-nitrophenyl)(4methoxyphenyl)methylene)hydrazine, ${ }^{4} \mathrm{Rh}(R-p-\mathrm{Ph}-\mathrm{TPCP}) 4{ }_{4}{ }^{5} \mathrm{Rh}(S$-PTAD $) 4 .{ }^{6}$

\section{Synthesis for Starting Materials}

The synthesis for trifluoroethyl and tribromoethyl derivatives were shown as below.

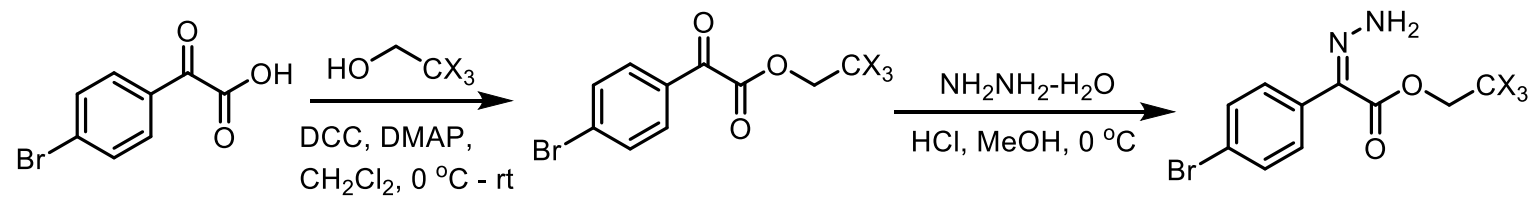

A dry $100 \mathrm{~mL}$ round-bottom flask was charged with 2-(4-bromophenyl)-2-oxoacetic acid ${ }^{212}$ (1.15 g, $5 \mathrm{mmol}, 1.0$ equiv), DMAP (61.1 mg, $0.5 \mathrm{mmol}, 0.1$ equiv) and 2,2,2-trihaloethanol (6 mmol, 1.2 equiv). After the flask was flushed with argon gas (3 times), $10 \mathrm{~mL}$ of dry dichloromethane was added to the mixture. Then, the reaction mixture was cooled to $0{ }^{\circ} \mathrm{C}$ via ice bath. The solution of DCC (1.13 g, $5.5 \mathrm{mmol}, 1.1$ equiv) in $8 \mathrm{~mL}$ of dry dichloromethane was then added slowly at 0 ${ }^{\circ} \mathrm{C}$. The reaction mixture was stirred for 15 hours, at which point it was warmed up to room temperature $\left(23^{\circ} \mathrm{C}\right)$. The reacted mixture was filtered through Celite ${ }^{\circledR}$ under reduced pressure and washed with dichloromethane. The filtrate was collected and concentrated under reduced pressure. The crude compound was purified by flash column chromatography (0-6\% ethyl acetate in hexane) to afford slightly yellow oil in $55-70 \%$ yield. The product was used immediately in the next step. A $250 \mathrm{~mL}$ round-bottom flask was charged with hydrazine monohydrate $(50-60 \% \mathrm{w} / \mathrm{w}, 1.7 \mathrm{~mL}$, $30 \mathrm{mmol}, 10$ equiv) and $\mathrm{MeOH}(45 \mathrm{~mL})$. After flushed with argon, the reaction mixture was cooled to $0^{\circ} \mathrm{C}$ via ice bath. To this solution, aqueous $\mathrm{HCl}(3.0 \mathrm{M}, 10.0 \mathrm{~mL}, 30 \mathrm{mmol}, 10$ equiv) was added 
slowly, followed by addition of 2,2,2-trihaloethyl 2-(4-bromophenyl)-2-oxoacetate (3.0 mmol, 1.0 equiv) in $\mathrm{MeOH}(3 \mathrm{~mL})$ dropwise over about $5 \mathrm{~min}$. The reaction mixture was stirred at $0{ }^{\circ} \mathrm{C}$ until full consumption of starting material was observed by TLC control (normally 6-8 h, unnecessary longer reaction times lead to significantly lower yields). The reaction mixture was quenched by the addition of sat. $\mathrm{NaHCO}_{3}(100 \mathrm{~mL}), \mathrm{MeOH}$ was evaporated under reduced pressure, the residue was extracted with ethyl acetate $(100 \mathrm{~mL}$ x 3). The organic layers were washed with brine (100 $\mathrm{mL}$ ) and concentrated. The residue was purified by flash column chromatography (2-5\% ethyl acetate in hexane for $Z$-isomer and $15-25 \%$ for $E$-isomer if needed).<smiles>O=C(OCC(F)(F)F)C(=O)c1ccc(Br)cc1</smiles>

\section{2,2,2-Trifluoroethyl 2-(4-bromophenyl)-2-oxoacetate}

It was obtained as slightly yellow oil in 58\% yield following the general procedure above using 2,2,2-trifluoroethan-1-ol $(0.45 \mathrm{~mL})$ as starting material.

$\mathbf{R f}=0.34(10 \%$ ethyl acetate/hexane $)$;

${ }^{1}$ H NMR $\left(600 \mathrm{MHz}, \mathrm{CDCl}_{3}\right) \delta 7.89(\mathrm{~d}, J=8.8 \mathrm{~Hz}, 2 \mathrm{H}), 7.70(\mathrm{~d}, J=8.7 \mathrm{~Hz}, 2 \mathrm{H}), 4.75(\mathrm{q}, J=8.2$ $\mathrm{Hz}, 2 \mathrm{H})$.

${ }^{13}$ C NMR $\left(151 \mathrm{MHz}, \mathrm{CDCl}_{3}\right) \delta 183.0,161.2,132.6,131.4,131.3,130.8,122.4(\mathrm{q}, J=277.3 \mathrm{~Hz})$, $61.2(\mathrm{q}, J=37.6 \mathrm{~Hz})$.

${ }^{19}$ F NMR (282 MHz, $\left.\mathrm{CDCl}_{3}\right) \delta$-73.40.

IR (neat) 3031, 2971, 1759, 1694, 1586, 1272, 1161, 1072, 1040, 1012, $978 \mathrm{~cm}^{-1}$.

HRMS (-p NSI) calcd for $\mathrm{C}_{10} \mathrm{H}_{6} \mathrm{BrF}_{3} \mathrm{O}_{3}(\mathrm{M})^{-} 309.9458$ found 309.9459 . 
<smiles>CC(C)(C)COC(=O)C(=O)c1ccc(Br)cc1</smiles>

\section{2,2,2-Tribromoethyl 2-(4-bromophenyl)-2-oxoacetate}

It was obtained as white solid in $69 \%$ yield following the general procedure above using 2,2,2tribromoethan-1-ol (1.7 g) as starting material.

mp: $63-65^{\circ} \mathrm{C} . \mathbf{R f}=0.60$ (20\% ethyl acetate/hexane).

${ }^{1} \mathbf{H}$ NMR (600 MHz, $\left.\mathbf{C D C l}_{3}\right) \boldsymbol{\delta} 7.97(\mathrm{~d}, J=8.8 \mathrm{~Hz}, 2 \mathrm{H}), 7.70(\mathrm{~d}, J=8.8 \mathrm{~Hz}, 2 \mathrm{H}), 5.22(\mathrm{~s}, 2 \mathrm{H})$.

${ }^{13}$ C NMR (151 MHz, CDCl 3 ) $\delta$ 183.5, 161.1, 132.5, 131.6, 131.1, 130.9, 77.5, 33.4.

IR (neat) 3091, 3000, 2949, 1748, 1689, 1586, 1188, 1164, 1070, 1000, $632 \mathrm{~cm}^{-1}$.

HRMS (-p NSI) calcd for $\mathrm{C}_{10} \mathrm{H}_{6} \mathrm{Br}_{5} \mathrm{O}_{3}(\mathrm{M}+\mathrm{Br})^{-} 568.6239$ found 568.6227.<smiles>N/N=C(\OCC(F)(F)F)C(=O)OCC(F)(F)F</smiles>

\section{2,2,2-Trifluoroethyl (Z)-2-(4-bromophenyl)-2-hydrazineylideneacetate}

It was obtained as white solid in 60\% yield following the general procedure above using 2,2,2trifluoroethyl 2-(4-bromophenyl)-2-oxoacetate (933 mg) as starting material.

mp: $63-65^{\circ} \mathrm{C} . \mathbf{R f}=0.40(20 \%$ ethyl acetate/hexane $)$.

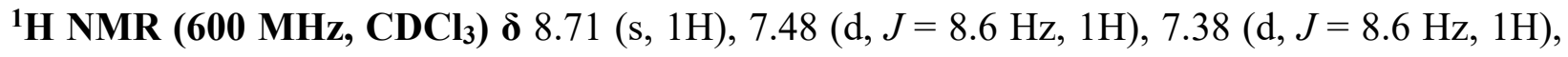
$4.61(\mathrm{q}, J=8.3 \mathrm{~Hz}, 1 \mathrm{H})$.

${ }^{13}$ C NMR (151 MHz, CDCl $\left._{3}\right) \delta$ 160.3, 134.8, 131.1, 129.8, 127.2, 122.8 (d, $J=277.4$ Hz), 121.9, $60.0(\mathrm{q}, J=36.9 \mathrm{~Hz})$.

${ }^{19}$ F NMR (282 MHz, $\left.\mathrm{CDCl}_{3}\right) \delta-73.20--73.40(\mathrm{~m})$.

IR (neat) 3466, 3260, 1703, 1568, 1511, 1488, 1287, 1249, 1136, 962, 830, $544 \mathrm{~cm}^{-1}$.

HRMS (+p APCI) calcd for $\mathrm{C}_{10} \mathrm{H}_{9} \mathrm{BrF}_{3} \mathrm{~N}_{2} \mathrm{O}_{2}(\mathrm{M}+\mathrm{H})^{+} 324.9794$ found 324.9789. 
<smiles>CC(C)(C)COC(=O)/C(=N\N)c1ccc(Br)cc1</smiles>

\section{2,2,2-Tribromoethyl (Z)-2-(4-bromophenyl)-2-hydrazineylideneacetate}

It was obtained as white solid in $78 \%$ yield following the general procedure above using 2,2,2tribromoethyl 2-(4-bromophenyl)-2-oxoacetate (1.48 g) as starting material.

mp: $86-88{ }^{\circ} \mathrm{C} . \mathbf{R f}=0.42(20 \%$ ethyl acetate/hexane $)$.

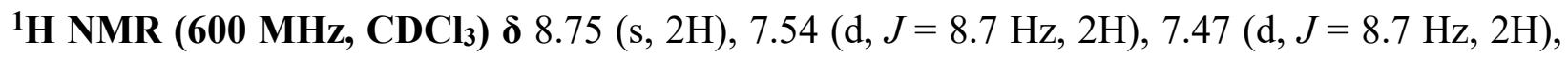
$5.09(\mathrm{~s}, 2 \mathrm{H})$.

${ }^{13}$ C NMR (151 MHz, CDCl $)$ ) $\delta$ 160.2, 134.8, 130.9, 130.3, 127.5, 121.8, 76.9, 34.6.

IR (neat) 3463, 3287, 2943, 1697, 1564, 1508, 1488, 1251, 1136, 1073, 829, 729, 631, $522 \mathrm{~cm}^{-1}$. HRMS (+p APCI) calcd for $\mathrm{C}_{10} \mathrm{H}_{9} \mathrm{Br}_{4} \mathrm{~N}_{4} \mathrm{O}_{2}(\mathrm{M}+\mathrm{H})^{+} 504.7392$ found 504.7388.<smiles>CC(C)(C)COC(=O)/C(=N/N)c1ccc(Br)cc1</smiles>

\section{2,2,2-Tribromoethyl (E)-2-(4-bromophenyl)-2-hydrazineylideneacetate}

It was obtained as white solid in 16\% yield following the general procedure above using 2,2,2tribromoethyl 2-(4-bromophenyl)-2-oxoacetate (1.48 g) as starting material.

mp: $129-131{ }^{\circ} \mathrm{C} . \mathbf{R f}=0.14(20 \%$ ethyl acetate/hexane $)$.

${ }^{1}$ H NMR (600 MHz, CDCl $)$ $) 7.65$ (d, $\left.J=8.5 \mathrm{~Hz}, 2 \mathrm{H}\right), 7.25$ (d, J=9.1 Hz, 3H), 6.49 (s, 2H), $5.06(\mathrm{~s}, 2 \mathrm{H})$.

${ }^{13}$ C NMR (151 MHz, $\left.\mathbf{C D C l}_{3}\right) \boldsymbol{\delta}$ 162.0, 134.5, 132.6, 130.8, 127.8, 123.9, 35.7 (The signal for $\mathrm{CBr}_{3}$ was buried under the $\mathrm{CDCl}_{3}$ peaks).

IR (neat) 3409, 3288, 3209, 2940, 1716, 1553, 1484, 1368, 1311, 1126, 1073, 1010, 728, 631, $499 \mathrm{~cm}^{-1}$.

HRMS (+p APCI) calcd for $\mathrm{C}_{10} \mathrm{H}_{9} \mathrm{Br}_{4} \mathrm{~N}_{4} \mathrm{O}_{2}(\mathrm{M}+\mathrm{H})^{+} 504.7392$ found 504.7384 . 
The other hydrazones with ethyl ester were synthesized following the procedures adapted from literature: ${ }^{2}$

A $100 \mathrm{~mL}$ round-bottom flask was charged with ethyl 2-aryl-2-oxoacetate (5 mmol, 1 equiv) and benzoic acid (611 mg, $5 \mathrm{mmol}, 1$ equiv). After flushed with argon, tetrahydrofuran $(15 \mathrm{~mL})$ was added, followed by the addition of hydrazine monohydrate $(50-60 \% \mathrm{w} / \mathrm{w}, 0.28 \mathrm{~mL}, 5 \mathrm{mmol}, 1$ equiv) slowly. The reaction mixture was stirred at room temperature $\left(23^{\circ} \mathrm{C}\right)$ until full consumption of starting material was observed by TLC control (or disappearance of the visible precipitate). The reaction mixture was quenched by the addition of sat. $\mathrm{NaHCO}_{3}(10 \mathrm{~mL})$, then, the resulted mixture was extracted with ethyl acetate $(30 \mathrm{~mL} \times 3)$. The organic layers were washed with brine $(30 \mathrm{~mL})$ and concentrated. The residue was purified by flash column chromatography as light yellow solid or oil (5-10\% ethyl acetate in hexane for $Z$-isomer and $15-30 \%$ for $E$-isomer if needed).<smiles>CCOC(=O)C(=NN)c1ccc([N+](=O)[O-])cc1</smiles>

\section{Ethyl (Z)-2-hydrazineylidene-2-(4-nitrophenyl)acetate}

It was obtained as light yellow solid in 37\% yield following the general procedure above using ethyl 2-(4-nitrophenyl)-2-oxoacetate ( $1.0 \mathrm{~g}$ ) as starting material. (40\% yield of the $E$-isomer) mp: $96-98{ }^{\circ} \mathrm{C} . \mathbf{R f}=0.29$ (20\% ethyl acetate in hexane) .

${ }^{1} \mathbf{H}$ NMR (600 MHz, $\left.\mathbf{C D C l}_{3}\right) \boldsymbol{\delta} 8.82(\mathrm{~s}, 2 \mathrm{H}), 8.18(\mathrm{~d}, J=9.1 \mathrm{~Hz}, 2 \mathrm{H}), 7.73(\mathrm{~d}, J=9.1 \mathrm{~Hz}, 2 \mathrm{H})$, $4.35(\mathrm{q}, J=7.1 \mathrm{~Hz}, 2 \mathrm{H}), 1.35(\mathrm{t}, J=7.1 \mathrm{~Hz}, 3 \mathrm{H})$.

${ }^{13}$ C NMR (151 MHz, $\left.\mathbf{C D C l}_{3}\right) \boldsymbol{\delta}$ 162.4, 146.7, 143.1, 128.7, 127.8, 123.1, 61.1, 14.2.

IR (neat) 3462, 3272, 2984, 2904, 1680, 1593, 1561, 1510, 1485, 1328, 1263, 1189, 1163, 1121, 1109, 1023, 990, 857, 838, 796, 752, 711, 697, 517, $491 \mathrm{~cm}^{-1}$.

FTMS (+p NSI) calcd for $\mathrm{C}_{10} \mathrm{H}_{12} \mathrm{~N}_{3} \mathrm{O}_{4}(\mathrm{M}+\mathrm{H})^{+} 238.0822$ found 238.08193 . 
<smiles>CCOC(=O)/C(=N/N)c1ccc(F)cc1</smiles>

\section{Ethyl (E)-2-hydrazineylidene-2-(4-(trifluoromethyl)phenyl)acetate}

It was obtained as light yellow solid in $20 \%$ yield following the general procedure above using ethyl 2-(4-trifluoromethylphenyl)-2-oxoacetate $(1.0 \mathrm{~g})$ as starting material. (20\% yield of the Zisomer)

mp: $111-116^{\circ} \mathrm{C} . \mathbf{R f}=0.08(20 \%$ ethyl acetate in hexane $)$.

${ }^{1}$ H NMR (400 MHz, CDCl $\mathbf{l}_{3} \boldsymbol{\delta} 7.74(\mathrm{~d}, J=8.0 \mathrm{~Hz}, 2 \mathrm{H}), 7.44(\mathrm{~d}, J=7.5 \mathrm{~Hz}, 2 \mathrm{H}), 6.34(\mathrm{~s}, 2 \mathrm{H})$, $4.29(\mathrm{q}, J=7.1 \mathrm{~Hz}, 2 \mathrm{H}), 1.31(\mathrm{t}, J=7.1 \mathrm{~Hz}, 3 \mathrm{H})$.

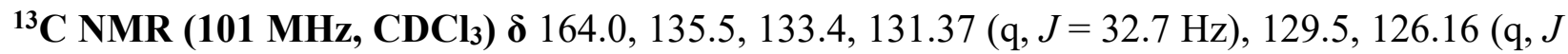
$=3.8 \mathrm{~Hz}), 123.75(\mathrm{q}, J=272.3 \mathrm{~Hz}), 61.5,14.3$.

${ }^{19}$ F NMR (376 MHz, $\left.\mathrm{CDCl}_{3}\right) \delta-62.98$.

IR (neat) 3413, 3289, 2986, 1704, 1616, 1567, 1514, 1397, 1373, 1322, 1229, 1105, 1066, 1043, $1017,1000,870,849,839,815,776,742,710,683,611,583,493 \mathrm{~cm}^{-1}$.

FTMS (+p NSI) calcd for $\mathrm{C}_{11} \mathrm{H}_{12} \mathrm{~F}_{3} \mathrm{~N}_{2} \mathrm{O}_{2}(\mathrm{M}+\mathrm{H})^{+} 261.0845$ found 261.08416 .

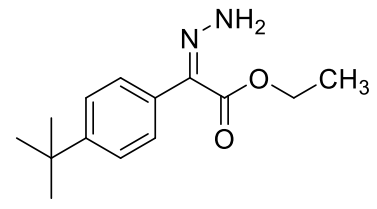

\section{Ethyl (Z)-2-(4-(tert-butyl)phenyl)-2-hydrazineylideneacetate}

It was obtained as yellow oil in 67\% yield following the general procedure above using ethyl 2(4-tert-butylphenyl)-2-oxoacetate (1.0 g) as starting material.

$\mathbf{R f}=0.63(20 \%$ ethyl acetate in hexane $)$.

${ }^{1}$ H NMR (400 MHz, CDCl $\mathbf{l}_{3} \boldsymbol{\delta} 8.35(\mathrm{~s}, 2 \mathrm{H}), 7.46(\mathrm{~d}, J=8.8 \mathrm{~Hz}, 2 \mathrm{H}), 7.36(\mathrm{~d}, J=8.7 \mathrm{~Hz}, 2 \mathrm{H})$, $4.32(\mathrm{q}, J=7.1 \mathrm{~Hz}, 2 \mathrm{H}), 1.39-1.28(\mathrm{~m}, 12 \mathrm{H})$.

${ }^{13}$ C NMR (101 MHz, CDCl 3$) \delta$ 163.0, 150.5, 133.8, 131.4, 127.7, 124.9, 60.7, 34.6, 31.3, 14.2;

IR (neat) 3455, 3284, 2961, 2904, 2868, 1666, 1564, 1511, 1463, 1392, 1367, 1317, 1291, 1261, $1146,1109,1021,993,836,792,723,585,547,486 \mathrm{~cm}^{-1}$.

FTMS (+p NSI) calcd for $\mathrm{C}_{14} \mathrm{H}_{21} \mathrm{~N}_{2} \mathrm{O}_{2}(\mathrm{M}+\mathrm{H})^{+} 249.1598$ found 249.15933 . 


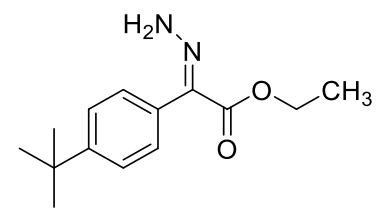

\section{Ethyl (E)-2-(4-(tert-butyl)phenyl)-2-hydrazineylideneacetate}

It was obtained as white solid in $22 \%$ yield following the general procedure above using ethyl 2(4-tert-butylphenyl)-2-oxoacetate (1.0 g) as starting material.

mp: $65-67^{\circ} \mathrm{C} . \mathbf{R f}=0.19(20 \%$ ethyl acetate in hexane $)$.

${ }^{1}$ H NMR (400 MHz, CDCl 3$) \boldsymbol{\delta} 7.45(\mathrm{~d}, J=8.3 \mathrm{~Hz}, 2 \mathrm{H}), 7.20(\mathrm{~d}, J=8.3 \mathrm{~Hz}, 2 \mathrm{H}), 6.32$ (s, 2H), $4.25(\mathrm{q}, J=7.2 \mathrm{~Hz}, 2 \mathrm{H}), 1.30(\mathrm{~d}, J=2.3 \mathrm{~Hz}, 12 \mathrm{H})$.

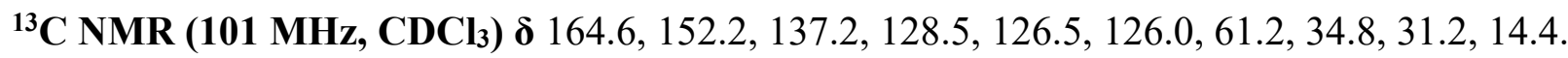
IR (neat) 3409, 3291, 3209, 2969, 2868, 1737, 1705, 1610, 1564, 1506, 1463, 1367, 1326, 1307, $1268,1227,1171,1135,1106,1045,1018,999,910,867,841,820,777,757,726,645,528 \mathrm{~cm}^{-}$ 1 .

FTMS (+p NSI) calcd for $\mathrm{C}_{14} \mathrm{H}_{21} \mathrm{~N}_{2} \mathrm{O}_{2}(\mathrm{M}+\mathrm{H})^{+} 249.1598$ found 249.15934 .<smiles>CCOC(=O)/C(=N\N)c1ccc(Cl)nc1</smiles>

\section{Ethyl (Z)-2-(6-chloropyridin-3-yl)-2-hydrazineylideneacetate}

It was obtained as light yellow solid in $21 \%$ yield following the general procedure above using ethyl 2-(6-chloropyridin-3-yl)-2-oxoacetate (1.1 g) as starting material.

mp: $93-95{ }^{\circ} \mathrm{C} . \mathbf{R f}=0.32(20 \%$ ethyl acetate in hexane) .

${ }^{1}$ H NMR (600 MHz, CDCl $\mathbf{~ M ~}_{3} 8.80$ (s, 2H), $8.57(\mathrm{dd}, J=2.5,0.7 \mathrm{~Hz}, 1 \mathrm{H}), 7.82(\mathrm{dd}, J=8.3,2.5$ $\mathrm{Hz}, 1 \mathrm{H}), 7.30-7.26(\mathrm{~m}, 1 \mathrm{H}), 4.32$ (q, $J=7.1 \mathrm{~Hz}, 2 \mathrm{H}), 1.34$ (t, $J=7.1 \mathrm{~Hz}, 3 \mathrm{H})$.

${ }^{13}$ C NMR (151 MHz, CDCl 3$) \delta$ 162.3, 149.8, 149.2, 138.2, 131.6, 125.8, 123.3, 61.0, 14.1.

IR (neat) 3380, 3227, 2988, 1689, 1579, 1556, 1506, 1454, 1280, 1170, 1143, 1108, 1021, 830, $529,504 \mathrm{~cm}^{-1}$.

FTMS (+p NSI) calcd for $\mathrm{C}_{9} \mathrm{H}_{11} \mathrm{ClN}_{3} \mathrm{O}_{2}(\mathrm{M}+\mathrm{H})^{+} 228.0534$ found 228.05319 . 
<smiles>CCOC(=O)/C(=N/N)c1ccc(Cl)nc1</smiles>

\section{Ethyl (E)-2-(6-chloropyridin-3-yl)-2-hydrazineylideneacetate}

It was obtained as light yellow solid in 53\% yield following the general procedure above using ethyl 2-(6-chloropyridin-3-yl)-2-oxoacetate (1.1 g) as starting material.

mp: $102-104{ }^{\circ} \mathrm{C} . \mathbf{R f}=0.04(20 \%$ ethyl acetate in hexane $)$.

${ }^{1}$ H NMR (600 MHz, $\left.\mathbf{C D C l}_{3}\right) \boldsymbol{\delta} 8.37(\mathrm{dd}, J=2.4,0.8 \mathrm{~Hz}, 1 \mathrm{H}), 7.65(\mathrm{dd}, J=8.2,2.4 \mathrm{~Hz}, 1 \mathrm{H}), 7.47$

$(\mathrm{dd}, J=8.2,0.8 \mathrm{~Hz}, 1 \mathrm{H}), 6.40(\mathrm{~s}, 2 \mathrm{H}), 4.31$ (q, $J=7.1 \mathrm{~Hz}, 2 \mathrm{H}), 1.34$ (t, $J=7.1 \mathrm{~Hz}, 3 \mathrm{H})$.

${ }^{13}$ C NMR (151 MHz, CDCl $)$ d 163.8, 152.3, 149.9, 139.8, 132.7, 124.9, 124.6, 61.7, 14.3.

IR (neat) 3401, 3293, 3213, 2982, 1698, 1551, 1458, 1372, 1307, 1235, 1137, 1104, $1050 \mathrm{~cm}^{-1}$. FTMS (+p NSI) calcd for $\mathrm{C}_{9} \mathrm{H}_{11} \mathrm{ClN}_{3} \mathrm{O}_{2}(\mathrm{M}+\mathrm{H})^{+} 228.0534$ found 228.05315 . 


\section{Hydrazone Oxidation and Product Characterization}

*Unoptimized reactions were following the same procedure with variations as indicated in tables.

*Reactions under air was conducted in vials open to air (no septum).

A $20 \mathrm{~mL}$ scintillation vial equipped with stir bar (bigger size, egg shape) was charged with $\mathrm{Cu}(\mathrm{OAc})_{2}-\mathrm{H}_{2} \mathrm{O}\left(10 \mathrm{mg}, 0.05 \mathrm{mmol}, 10 \mathrm{~mol} \%\right.$ ), silica powder (100 mg, SiliaFlash ${ }^{\circledR}$ P60, 40-63 $\mu \mathrm{m}$ ) and $2 \mathrm{~mL}$ solution of $0.5 \%$ pyridine in dichloromethane. The reaction vessel with a $14 / 20$ septum was flushed with $\mathrm{O}_{2}$ and the $\mathrm{O}_{2}$ balloon (double layered) was left on the septum. Another $2.2 \mathrm{~mL}$ solution of $0.5 \%$ pyridine in dichloromethane was added, and the initial mixture was stirred vigorously (600 rpm) for $5 \mathrm{~min}$. A solution of corresponding hydrazone ( $0.5 \mathrm{mmol}, 1.0$ equiv) in $1 \mathrm{~mL}$ of $0.5 \%$ pyridine /dichloromethane was added in one portion, and the reaction mixture was stirred for $1 \mathrm{~h}$ at room temperature $\left(23^{\circ} \mathrm{C}\right)$. After allowed time passed, the resulted mixture was filtered through a short pipet of silica $(0.9 \mathrm{~cm}$ diameter, $5 \mathrm{~cm}$ height $)$ and concentrated for crude ${ }^{1} \mathrm{H}$ NMR. Further purification was conducted using flash column chromatography (0-3\% diethyl ether in hexane).

Scheme S1. Full Substrate Scope using $\mathrm{O}_{2} /$ air.

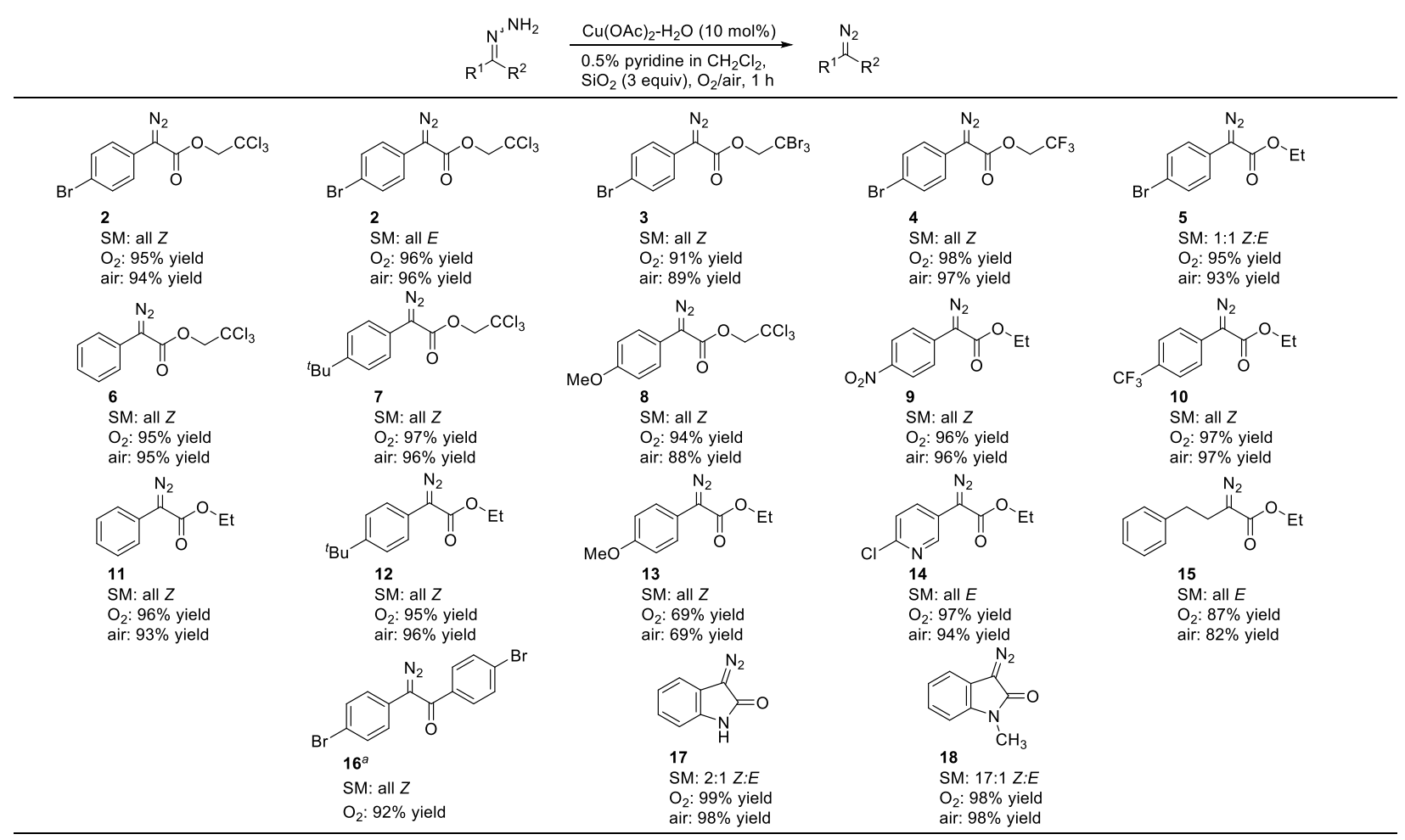

${ }^{a}$ Reaction was conducted using $2 \%$ pyridine in DCM under dark condition with alumium foil. 
<smiles>N#CC(=O)OCC(Cl)(Cl)Cl</smiles>

\section{2,2,2-Trichloroethyl 2-(4-bromophenyl)-2-diazoacetate (2)}

It was obtained as yellow solid in 95\% yield following general procedure above using 2,2,2trifluoroethyl (Z)-2-(4-bromophenyl)-2-hydrazineylideneacetate (187 $\mathrm{mg})$ as starting material. The NMR data are consistent with literature values. ${ }^{8}$

${ }^{1}$ H NMR (600 MHz, CDCl $)$ 反 $7.52(\mathrm{~d}, J=8.7 \mathrm{~Hz}, 2 \mathrm{H}), 7.37$ (d, $\left.J=8.7 \mathrm{~Hz}, 2 \mathrm{H}\right), 4.91(\mathrm{~s}, 2 \mathrm{H})$;

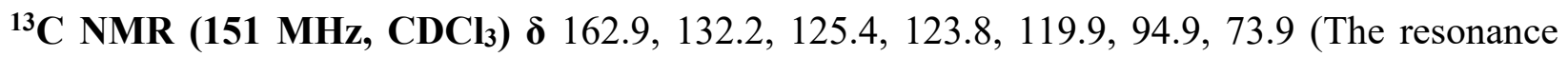
resulting from the diazo carbon was not observed).<smiles>CC(C)(C)COC(=O)C#N</smiles>

\section{2,2,2-Tribromoethyl 2-(4-bromophenyl)-2-diazoacetate (3)}

It was obtained as yellow solid in 91\% yield following general procedure above using 2,2,2tribromoethyl (Z)-2-(4-bromophenyl)-2-hydrazineylideneacetate (254 $\mathrm{mg}$ ) as starting material. The NMR data are consistent with literature values. ${ }^{9}$

${ }^{1}$ H NMR (600 MHz, CDCl $)$ ) $7.53(\mathrm{~d}, J=8.8 \mathrm{~Hz}, 1 \mathrm{H}), 7.40(\mathrm{~d}, J=8.8 \mathrm{~Hz}, 1 \mathrm{H}), 5.09$ (s, 1H);

${ }^{13} \mathbf{C}$ NMR (151 MHz, $\mathbf{C D C l}_{3}$ ) $\delta$ 162.8, 132.2, 125.4, 123.9, 119.9, 78.3, 35.7 (The resonance resulting from the diazo carbon was not observed). 
<smiles>N#CC(=O)OCC(F)(F)F</smiles>

\section{2,2,2-Trioroethyl 2-(4-bromophenyl)-2-diazoacetate (4)}

It was obtained as yellow solid in 98\% yield following general procedure above using 2,2,2trifluoroethyl (Z)-2-(4-bromophenyl)-2-hydrazineylideneacetate (163 mg) as starting material. The NMR data are consistent with literature values. ${ }^{9}$

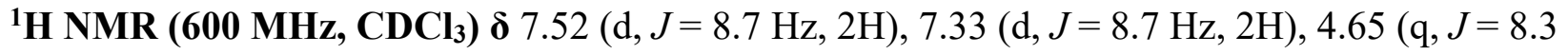
$\mathrm{Hz}, 2 \mathrm{H})$.

${ }^{13}$ C NMR (151 MHz, $\left.\mathbf{C D C l}_{3}\right) \delta$ 162.8, 132.2, 125.4, 123.7, 122.9 (q, $\left.J=277.5 \mathrm{~Hz}\right), 120.0,60.4$ (q, $J=37.0 \mathrm{~Hz}$ ) (The resonance resulting from the diazo carbon was not observed).<smiles>CCOC(=O)C(=N)c1ccc(Br)cc1</smiles>

\section{Ethyl 2-(4-bromophenyl)-2-diazoacetate (5)}

It was obtained as yellow solid in 95\% yield following general procedure above using ethyl 2-(4bromophenyl)-2-hydrazineylideneacetate $(1: 1 E: Z, 135.6 \mathrm{mg})$ as starting material. The NMR data are consistent with literature values. ${ }^{10}$

${ }^{1}$ H NMR (600 MHz, $\left.\mathbf{C D C l}_{3}\right) \boldsymbol{\delta} 7.49(\mathrm{~d}, J=8.9 \mathrm{~Hz}, 1 \mathrm{H}), 7.36(\mathrm{~d}, J=8.7 \mathrm{~Hz}, 1 \mathrm{H}), 4.33$ (q, $J=7.1$ $\mathrm{Hz}, 1 \mathrm{H}), 1.34$ (t, $J=7.1 \mathrm{~Hz}, 2 \mathrm{H})$.

${ }^{13} \mathbf{C}$ NMR (151 MHz, $\left.\mathbf{C D C l}_{3}\right) \boldsymbol{\delta}$ 164.8, 132.0, 132.0, 125.3, 125.3, 124.9, 124.9, 119.3, 119.2, 61.2, $61.2,14.5,14.5$ (The resonance resulting from the diazo carbon was not observed). 
<smiles>N#CC(=O)C(=O)OCC(Cl)(Cl)Cl</smiles>

\section{2,2,2-Trichloroethyl 2-diazo-2-phenylacetate (6)}

It was obtained as yellow solid in 95\% yield following general procedure above using 2,2,2trichloroethyl (Z)-2-hydrazineylidene-2-phenylacetate $(148 \mathrm{mg})$ as starting material. The NMR data are consistent with literature values. ${ }^{11}$

${ }^{1}$ H NMR (600 MHz, $\left.\mathbf{C D C l}_{3}\right) \boldsymbol{\delta} 7.53-7.48(\mathrm{~m}, 2 \mathrm{H}), 7.45-7.38(\mathrm{~m}, 2 \mathrm{H}), 7.25-7.21$ (m, 1H), $4.92(\mathrm{~s}, 2 \mathrm{H})$.

${ }^{13} \mathbf{C}$ NMR (151 MHz, $\mathbf{C D C l}_{3}$ ) $\delta$ 163.3, 129.1, 126.3, 124.6, 124.1, 95.0, 73.8 (The resonance resulting from the diazo carbon was not observed).<smiles>CC(C)(C)c1ccc(C(=N)C(=O)OCC(Cl)(Cl)Cl)cc1</smiles>

\section{2,2,2-trichloroethyl 2-(4-(tert-butyl)phenyl)-2-diazoacetate (7)}

It was obtained as yellow solid in 97\% yield following general procedure above using 2,2,2trichloroethyl (Z)-2-(4-(tert-butyl)phenyl)-2-hydrazineylideneacetate (176 mg) as starting material. The NMR data are consistent with literature values. ${ }^{9}$

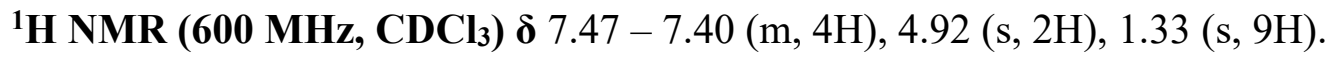

${ }^{13}$ C NMR (151 MHz, $\mathbf{C D C l}_{3}$ ) $\delta$ 149.6, 126.1, 124.1, 121.3, 95.1, 73.8, 34.5, 31.2 (The resonance resulting from the diazo carbon was not observed). 
<smiles>COc1ccc(C(=N)C(=O)OCC(Cl)(Cl)Cl)cc1</smiles>

\section{2,2,2-Trichloroethyl 2-diazo-2-(4-methoxyphenyl)acetate (8)}

It was obtained as yellow solid in 94\% yield following general procedure above using 2,2,2trichloroethyl (Z)-2-hydrazineylidene-2-(4-methoxyphenyl)acetate (163 mg) as starting material. The NMR data are consistent with literature values. ${ }^{9}$

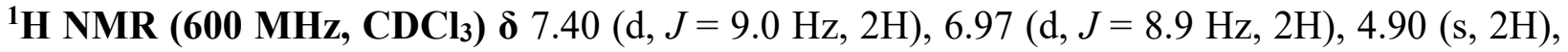
$3.82(\mathrm{~s}, 3 \mathrm{H})$.

${ }^{13}$ C NMR (151 MHz, $\left.\mathbf{C D C l}_{3}\right) \boldsymbol{\delta}$ 158.4, 126.1, 116.0, 114.7, 95.1, 73.9, 55.4 (The resonance resulting from the diazo carbon was not observed).<smiles>CCOC(=O)C(C#N)c1ccc([N+](=O)[O-])cc1</smiles>

\section{Ethyl 2-diazo-2-(4-nitrophenyl)acetate (9)}

It was obtained as yellow solid in 96\% yield following general procedure above using ethyl (Z)-2hydrazineylidene-2-(4-nitrophenyl)acetate $(119 \mathrm{mg})$ as starting material. The NMR data are consistent with literature values. ${ }^{12}$

${ }^{1}$ H NMR (400 MHz, $\left.\mathbf{C D C l}_{3}\right) \boldsymbol{\delta} 8.22(\mathrm{~d}, J=9.2 \mathrm{~Hz}, 2 \mathrm{H}), 7.66(\mathrm{~d}, J=9.2 \mathrm{~Hz}, 2 \mathrm{H}), 4.37$ (q, $J=7.1$ $\mathrm{Hz}, 2 \mathrm{H}), 1.36(\mathrm{t}, J=7.1 \mathrm{~Hz}, 3 \mathrm{H})$.

${ }^{13}$ C NMR (101 MHz, $\mathbf{C D C l}_{3}$ ) $\delta$ 163.7, 145.0, 134.0, 124.3, 123.1, 61.6, 14.4 (The resonance resulting from the diazo carbon was not observed). 
<smiles>CCOC(=O)C(=N)c1ccc(C(F)(F)F)cc1</smiles>

\section{Ethyl 2-diazo-2-(4-trifluoromethylphenyl)acetate (10)}

It was obtained as yellow solid in 97\% yield following general procedure above using ethyl $(E)$ 2-hydrazineylidene-2-(4-trifluoromethylphenyl)acetate $(130 \mathrm{mg}$ ) as starting material. The NMR data are consistent with literature values. ${ }^{13}$

${ }^{1}$ H NMR (400 MHz, CDCl $)$ ס 7.61 (s, 4H), 4.35 (q, $\left.J=6.9 \mathrm{~Hz}, 2 \mathrm{H}\right), 1.36$ (t, $\left.J=7.3 \mathrm{~Hz}, 3 \mathrm{H}\right)$.

${ }^{13}$ C NMR (101 MHz, CDCl $\left.)_{3}\right) \delta 164.4,130.2,127.5$ (q, $\left.J=32.7 \mathrm{~Hz}\right), 125.8(\mathrm{q}, J=3.9 \mathrm{~Hz}), 124.1$ (q, $J=271.7 \mathrm{~Hz}$ ), 123.4, 61.3, 14.5 (The resonance resulting from the diazo carbon was not observed).

${ }^{19}$ F NMR (376 MHz, $\left.\mathrm{CDCl}_{3}\right) \delta-62.47$.

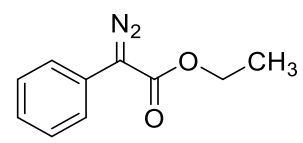

\section{Ethyl 2-diazo-2-phenylacetate (11)}

It was obtained as yellow solid in 96\% yield following general procedure above using ethyl (Z)-2-

hydrazineylidene-2-phenylacetate $(96 \mathrm{mg}$ ) as starting material. The NMR data are consistent with literature values. ${ }^{13}$

${ }^{1}$ H NMR (400 MHz, $\left.\mathbf{C D C l}_{3}\right) \boldsymbol{\delta} 7.49$ (d, $\left.J=7.7 \mathrm{~Hz}, 2 \mathrm{H}\right), 7.38(\mathrm{t}, J=7.7 \mathrm{~Hz}, 2 \mathrm{H}), 7.18$ (t, $J=7.4$ $\mathrm{Hz}, 1 \mathrm{H}), 4.34$ (q, $J=7.1 \mathrm{~Hz}, 2 \mathrm{H}), 1.35$ (t, $J=7.3 \mathrm{~Hz}, 3 \mathrm{H})$.

${ }^{13}$ C NMR (101 MHz, $\mathbf{C D C l}_{3}$ ) $\delta$ 165.2, 128.9, 125.8, 125.7, 124.0, 61.0, 14.5 (The resonance resulting from the diazo carbon was not observed). 
<smiles>CCOC(=O)C(=N)c1ccc(C(C)(C)C)cc1</smiles>

\section{Ethyl 2-diazo-2-(4-tert-butylphenyl)acetate (12)}

It was obtained as yellow solid in 95\% yield following general procedure above using ethyl (Z)-2hydrazineylidene-2-(4-tert-butylphenyl)acetate (124 mg) as starting material.

mp: $74-76^{\circ} \mathrm{C} . \mathbf{R f}=0.74(20 \%$ ethyl acetate/hexane $)$.

${ }^{1}$ H NMR (400 MHz, CDCl 3 ) $\boldsymbol{\delta} 7.41$ (s, 4H), 4.33 (q, $\left.J=7.1 \mathrm{~Hz}, 2 \mathrm{H}\right), 1.43-1.25$ (m, 12H).

${ }^{13}$ C NMR (101 MHz, CDCl $) \boldsymbol{\delta}$ 165.5, 149.0, 125.9, 124.0, 122.3, 60.9, 34.5, 31.3, 14.5 (The resonance resulting from the diazo carbon was not observed).

IR (neat) 2962, 2107,1696, 1518, 1392, 1370, 1338, 1242, 1168, 1112, 1050, 815, 740, $557 \mathrm{~cm}^{-1}$. HRMS (+p NSI) calcd for $\mathrm{C}_{14} \mathrm{H}_{18} \mathrm{BN}_{2} \mathrm{O}_{2} \mathrm{Na}(\mathrm{M}+\mathrm{Na})^{+} 269.1260$ found 269.12566 .<smiles>CCOC(=O)C(=N)c1ccc(OC)cc1</smiles>

\section{Ethyl 2-diazo-2-(4-methoxyphenyl)acetate (13)}

It was obtained as yellow solid in 69\% yield following general procedure above using ethyl (Z)-2hydrazineylidene-2-(4-methoxyphenyl)acetate $(111 \mathrm{mg})$ as starting material. The NMR data are consistent with literature values. ${ }^{13}$

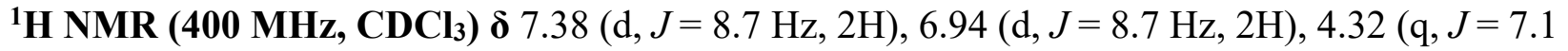
$\mathrm{Hz}, 2 \mathrm{H}), 3.81(\mathrm{~s}, 3 \mathrm{H}), 1.33(\mathrm{t}, J=7.1 \mathrm{~Hz}, 3 \mathrm{H})$.

${ }^{13}$ C NMR (101 MHz, CDCl 3$) \delta$ 165.8, 158.0, 126.0, 117.1, 114.6, 60.9, 55.4, 14.5 (The resonance resulting from the diazo carbon was not observed). 
<smiles>CCOC(=O)C(C#N)c1ccc(Cl)nc1</smiles>

\section{Ethyl 2-(6-chloropyridin-3-yl)-2-diazoacetate (14)}

It was obtained as yellow solid in 97\% yield following general procedure above using ethyl $(E)$ 2-(6-chloropyridin-3-yl)-2-hydrazineylideneacetate (114 mg) as starting material. The NMR data are consistent with literature values. ${ }^{13}$

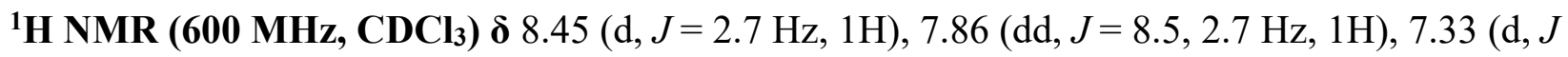
$=8.5 \mathrm{~Hz}, 1 \mathrm{H}), 4.35(\mathrm{q}, J=7.1 \mathrm{~Hz}, 2 \mathrm{H}), 1.35(\mathrm{t}, J=7.1 \mathrm{~Hz}, 3 \mathrm{H})$.

${ }^{13}$ C NMR (151 MHz, $\left.\mathbf{C D C l}_{3}\right) \delta$ 164.3, 148.4, 144.4, 133.8, 124.2, 122.0, 61.6, 14.4 (The resonance resulting from the diazo carbon was not observed).

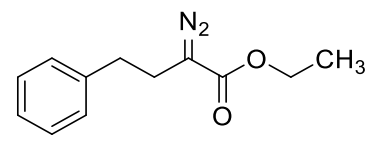

\section{Ethyl 2-diazo-4-phenylbutanoate (15)}

It was obtained as yellow solid in $87 \%$ yield following general procedure above using ethyl $(E)$ 2-hydrazineylidene-4-phenylbutanoate $(110 \mathrm{mg})$ as starting material. The NMR data are consistent with literature values. ${ }^{2}$

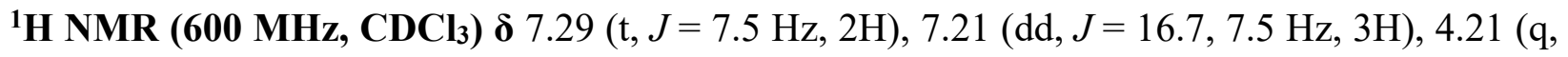
$J=7.1 \mathrm{~Hz}, 2 \mathrm{H}), 2.83(\mathrm{t}, J=7.5 \mathrm{~Hz}, 2 \mathrm{H}), 2.60(\mathrm{t}, J=7.5 \mathrm{~Hz}, 2 \mathrm{H}), 1.26(\mathrm{t}, J=7.1 \mathrm{~Hz}, 3 \mathrm{H})$.

${ }^{13}$ C NMR (151 MHz, $\left.\mathbf{C D C l}_{3}\right) \boldsymbol{\delta}$ 167.5, 140.1, 128.6, 128.5, 126.4, 60.8, 34.0, 25.4, 14.5 (The resonance resulting from the diazo carbon was not observed). 
<smiles>N#CC(=O)c1ccc(Br)cc1</smiles>

\section{1,2-bis(4-bromophenyl)-2-diazoethan-1-one (16)}

It was obtained as yellow solid in $92 \%$ yield following procedure similar to general procedure above using (Z)-1,2-bis(4-bromophenyl)-2-hydrazineylideneethan-1-one (191 mg) as starting material, and the variation are: $2 \%$ pyridine in dichloromethane as solvent, reaction in dark.

mp: $88-90{ }^{\circ} \mathrm{C}$ (decomp.). $\mathbf{R f}=0.46(10 \%$ ethyl acetate/hexane $)$.

${ }^{1}$ H NMR (600 MHz, CDCl $)$ ) $7.57(\mathrm{~d}, J=8.6 \mathrm{~Hz}, 2 \mathrm{H}), 7.53(\mathrm{~d}, J=8.9 \mathrm{~Hz}, 2 \mathrm{H}), 7.47$ (d, $J=8.6$ $\mathrm{Hz}, 2 \mathrm{H}), 7.33$ (d, $J=8.7 \mathrm{~Hz}, 2 \mathrm{H})$.

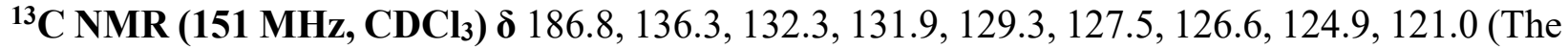
resonance resulting from the diazo carbon was not observed).

IR (neat) 3087, 2071, 1621, 1586, 1488, 1337, 1244, 1070, 1010, 856, $822 \mathrm{~cm}^{-1}$.

HRMS (+p APCI) calcd for $\mathrm{C}_{14} \mathrm{H}_{8} \mathrm{Br}_{2} \mathrm{~N}_{2} \mathrm{ONa}(\mathrm{M}+\mathrm{Na})^{+} 400.8896$ found 400.88621 .<smiles>N#CC1=Nc2ccccc2C1=O</smiles>

\section{3-diazoindolin-2-one (17)}

It was obtained as yellow solid in 99\% yield following general procedure above using 3hydrazonoindolin-2-one $(2: 1 Z: E, 80.6 \mathrm{mg})$ as starting material. The NMR data are consistent with literature values. ${ }^{14}$

${ }^{1}$ H NMR (600 MHz, CD $\mathbf{O}$ OD) $\delta 7.32-7.25(\mathrm{~m}, 1 \mathrm{H}), 7.13(\mathrm{td}, J=7.7,1.2 \mathrm{~Hz}, 1 \mathrm{H}), 7.06(\mathrm{td}, J=$ 7.6, $1.0 \mathrm{~Hz}, 1 \mathrm{H}), 6.97$ (dt, $J=7.8,0.8 \mathrm{~Hz}, 1 \mathrm{H})$.

${ }^{13}$ C NMR (151 MHz, CD 3 OD) $\delta$ 169.4, 132.3, 125.1, 121.7, 118.3, 117.2, 110.1 (The resonance resulting from the diazo carbon was not observed). 


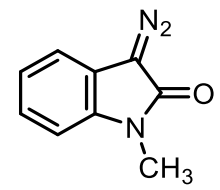

\section{3-diazo-1-methylindolin-2-one (18)}

It was obtained as yellow solid in 98\% yield following general procedure above using 3hydrazono-1-methylindolin-2-one (17:1 Z:E, 87.6 mg) as starting material. The NMR data are consistent with literature values. ${ }^{2}$

${ }^{1}$ H NMR (600 MHz, $\left.\mathbf{C D C l}_{3}\right) \boldsymbol{\delta} 7.22-7.18(\mathrm{~m}, 2 \mathrm{H}), 7.11-7.07(\mathrm{~m}, 1 \mathrm{H}), 6.94-6.90(\mathrm{~m}, 1 \mathrm{H})$, $3.33(\mathrm{~s}, 3 \mathrm{H})$.

${ }^{13}$ C NMR (151 MHz, $\left.\mathbf{C D C l}_{3}\right) \boldsymbol{\delta} 166.8,134.5,125.5,122.1,118.2,116.7,108.6,26.8$ (The resonance resulting from the diazo carbon was not observed). 


\section{React-IR Experiment Set-up and Procedure}

The React-IR instrument was filled with liquid nitrogen and allowed to equilibrate while the reaction flask was being set-up. An oven-dried $100 \mathrm{~mL}$ 3-neck round-bottom flask was fitted with React-IR probe at the center neck (19/25 neck with 24/40 to 19/25 adapter to fit the probe) and the other two necks were fitted with rubber septa (14/20 neck) as shown below.

The flask was cooled to room temperature under vacuum, then backfilled with oxygen ( 3 times and then left the balloon at the left neck) and placed in a water bath (maintain at room temperature) with stir rate set as $800 \mathrm{rpm}$. After background and water vapor spectrum were taken for calibration of the instrument, $\mathrm{Cu}(\mathrm{OAc})_{2}-\mathrm{H}_{2} \mathrm{O}(59.9 \mathrm{mg}, 0.3 \mathrm{mmol}, 20 \mathrm{~mol} \%)$ and silica powder $(300 \mathrm{mg}$, SiliaFlash ${ }^{\circledR}$ P60, 40-63 $\mu \mathrm{m}$ ) were added. Then, the reaction vessel was purged with oxygen (vacuum/oxygen cycle $\times 3$ and the oxygen balloon was left at the left neck) before the addition of $12 \mathrm{~mL}$ of dry and degassed dichloromethane. The data collection was started on the software, and the initial reaction mixture was allowed to stir for 10 minutes. A reference spectrum of the initial reaction mixture was taken, a solution of 2,2,2-trichloroethyl (Z)-2-(4-bromophenyl)-2hydrazineylideneacetate in $3 \mathrm{~mL}$ dry and degassed dichloromethane was added in one portion via syringe from the left neck (noted quickly on the software). The mixture was stirred at room temperature and the increase of $\mathrm{C}=\mathrm{N}_{2}$ stretch frequency $\left(2103 \mathrm{~cm}^{-1}\right)$ was monitored until it reacted the maximum and stay steady for $10 \mathrm{~min}$ (or $4 \mathrm{~h}$ after the addition, whichever came first).

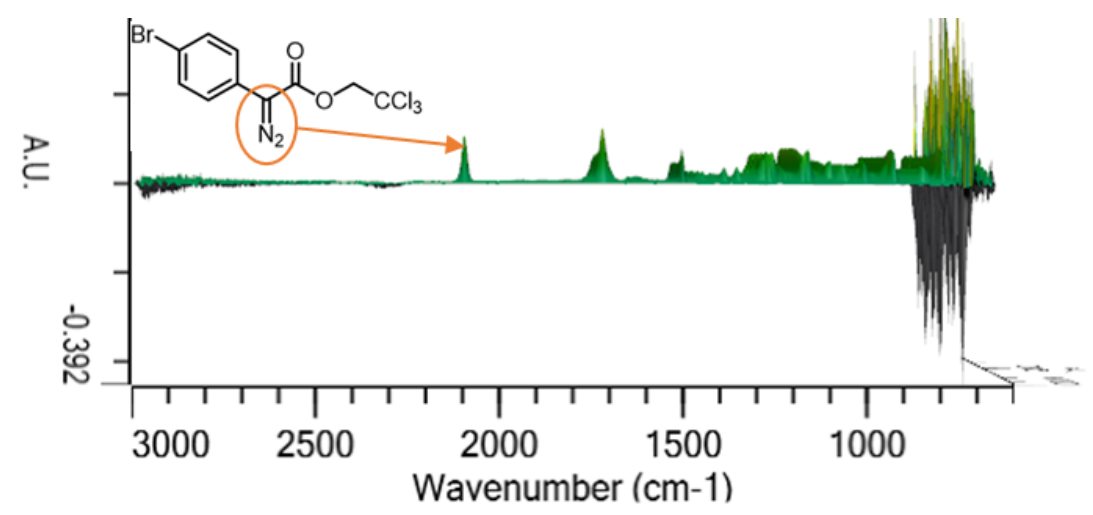

Figure S1. The characteristic peak of diazo compound $2(2103 \mathrm{~cm}-1)$ monitored by ReactIR in the reaction progress. 


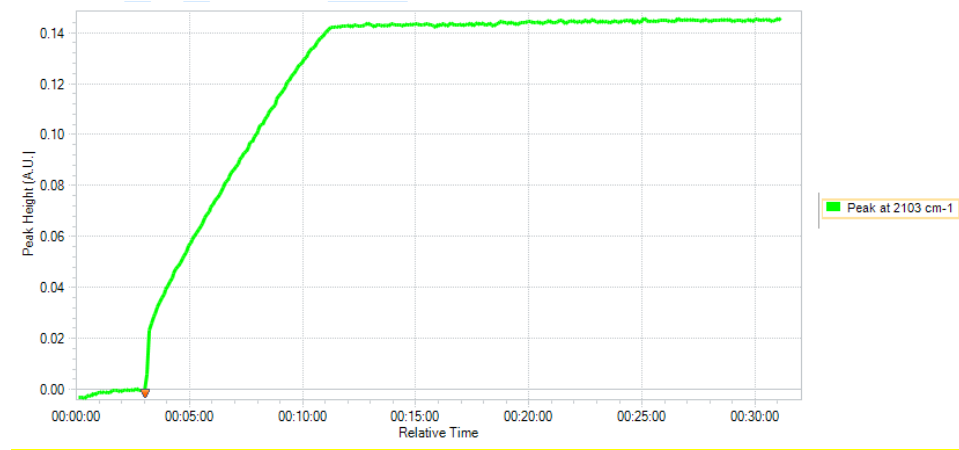

Figure S2. ReactIR Run on Software for A Complete Experiment.

The data was extracted directly from the software as in text format and pasted into Microsoft Excel. The first time point, where it was noted that the hydrazone was injected, was set as "0" (minutes) and all subsequent time points are set relatively after it. To normalize the absorbance, the absorbance of the maximum value in experiments that went completion (with $\mathrm{NEt}_{3}$ and pyridine as additive, averaged) was set as " 1 ", and all subsequent absorbances are divided by the absorbance of that point. In doing so, it is possible to get the relative concentration of diazo and to monitor the time of the diazo generation. 


\section{Crystallization and Reaction of Complex 19}

Crystallization: $\mathrm{Cu}(\mathrm{OAc})_{2} \bullet \mathrm{H}_{2} \mathrm{O}(20 \mathrm{mg})$ was dissolved in $4 \mathrm{~mL}$ of dichloromethane with $0.05 \mathrm{~mL}$ of pyridine. The crystals were obtained after slow evaporation of the solution under room temperature. X-ray crystallography analysis of the single crystal showed that it was the paddlewheel structure (Figure S3) matched with literature. ${ }^{15}$

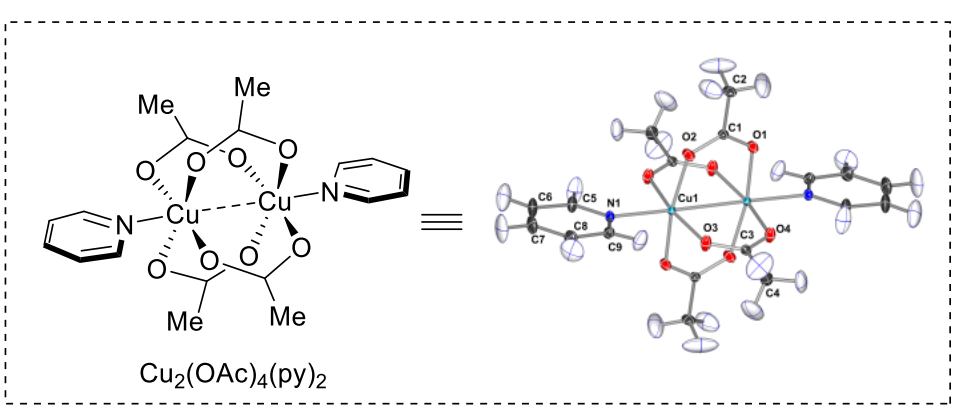

Figure S3. Crystal structure of complex 19

The obtained complex 19 in crystalline form was applied in the same reaction condition as the optimal one for reference substrate (generating 2,2,2-trichloroethyl 2-(4-bromophenyl)-2diazoacetate) without pyridine additive: A $20 \mathrm{~mL}$ scintillation vial equipped with stir bar (bigger size, egg shape) was charged with Complex 19 (14 mg, $0.05 \mathrm{mmol}, 10 \mathrm{~mol} \%$ ), silica powder (100 $\mathrm{mg}$, SiliaFlash $\left.{ }^{\circledR} \mathrm{P} 60,40-63 \mu \mathrm{m}\right)$ and $2 \mathrm{~mL}$ of dichloromethane. The reaction vessel with a 14/20 septum was flushed with $\mathrm{O}_{2}$ and the $\mathrm{O}_{2}$ balloon (double layered) was left on the septum. Another $2.2 \mathrm{~mL}$ of dichloromethane was added, and the initial mixture was stirred vigorously (600 rpm) for $5 \mathrm{~min}$. A solution of corresponding hydrazone $(0.5 \mathrm{mmol}, 1.0$ equiv) in $1 \mathrm{~mL}$ of dichloromethane was added in one portion, and the reaction mixture was stirred for $1 \mathrm{~h}$ at room temperature $\left(23^{\circ} \mathrm{C}\right)$. After allowed time passed, the resulted mixture was filtered through a short pipet of silica $\left(0.9 \mathrm{~cm}\right.$ diameter, $5 \mathrm{~cm}$ height) and concentrated for crude ${ }^{1} \mathrm{H}$ NMR. Further purification was conducted using flash column chromatography (0-3\% diethyl ether in hexane). The desired 2,2,2-trichloroethyl 2-(4-bromophenyl)-2-diazoacetate was obtained as yellow solid in $96 \%$ yield. 
Table S1. Properties of the bond critical points and delocalization of $\mathrm{Cu}-\mathrm{O}, \mathrm{Cu}-\mathrm{N}$ and $\mathrm{Cu}-\mathrm{Cu}$ interactions.

\begin{tabular}{|c|c|c|c|c|c|}
\hline & $\rho_{\text {bcp }}$ & $\nabla^{2} \rho_{b c p}$ & $\varepsilon$ & $\mathbf{H}_{\text {bcp }}$ & $\mathbf{D I}(\mathbf{A} \mid \mathbf{B})$ \\
\hline & \multicolumn{5}{|l|}{$\mathbf{M} \cdots \mathbf{L}$} \\
\hline $\mathrm{Cu}-\mathrm{O}$ & 0.0842 & +0.360 & 0.0100 & -0.023 & 0.422 \\
\hline $\mathrm{Cu}-\mathbf{N}$ & 0.0603 & +0.233 & 0.0482 & -0.011 & 0.343 \\
\hline \multirow[t]{2}{*}{$\mathrm{Cu}-\mathrm{Cu}$} & 0.0320 & +0.058 & 0.0039 & -0.005 & 0.465 \\
\hline & \multicolumn{5}{|l|}{ ligands } \\
\hline C-O & 0.377 & -0.533 & 0.101 & -0.655 & 1.103 \\
\hline $\mathrm{C}-\mathbf{N}$ & 0.341 & -1.08 & 0.112 & -0.510 & 1.294 \\
\hline C-C & 0.317 & -0.911 & $0.17,0.19$ & -0.330 & $1.358,1.391$ \\
\hline C-H & 0.289 & -1.070 & 0.014 & -0.310 & $0.90,0.95$ \\
\hline
\end{tabular}

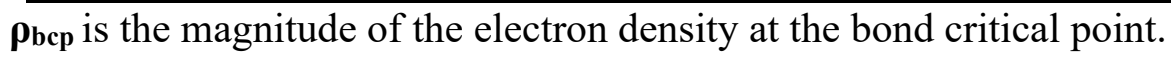

$\nabla^{2} \rho_{\text {bcp }}$ is a measure of the local charge concentration (+ve) or depletion (-ve).

$\boldsymbol{\varepsilon}$ is the ellipticity at the bond critical point ( 0.0 is cylindrical (eg. sigma bond), 0.17 elongated ( $\pi$ bonds).

$\mathbf{H}_{\mathbf{b c p}}$ is the Cremer and Kraka energy density. The Cremer and Kraka energy density H(r) = G(r) $+\mathrm{V}(\mathrm{r})$ is equivalent to $-\mathrm{K}(\mathrm{r})$, i.e., minus the Hamiltonian form of the electron kinetic energy density.

$\operatorname{DI}(\mathbf{A} \mid \mathbf{B})$ is the bond delocalization index, i.e. number of shared pairs and corresponds to the bond order (the number of electrons shared between two atoms).

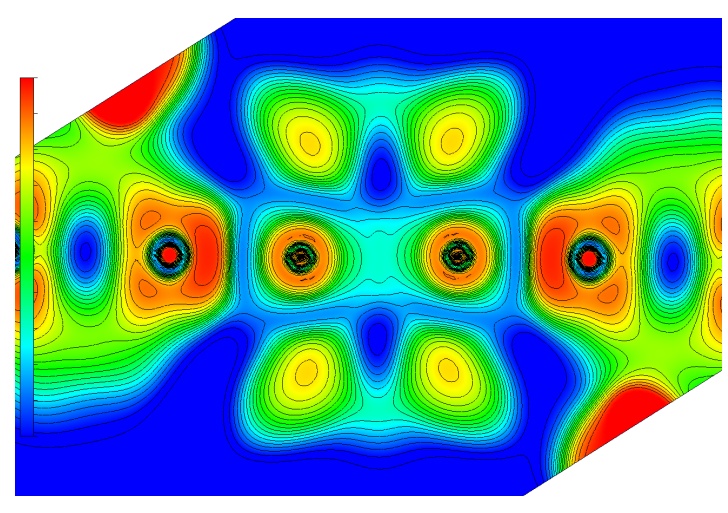

Figure S4. Contour map of the Electron Localization Function (ELF) in a plane containing the $\mathrm{N}-\mathrm{Cu}-\mathrm{Cu}-\mathrm{N}$ axis. Lone pair electrons, and electron sharing between the two $\mathrm{Cu}$ centers are visible. 


\section{Kinetic Measurements}

\section{General Procedure}

Stock solutions were prepared in volumetric flasks with sufficient quantity to enable the same stock solution to be used throughout each series of measurements to ensure consistency. A heavywalled tube with a stir bar was charged with a $0.01 \mathrm{mM}$ stock solution of $\mathrm{Cu}(\mathrm{OAc})_{2} \bullet \mathrm{H}_{2} \mathrm{O}(1 \mathrm{~mL}$, $0.01 \mathrm{mmol}$ ) and silica $(60 \mathrm{mg})$ in $\mathrm{CH}_{2} \mathrm{Cl}_{2}$. The $\mathrm{CH}_{2} \mathrm{Cl}_{2}$ was then removed under reduced pressure (speed-vac $\left.{ }^{\circledR}\right)$. This tube was attached to a pressure transducer, evacuated and refilled with 1 atm $\mathrm{O}_{2}$ three times, and then pressurized to the appropriate pressure. The tube was placed in a heating block maintained at $30{ }^{\circ} \mathrm{C}$. Meanwhile, a stock solution of $75 \mathrm{mM}$ pyridine in $\mathrm{ClCH}_{2} \mathrm{CH}_{2} \mathrm{Cl}$ was prepared and an aliquot $(0.8 \mathrm{~mL}, 0.06 \mathrm{mmol})$ was added to the tube through a thick rubber septum. Magnetic stirring was begun (1200 RMP) and the pressure was monitored until it had equalized. Meanwhile, a stock solution of $500 \mathrm{mM}(Z)-19$ (ethyl (Z)-2-hydrazineylidene-2-phenylacetate) was prepared, after the pressure had equalized in the tube, $0.2 \mathrm{~mL}$ of this stock solution $(0.1 \mathrm{mmol}$ of (Z)-19) was injected into the tube through the septum and the pressure was monitored during the reaction. The data points were plotted and fitted with a linear regression to determine the initial rate of $\mathrm{O}_{2}$ consumption.

\section{Analysis of Pyridine Electronic Effects}

A stock solution of each pyridine derivative was prepared in dichloroethane, and kinetic data were obtained by following the general procedure described above. Initial rate data were obtained via linear regression of the $\mathrm{O}_{2}$ consumption data at less than $30 \%$ conversion of substrate (Figure S5). The natural logarithms of the relative initial rates were then plotted against the $\mathrm{p} K_{\mathrm{a}}$ of the corresponding pyridininum species and analyzed by linear regression (Figure 3 in the manuscript). 

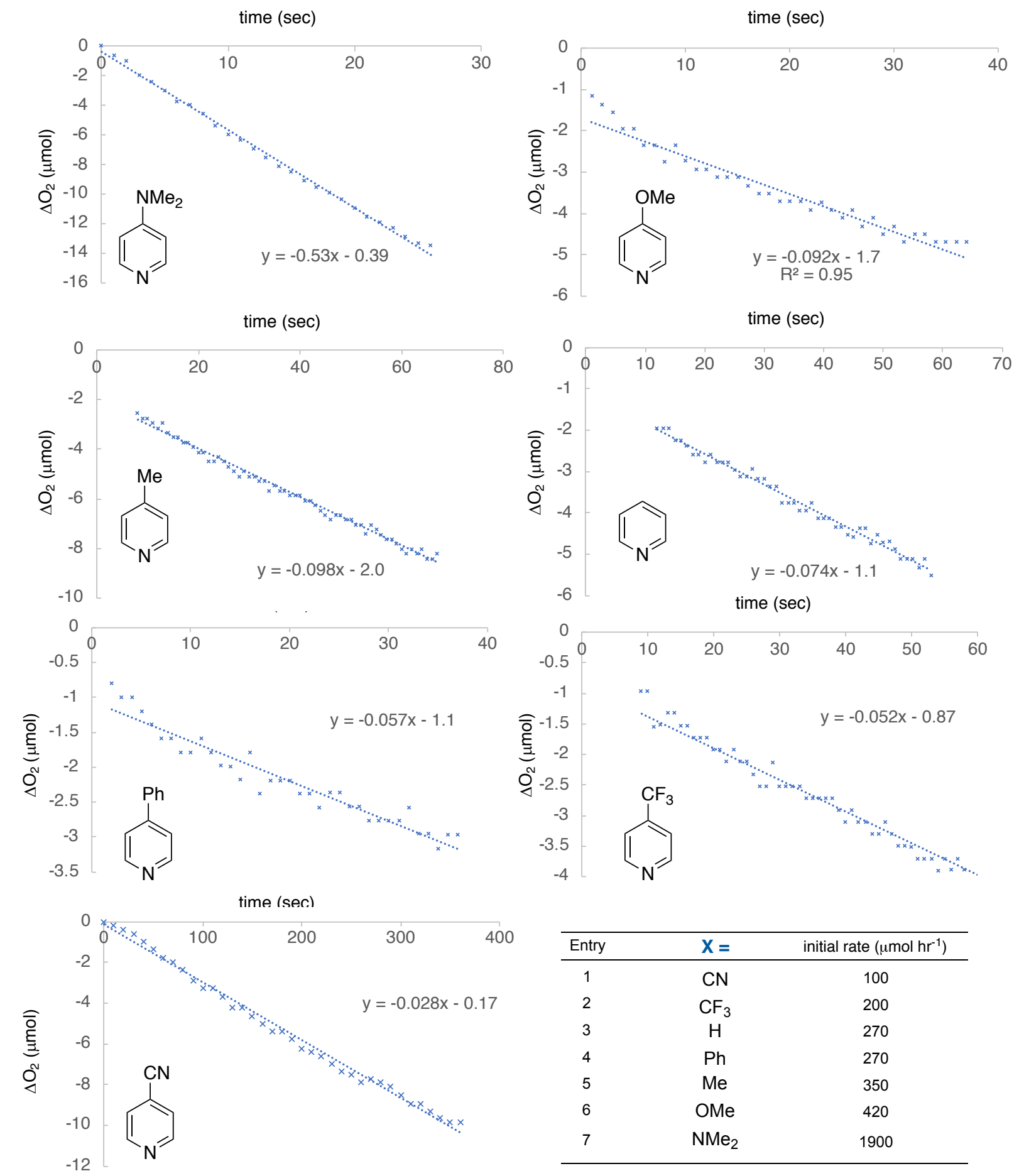

Figure S5. Initial rate data obtained by using gas-uptake kinetics for the $\mathrm{Cu}(\mathrm{OAc})_{2} /$ pyridinecatalyzed aerobic oxidation of hydrazone (Z)-19 with seven different pyridine derivatives. 


\section{Reaction Order Determination}

Kinetic data were acquired according to the general procedure above, with concentrations of individual reagents varied by modifying the amount of stock solution added to the reaction mixture, while maintaining a consistent total volume of dichloroethane $(1 \mathrm{~mL})$. Initial rates for the reagent concentration dependence plots reflect values averaged from of 3 experiments, with the exception of the $\mathrm{PO}_{2}$ data, which reflect an average from 2 experiements. The initial rates were plotted against the concentration of the relevant reagent or $\mathrm{PO}_{2}(\mathrm{~atm})$ and fitted to a linear regression to determine the reaction order in each component (Figure $\mathrm{S} 6$ ).
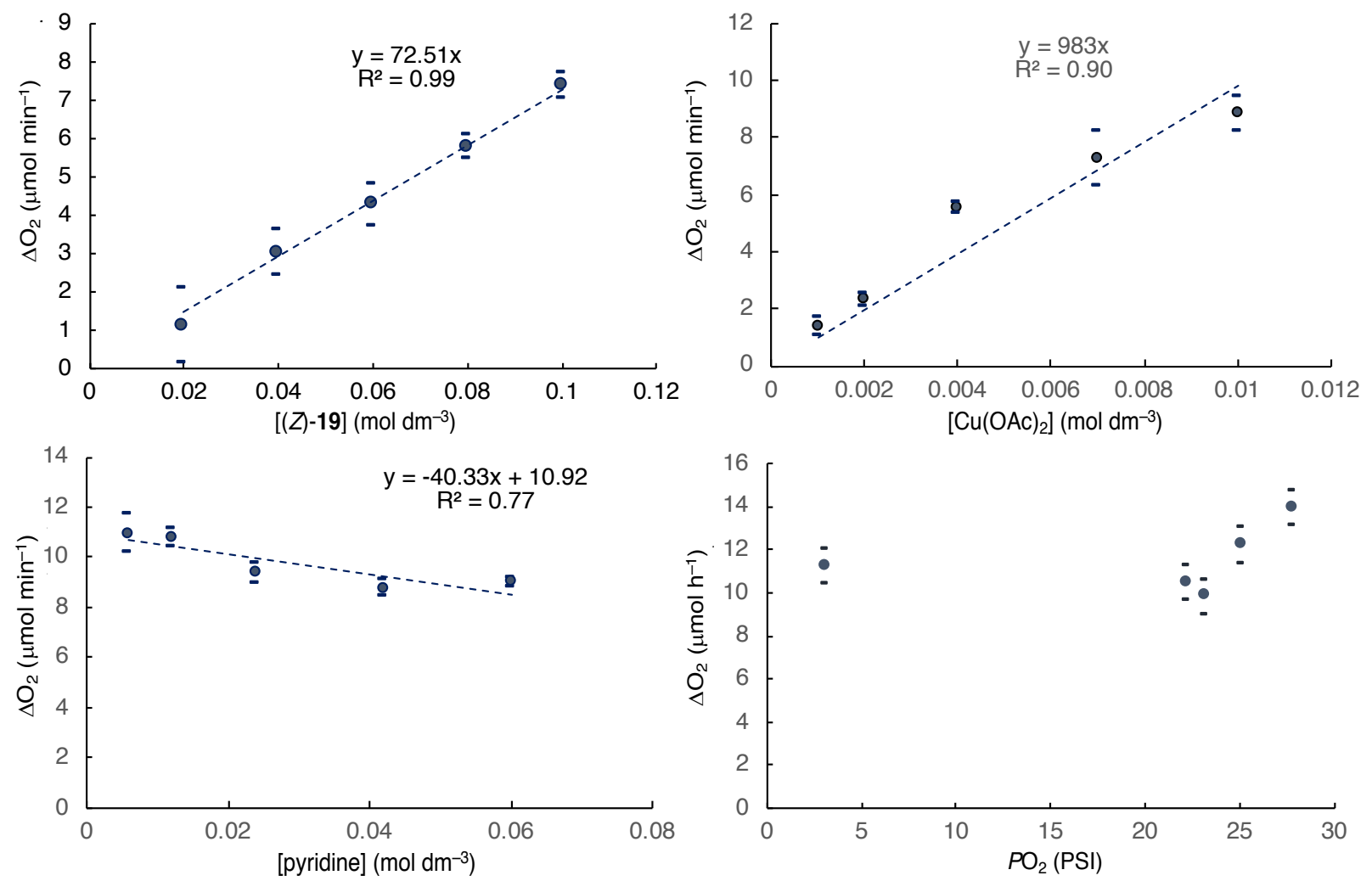

Figure S6. Kinetic plots showing the dependence of the initial rate on the concentration (or pressure) of the different reaction components. Error bars are one standard deviation from the average value from triplicate run. 


\section{Optimization of Diaryl Hydrazone Oxidation}

\section{Optimization Procedure ${ }^{16}$}

To a 96-well optimization block (Analytical Sales and Services) with $1 \mathrm{ml}$ glass vial inserts (Analytical Sales and Services) fitted with PTFE coated stir bars, was dispensed solutions of $\mathrm{Cu}$ (carboxylate) (as a slurry) and pyridine additive in the designated solvent in order to achieve the desired catalyst loadings for a reaction performed on $10 \mu \mathrm{mol}$ scale - additional solvent was added to bring the total volume in each well to $50 \mu 1$ at this stage. The blocks were then aged for 1 minute. Then, $50 \mu \mathrm{l}$ of a solution of benzophenone hydrazone $(10 \mu \mathrm{mol}, 0.2 \mathrm{M})$ was dispensed to the vials. The plate was then sealed with a screw driver and agitated utilizing a tumble stirrer (V\&P Scientific) for 2 hours - the block was cooled by a fan placed adjacent. The block was then diluted with a solution of 1,3,5-trimethoxybenzene in 9:1 acetonitrile/AcOH ( $2 \mu \mathrm{mol}, 0.01 \mathrm{M}, 200$ $\mu \mathrm{l})$, sealed and agitated for $1 \mathrm{~h}$ to convert the in-situ generated diazo compound to benzhydryl acetate. ${ }^{4}$ The block was then opened and diluted with a 3:1 solution of MeCN/DMSO $(200 \mu 1)$ and sampled $(5 \mu \mathrm{l})$ into an HPLC collection block pre-filled with acetonitrile $(200 \mu \mathrm{l})$. The HPLC collection block was then analyzed utilizing UPLC-MS analysis and yields were determined with respect to 1,3,5-trimethoxybenzene utilizing calibration curves.

Changes were made to this procedure in order to minimize the number of operations for each variable that was evaluated. Select example showing logical progression of our optimization are shown in Figure S2. The optimized conditions were found to scale up adequately to $0.2 \mathrm{mmol}$ for compound isolation. 
Table S2. Optimization of Diaryl Hydrazone Oxidation

\begin{tabular}{|c|c|c|c|c|c|}
\hline \multirow[b]{2}{*}{ Entry } & $\begin{array}{r}{[\mathrm{Cu}](10 \mathrm{mo}} \\
\text { additive } \\
\text { air }(1 \mathrm{~atm}), \text { sol } \\
23^{\circ} \mathrm{C}, 2 \mathrm{~h}\end{array}$ & & 24 & $\frac{\mathrm{AcOH}}{\mathrm{MeCN}}$ & $\left.\right|_{25} ^{O A C}$ \\
\hline & [Cu] & Solvent & additive & & yield $(\mathbf{X X}), \%$ \\
\hline 1 & $\mathrm{Cu}(\mathrm{OAc})_{2} \cdot \mathrm{H}_{2} \mathrm{O}$ & $\mathrm{CH}_{2} \mathrm{Cl}_{2}$ & pyridine & 5 equiv), silica & $<5$ \\
\hline 2 & $\mathrm{Cu}(\mathrm{OAc})_{2} \cdot \mathrm{H}_{2} \mathrm{O}$ & DCE & pyridine & 5 equiv), silica & 7 \\
\hline 3 & $\mathrm{Cu}(\mathrm{OAc})_{2} \cdot \mathrm{H}_{2} \mathrm{O}$ & DCE & DMAP $(0$ & equiv), silica & 17 \\
\hline 4 & $\mathrm{Cu}(\mathrm{OAc})_{2} \cdot \mathrm{H}_{2} \mathrm{O}$ & DCE & $\operatorname{DMAP}(0$ & equiv) & 34 \\
\hline 5 & $\mathrm{Cu}(\mathrm{OAc})_{2} \cdot \mathrm{H}_{2} \mathrm{O}$ & DCE & P1 $(0.5 \mathrm{e}$ & & 38 \\
\hline 6 & $\mathrm{Cu}(\mathrm{OAc})_{2} \cdot \mathrm{H}_{2} \mathrm{O}$ & DCE & P2 $(0.5 \mathrm{e}$ & & 34 \\
\hline 7 & $\mathrm{Cu}(\mathrm{OAc})_{2} \cdot \mathrm{H}_{2} \mathrm{O}$ & DCE & P3 $(0.5 \mathrm{e}$ & & 24 \\
\hline 8 & $\mathrm{Cu}(\mathrm{OAc})_{2} \cdot \mathrm{H}_{2} \mathrm{O}$ & DCE & P4 $(0.5 \mathrm{e}$ & & 59 \\
\hline 9 & $\mathrm{Cu}(\mathrm{OAc})_{2} \cdot \mathrm{H}_{2} \mathrm{O}$ & $\mathrm{PC}$ & P4 (0.5 e & & 66 \\
\hline 10 & $5 \mathrm{~mol} \% \mathrm{Cu}(\mathrm{OAc})_{2} \cdot \mathrm{H}_{2} \mathrm{O}$ & PC & P4 (0.25 & juiv) & 84 \\
\hline 11 & $5 \mathrm{~mol} \% \mathrm{Cu}\left(\mathrm{CF}_{3} \mathrm{CO}_{2}\right)_{2} \cdot \mathrm{H}_{2} \mathrm{O}$ & $\mathrm{PC}$ & P4 $(0.5 \mathrm{e}$ & & 79 \\
\hline 12 & $5 \mathrm{~mol} \% \mathrm{Cu}\left(\mathrm{CF}_{3} \mathrm{CO}_{2}\right)_{2} \cdot \mathrm{H}_{2} \mathrm{O}$ & DCE & P4 (0.25 & uiv) & 87 \\
\hline 13 & $5 \mathrm{~mol} \% \mathrm{Cu}(\mathrm{OAc})_{2} \cdot \mathrm{H}_{2} \mathrm{O}$ & PC & DMAP $(0$ & 5 equiv) & 64 \\
\hline 14 & $5 \mathrm{~mol} \% \mathrm{Cu}(\mathrm{OAc})_{2} \cdot \mathrm{H}_{2} \mathrm{O}$ & PC & P1 $(0.25$ & juiv) & 73 \\
\hline 15 & $5 \mathrm{~mol} \% \mathrm{Cu}(\mathrm{OAc})_{2} \cdot \mathrm{H}_{2} \mathrm{O}$ & PC & P2 $(0.25$ & |uiv) & 75 \\
\hline 16 & $5 \mathrm{~mol} \% \mathrm{Cu}(\mathrm{OAc})_{2} \cdot \mathrm{H}_{2} \mathrm{O}$ & PC & P3 $(0.25$ & fuiv) & 68 \\
\hline
\end{tabular}

aReaction conditions: a solution of hydrazone $(0.01 \mathrm{mmol})$ in $0.05 \mathrm{~mL}$ of solvent was added in 1 to a vial with [Cu] and additive in $0.05 \mathrm{~mL}$ of solvent under air at $23^{\circ} \mathrm{C}$. The mixture was stirred vigorously for $2 \mathrm{hrs}$ then cooled to $0^{\circ} \mathrm{C}$ and quenched with $\mathrm{AcOH}$ ( $20 \mathrm{uL}$ in $200 \mathrm{uL} \mathrm{MeCN})$. A stock solution of IS (1,3,5-triemthoxybenzene was added and assay yield was determined by calibrated UPLC analysis. DCE $=1,2-$ dichloroethane, $\mathrm{PC}=$ propylene carbonate, TFA = trifluoroacetate

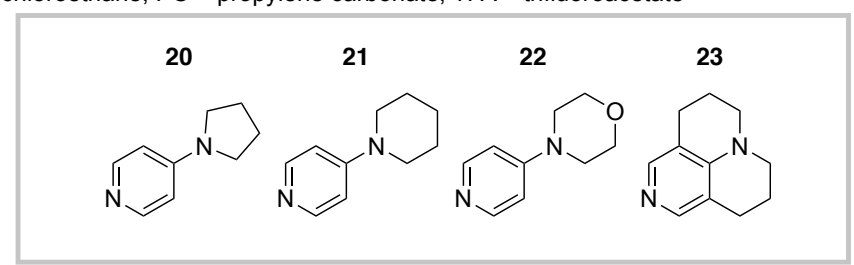




\section{Diaryl Hydrazone Oxidation and Product Characterization}

\section{General Procedure for Diaryl Hydrazone Oxidation}

To a $8 \mathrm{~mL}$ vial fitted with a cross shaped stir bar, was added $0.20 \mathrm{mmol}$ of diaryl hydrazone substrate. A solution of $\mathrm{Cu}(\mathrm{TFA})_{2} \bullet \mathrm{H}_{2} \mathrm{O}(5 \mathrm{~mol} \%, 3.1 \mathrm{mg}, 0.01 \mathrm{mmol})$ and 9azajulolidine (20 mol\%, $7.0 \mathrm{mg}, 0.04 \mathrm{mmol})$ in 1,2-Dichloroethane $(2.0 \mathrm{~mL})$ was added via an air displacement pipette and the vial was capped with pierceable septa fitted cap. A 16-gauge needle was inserted through the septa to facilitate movement of air and the reaction was stirred vigorously at $0{ }^{\circ} \mathrm{C}$ for $16 \mathrm{~h}$. The reaction was stopped, concentrated and the crude material was purified using an alumina column under gradient of 0 to $5 \%$ diethyl ether in hexanes to obtain purified diaryl diazo compounds.<smiles>N#Cc1ccccc1</smiles>

\section{(diazomethylene)dibenzene (24)}

Compound 24 was obtained as a purple solid in $58 \%$ yield $(22 \mathrm{mg})$ following the general procedure above using (diphenylmethylene)hydrazine $(0.20 \mathrm{mmol})$ as starting material. Spectroscopic data matched that previously reported. ${ }^{3}$

${ }^{1} \mathbf{H}$ NMR (500 MHz, $\mathbf{C D C l}_{3}$ ) $\boldsymbol{\delta} 7.42-7.38$ (m, 2H), $7.33-7.30$ (m, 2H), 7.20 (ddt, $J=8.5,7.3$, $1.2 \mathrm{~Hz}, 1 \mathrm{H})$.

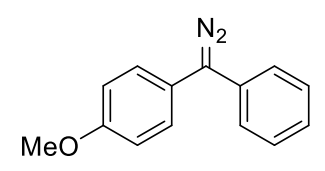

\section{1-(diazo(phenyl)methyl)-4-methoxybenzene (26)}

Compound 26 was obtained as a purple solid in $62 \%$ yield $(28 \mathrm{mg})$ following the general procedure above using ((4-methoxyphenyl)(phenyl)methylene)hydrazine $(0.20 \mathrm{mmol})$ as starting material. Spectroscopic data matched that previously reported. ${ }^{3}$

${ }^{1} \mathbf{H}$ NMR (500 MHz, $\left.\mathbf{C D C l}_{3}\right) \boldsymbol{\delta} 7.38-7.33(\mathrm{~m}, 2 \mathrm{H}), 7.28-7.26(\mathrm{~m}, 2 \mathrm{H}), 7.22-7.19(\mathrm{~m}, 2 \mathrm{H})$, $7.15-7.10(\mathrm{~m}, 1 \mathrm{H}), 6.99-6.95(\mathrm{~m}, 2 \mathrm{H}), 3.84(\mathrm{~s}, 3 \mathrm{H})$. 
<smiles>N#Cc1ccccc1C(=N)c1ccc([N+](=O)[O-])cc1</smiles>

\section{1-(diazo(phenyl)methyl)-4-nitrobenzene (27)}

Compound 27 was obtained as an orange solid in 90\% yield (43 mg) following the general procedure above using ((4-nitrophenyl)(phenyl)methylene)hydrazine $(0.20 \mathrm{mmol})$ as starting material. Spectroscopic data matched that previously reported. ${ }^{3}$

${ }^{1} \mathbf{H}$ NMR (600 MHz, $\left.\mathbf{C D C l}_{3}\right) \boldsymbol{\delta} 7.80-7.77(\mathrm{~m}, 2 \mathrm{H}), 7.05(\mathrm{dd}, J=8.3,7.1 \mathrm{~Hz}, 2 \mathrm{H}), 6.97-6.93$ (m, 1H), $6.89(\mathrm{dd}, J=8.4,1.2 \mathrm{~Hz}, 2 \mathrm{H}), 6.55-6.51(\mathrm{~m}, 2 \mathrm{H})$.<smiles>N#Cc1ccccc1C(=N)c1ccc([N+](=O)[O-])cc1Cl</smiles>

\section{2-chloro-1-(diazo(phenyl)methyl)-4-nitrobenzene (28)}

Compound 28 was obtained as a red/orange solid in $86 \%$ yield $(47 \mathrm{mg})$ following the general procedure above using ((2-chloro-4-nitrophenyl)(phenyl)methylene)hydrazine $(0.20 \mathrm{mmol})$ as starting material. Spectroscopic data matched that previously reported. ${ }^{3}$

${ }^{1}$ H NMR (600 MHz, CDCl $)$ א $8.35(\mathrm{~d}, J=2.4 \mathrm{~Hz}, 1 \mathrm{H}), 8.10(\mathrm{dd}, J=8.7,2.4 \mathrm{~Hz}, 1 \mathrm{H}), 7.53$ (d, $J=8.8 \mathrm{~Hz}, 1 \mathrm{H}), 7.40(\mathrm{dd}, J=8.4,7.5 \mathrm{~Hz}, 2 \mathrm{H}), 7.25-7.20(\mathrm{~m}, 1 \mathrm{H}), 7.16-7.13(\mathrm{~m}, 2 \mathrm{H})$.

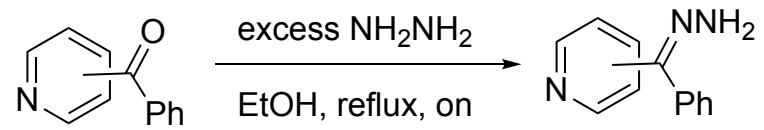

Benzoyl pyridine hydrazone derivatives were prepared via a modified version of a previously reported method. ${ }^{3}$

\section{General Procedure for Benzoyl Pyridine Hydrazone Synthesis}

To a $100 \mathrm{~mL}$ round bottom flask fitted with a magnetic stir bar was added 2-benzoyl-pyridine (1.83 $\mathrm{g}, 10 \mathrm{mmol})$ and ethanol $(30 \mathrm{~mL})$. Hydrazine monohydrate was added (1.5 mL, $30 \mathrm{mmol}, 3$ equiv) dropwise and then the reaction was heated to reflux overnight. Upon cooling to room temperature, the reaction was quenched by addition of sat. $\mathrm{NH}_{4} \mathrm{Cl}(50 \mathrm{~mL})$ and $\mathrm{H}_{2} \mathrm{O}(50 \mathrm{~mL})$. The crude mixture was extracted with EtOAc $(3 \times 50 \mathrm{~mL})$, and the combined organic phase were washed with brine $(100 \mathrm{~mL})$, dried over $\mathrm{MgSO}_{4}$ and concentrated to dryness. The crude residue was recrystallized from a 3:1 mixture of EtOAc/heptanes. 


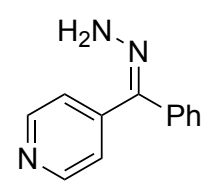

4-(hydrazineylidene(phenyl)methyl)pyridine (29')

4-(hydrazineylidene(phenyl)methyl)pyridine was obtained as an off-white solid in 69\% yield (1.351 g, 97:3 mixture of E/Z isomers) following the procedure above using 4-benzoyl pyridine $(1.83 \mathrm{~g}, 10 \mathrm{mmol})$ as the starting material.

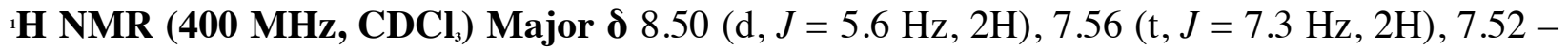
$7.46(\mathrm{~m}, 1 \mathrm{H}), 7.35-7.30(\mathrm{~m}, 2 \mathrm{H}), 7.27(\mathrm{dt}, J=6.4,1.5 \mathrm{~Hz}, 2 \mathrm{H}), 5.75(\mathrm{~s}, 2 \mathrm{H})$.

${ }^{13}$ C NMR (101 MHz, CDCl Major $_{3}$ d 149.81, 145.70, 145.56, 131.50, 129.83, 129.52, 128.90, 120.44 .

IR (neat): 3345, 3148, 2989, 2870, 1636,1573, 1491, 1412, 1339, 1217, 1143, 1063, 829, 772, $770,667 \mathrm{~cm}^{-1}$.

HRMS (ESI-MS) calcd for $\mathrm{C}_{12} \mathrm{H}_{12} \mathrm{~N}_{3}[\mathrm{M}+\mathrm{H}] 198.1026$ - found - 198.1025.

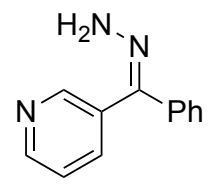

\section{3-(hydrazineylidene(phenyl)methyl)pyridine (30')}

3-(hydrazineylidene(phenyl)methyl)pyridine was obtained as an pale-yellow solid in $64 \%$ yield (1.265 g, 17:3 mixture of $\mathrm{E} / \mathrm{Z}$ isomers) following the procedure above using 3-benzoyl pyridine $(1.83 \mathrm{~g}, 10 \mathrm{mmol})$ as the starting material.

${ }^{1}$ H NMR (400 MHz, CDCl $)$ Major $\delta 8.72(\mathrm{dd}, J=4.9,1.7 \mathrm{~Hz}, 1 \mathrm{H}), 8.57(\mathrm{~d}, J=2.1 \mathrm{~Hz}, 1 \mathrm{H})$, $7.68(\mathrm{dt}, J=7.8,2.0 \mathrm{~Hz}, 1 \mathrm{H}), 7.50-7.45(\mathrm{~m}, 1 \mathrm{H}), 7.45-7.37(\mathrm{~m}, 2 \mathrm{H}), 7.30(\mathrm{dd}, J=5.2,2.0 \mathrm{~Hz}$, $3 \mathrm{H}), 5.50(\mathrm{~s}, 2 \mathrm{H})$.

${ }^{13}$ C NMR (101 MHz, CDCl $)$ Mixture $\delta$ 150.28 (M), $149.88(\mathrm{M}), 148.81$ (m), 148.03 (m), 145.93 (m), 145.53 (M), 137.93 (M), 137.03 (M), 134.17 (m), 133.30 (m), 131.76 (m), 129.69 (m), 129.36 (m), 128.96 (M), 128.75 (m), 128.45 (M), 128.35 (M), 126.28 (M), $124.21(\mathrm{M}), 123.05$ (m). (M Major, $\mathrm{m}-$ minor).

IR (neat): 3341, 3287, 3164, 3010, 1578, 1491, 1475, 1411, 1324, 1284, 1188, 1070, 1042, 966, $813,764,705,692 \mathrm{~cm}^{-1}$.

HRMS (ESI-MS) calcd for $\mathrm{C}_{2}{ }_{2} \mathrm{H}_{12} \mathrm{~N}_{3}[\mathrm{M}+\mathrm{H}] 198.1026$ - found - 198.1024. 
<smiles>N#CC(c1ccccc1)c1ccncc1</smiles>

\section{4-(diazo(phenyl)methyl)pyridine (29)}

Compound 26 was obtained as brick-red oil in 44\% yield (17 mg) following the general procedure above using 4-(hydrazineylidene(phenyl)methyl)pyridine (38.2 mg) as starting material.

$22 \mathrm{mg}$ of crude product was isolated after column chromatography, this material was $77 \%$ pure by proton NMR contaminated with an inseparable $23 \%$ of a ketone byproduct.

${ }^{1}$ H NMR (400 MHz, Acetone-d $)$ ) 8.48 (d, $\left.J=5.8 \mathrm{~Hz}, 2 \mathrm{H}\right), 7.52$ (t, $\left.J=7.7 \mathrm{~Hz}, 2 \mathrm{H}\right), 7.49-7.43$ (m, 2H), $7.36(\mathrm{td}, J=7.1,3.4 \mathrm{~Hz}, 1 \mathrm{H}), 7.16(\mathrm{~d}, J=6.4 \mathrm{~Hz}, 2 \mathrm{H})$.

${ }^{13}$ C NMR (101 MHz, Acetone-d d) $\delta$ 150.02, 139.39, 133.42, 129.54, 127.28, 126.82, 117.38.

IR (neat): 3040, 2910, 2046, 1586, 1496, 1407, 1279, 990, 943, 814, 757, $699 \mathrm{~cm}^{-1}$.

HRMS (ESI-MS) $\mathrm{C}_{12} \mathrm{H}_{10} \mathrm{~N}_{3}\left[\mathrm{M}-\mathrm{N}_{2}+\mathrm{H}-168.0808\right.$ found -168.0809 .<smiles>N#Cc1ccccc1</smiles>

\section{3-(diazo(phenyl)methyl)pyridine (30)}

Compound 26 was obtained as dark-pink oil in 79\% yield $(30 \mathrm{mg})$ following the general procedure above using 3-(hydrazineylidene(phenyl)methyl)pyridine (38.2 mg) as starting material.

${ }^{1}$ H NMR (400 MHz, Acetone-d $)$ $\delta 8.43(\mathrm{~d}, J=2.7 \mathrm{~Hz}, 1 \mathrm{H}), 8.28(\mathrm{~d}, J=3.2 \mathrm{~Hz}, 1 \mathrm{H}), 7.55$ (dt, $J$ $=8.2,2.0 \mathrm{~Hz}, 1 \mathrm{H}), 7.34(\mathrm{t}, J=7.8 \mathrm{~Hz}, 2 \mathrm{H}), 7.29(\mathrm{dd}, J=8.1,4.7 \mathrm{~Hz}, 1 \mathrm{H}), 7.20(\mathrm{~d}, J=8.0 \mathrm{~Hz}, 2 \mathrm{H})$, $7.13(\mathrm{t}, J=7.4 \mathrm{~Hz}, 1 \mathrm{H})$.

${ }^{13}$ C NMR (101 MHz, Acetone-d6) $\delta$ 146.78, 146.23, 131.82, 129.46, 128.40, 126.17, 126.11, 124.96, 123.84. (The resonance resulting from the diazo carbon was not observed).

IR (neat): 3034, 2925, 2036, 1597, 1578, 1494, 1416, 1291, 1268, 1020, 931, 800, 752, 708, 694, $660 \mathrm{~cm}^{-1}$.

HRMS (ESI-MS) calcd for $\mathrm{C}_{12} \mathrm{H}_{10} \mathrm{~N}_{3}[\mathrm{M}+\mathrm{H}]-196.0869$ found - 196.0870. calcd for $\mathrm{C}_{12} \mathrm{H}_{10} \mathrm{~N}$ [M$\left.\mathrm{N}_{2}+\mathrm{H}\right]-168.0808$ found -168.0809 


\section{Tandem Cu-Catalyzed Hydrazone Oxidation and Rh-Catalyzed Carbene}

\section{Transfer}

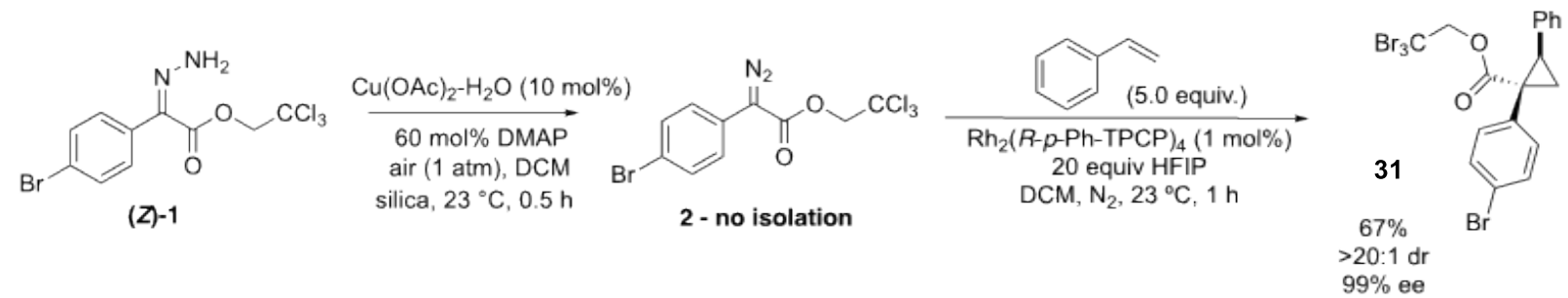

Scheme S2. Tandem Sequence for Cyclopropane Synthesis Donor Acceptor Hydrazone

\section{Procedure}

A $20 \mathrm{~mL}$ scintillation vial was charged with $\mathrm{Cu}(\mathrm{OAc})_{2}-\mathrm{H}_{2} \mathrm{O}(4.0 \mathrm{mg}, 0.020 \mathrm{mmol}, 10 \mathrm{~mol} \%)$, silica

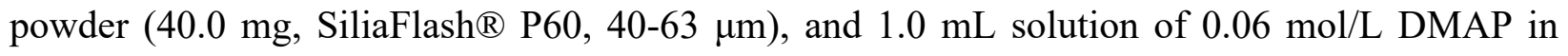
$\mathrm{CH}_{2} \mathrm{Cl}_{2}$ The initial mixture was stirred vigorously with a stir bar (600 rpm) under air for $5 \mathrm{~min}$ before hydrazone was added. In a $4 \mathrm{~mL}$ scintillation vial, 2,2,2-trichloroethyl (Z)-2-(4bromophenyl)-2-hydrazineylideneacetate (Z)-1 (74.9 mg, $0.2 \mathrm{mmol}, 1.0$ equiv) was dissolved in $1.0 \mathrm{~mL}$ of the $0.06 \mathrm{~mol} / \mathrm{L}$ DMAP in $\mathrm{CH}_{2} \mathrm{Cl}_{2}$ solution. The hydrazone/DMAP $\mathrm{CH}_{2} \mathrm{Cl}_{2}$ solution was then transferred by syringe in one portion to the initial mixture of $\mathrm{Cu}(\mathrm{OAc})_{2}-\mathrm{H}_{2} \mathrm{O} /$ silica/DMAP $\mathrm{CH}_{2} \mathrm{Cl}_{2}$ solution. The reaction was stirred for $0.5 \mathrm{~h}$ before next step.

A $20 \mathrm{~mL}$ scintillation vial equipped with a stir bar was flame dried under vacuum. After cooling down, the vail was charged with $\mathrm{Rh}_{2}(R-p-\mathrm{Ph}-\mathrm{TPCP})_{4}(3.5 \mathrm{mg}, 1.0 \mathrm{~mol} \%, 0.002 \mathrm{mmol})$, then flushed with nitrogen for 3 times and the nitrogen balloon was left on the septum. Then HFIP (672.2 mg, $0.42 \mathrm{~mL}, 20$ equiv, $4.0 \mathrm{mmol}$ ), styrene (104.2 mg, $115 \mu \mathrm{L}, 5.0$ equiv, $1.0 \mathrm{mmol}$ ) and $2.0 \mathrm{~mL}$ sparged $\mathrm{CH}_{2} \mathrm{Cl}_{2}$ (sparged with nitrogen for $2 \mathrm{~h}$ before use) were added sequentially via syringe, the mixture was stirred at $600 \mathrm{rpm}$ for $10 \mathrm{~min}$ before crude diazo compound $\mathbf{2}$ injection. The crude diazo compound mixture from copper-catalyzed oxidation $(\sim 1.5 \mathrm{~mL})$ was added by syringe to the styrene $/ \mathrm{Rh}_{2}(R-p \text {-Ph-TPCP })_{4} / \mathrm{HFIP}$ solution in one portion. The reaction was then stirred $1 \mathrm{~h}$ under nitrogen at $23{ }^{\circ} \mathrm{C}$. After completion the solution was concentrated under rotovap and purified by flash column chromatography ( $0 \%$, then $5 \%-15 \% \mathrm{Et}_{2} \mathrm{O}$ in Hexanes). The product was obtained as a single diastereomer as a white solid $(60.1 \mathrm{mg}, 67 \%$ yield, $99 \%$ ee). 
Spectroscopic data matched that previously found in the literature. ${ }^{18}$

${ }^{1}$ H NMR (400 MHz, CDCl $\left.\mathbf{l}_{3}\right) \boldsymbol{\delta} 7.27$ - $7.26(\mathrm{~m}, 2 \mathrm{H}), 7.15$ - 7.04 (m, 3H), 6.98 - 6.89 (m, 2H), $6.80(\mathrm{dd}, J=6.7,2.9 \mathrm{~Hz}, 2 \mathrm{H}), 4.83(\mathrm{~d}, J=11.9,1.1 \mathrm{~Hz}, 1 \mathrm{H}), 4.64(\mathrm{~d}, J=11.9,1.1 \mathrm{~Hz}, 1 \mathrm{H}), 3.22$ $(\mathrm{dd}, J=9.5,7.5 \mathrm{~Hz}, 1 \mathrm{H}), 2.28(\mathrm{dd}, J=9.4,5.2 \mathrm{~Hz}, 1 \mathrm{H}), 1.97(\mathrm{dd}, J=7.5,5.2 \mathrm{~Hz}, 1 \mathrm{H})$.

\section{HPLC Chromatograms}

(AD-H, $30 \mathrm{~min}, 1 \mathrm{~mL} / \mathrm{min}, 1 \% \mathrm{iPrOH}$ in Hexane, UV $230 \mathrm{~nm}$ ) tR: $7.04 \mathrm{~min}, 8.23 \mathrm{~min}$.
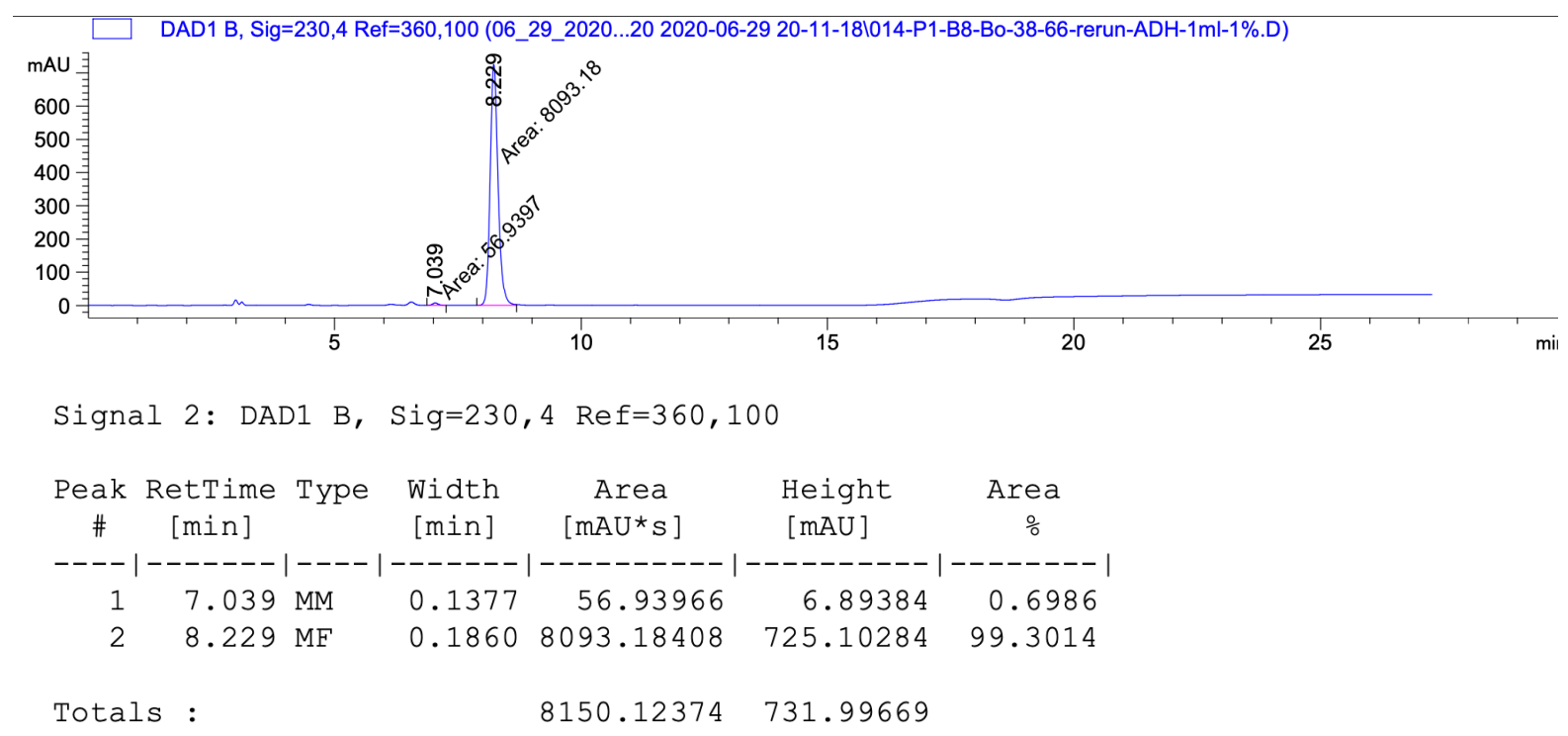

Racemic Trace

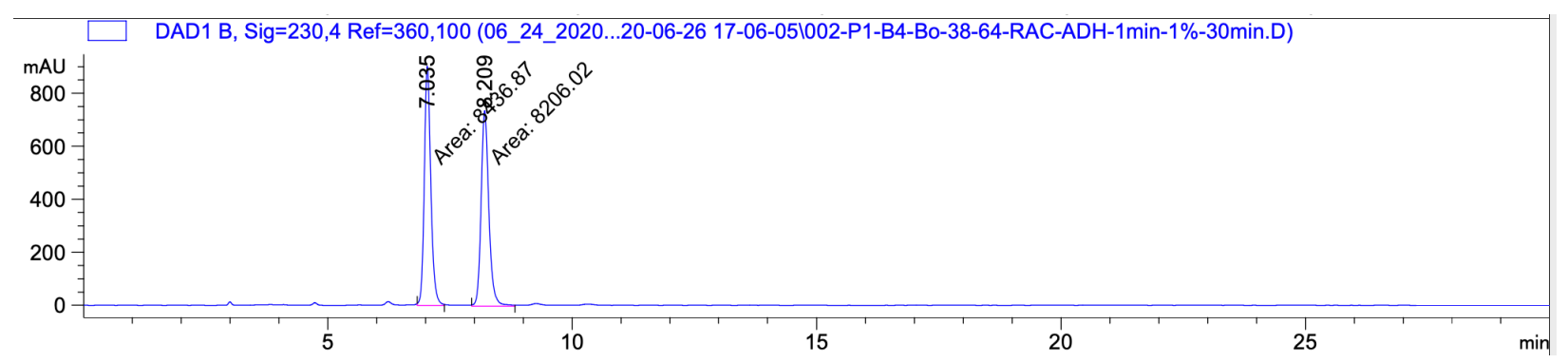

Signal 2: DAD1 B, Sig=230,4 Ref=360,100

\begin{tabular}{|c|c|c|c|c|c|c|}
\hline $\begin{array}{c}\text { Peak } \\
\#\end{array}$ & $\begin{array}{c}\text { RetTime } \\
\text { [min] }\end{array}$ & Type & $\begin{array}{l}\text { Width } \\
\text { [min] }\end{array}$ & $\begin{array}{c}\text { Area } \\
{\left[\mathrm{mAU}^{\star} \mathrm{s}\right]}\end{array}$ & $\begin{array}{l}\text { Height } \\
\text { [mAU] }\end{array}$ & $\begin{array}{c}\text { Area } \\
\frac{\circ}{0}\end{array}$ \\
\hline 1 & 7.035 & MM & 0.1556 & 8436.87012 & 903.51404 & 50.6935 \\
\hline 2 & 8.209 & MM & 0.1852 & 8206.02148 & 738.51477 & 49.3065 \\
\hline Total & : & & & $1.66429 \mathrm{e} 4$ & 1642.02881 & \\
\hline
\end{tabular}




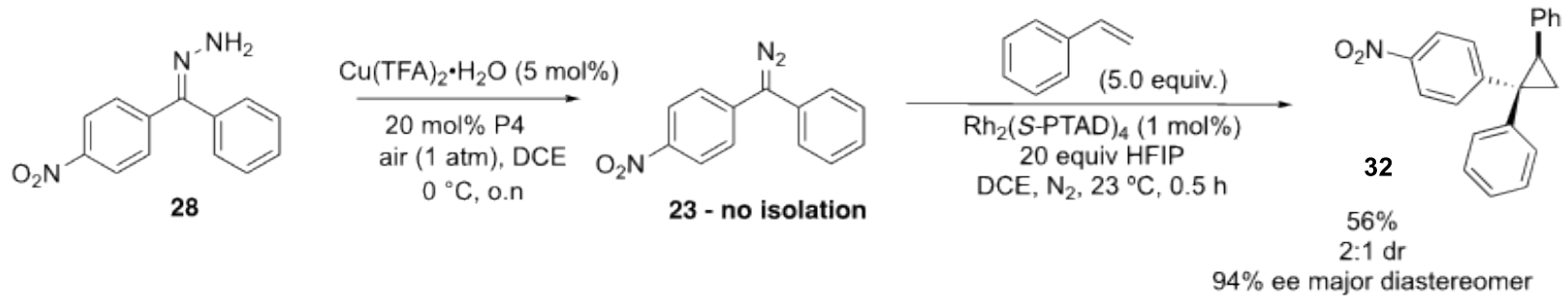

Scheme S3. Tandem Sequence for Cyclopropane Synthesis with Diaryl Hydrazone

A $20 \mathrm{~mL}$ scintillation vial was charged with $\mathrm{Cu}(\mathrm{TFA})_{2} \bullet \mathrm{H}_{2} \mathrm{O}(2.8 \mathrm{mg} 0.010 \mathrm{mmol}, 5 \mathrm{~mol} \%)$, 9azajulolidine ( $7.0 \mathrm{mg}, 0.040 \mathrm{mmol}$ ) and $1 \mathrm{~mL}$ DCE. The initial mixture was stirred vigorously with a stir bar $(600 \mathrm{rpm})$ under air for $5 \mathrm{~min}$ before hydrazone was added. In a $4 \mathrm{~mL}$ scintillation vial, ((4-nitrophenyl)(phenyl)methylene)hydrazine ( $48 \mathrm{mg}, 0.2 \mathrm{mmol}, 1.0$ equiv) was dissolved in $1.0 \mathrm{~mL}$ of DCE. The hydrazone/DCE solution was then transferred by syringe in one portion to the initial mixture of $\mathrm{Cu}(\mathrm{TFA})_{2} \cdot \mathrm{H}_{2} \mathrm{O} / \mathrm{DCE}$ solution. The reaction was stirred for $0.5 \mathrm{~h}$ before next step.

A $20 \mathrm{~mL}$ scintillation vial equipped with a stir bar was flame dried under vacuum. After cooling down, the vail was charged with $\mathrm{Rh}_{2}(S \text {-PTAD })_{4}(2.8 \mathrm{mg}, 1.0 \mathrm{~mol} \%, 0.002 \mathrm{mmol})$, then flushed with nitrogen for 3 times and the nitrogen balloon was left on the septum. Then HFIP ( $0.42 \mathrm{~mL}$, 20 equiv, $4.0 \mathrm{mmol})$, styrene $(104.2 \mathrm{mg}, 115 \mu \mathrm{L}, 5.0$ equiv, $1.0 \mathrm{mmol})$ and $2.0 \mathrm{~mL}$ sparged DCE (sparged with nitrogen for $2 \mathrm{~h}$ before use) were added sequentially via syringe, the mixture was stirred at $600 \mathrm{rpm}$ for $10 \mathrm{~min}$ before crude diazo compound $\mathbf{2 3}$ injection. The crude diazo compound mixture from copper-catalyzed oxidation $(\sim 1.5 \mathrm{~mL})$ was added by syringe to the styrene $/ \mathrm{Rh}_{2}(S \text {-PTAD })_{4} / \mathrm{HFIP}$ solution in one portion. The reaction was then stirred $1 \mathrm{~h}$ under nitrogen at $23{ }^{\circ} \mathrm{C}$. After completion the solution was concentrated under rotovap and purified by flash column chromatography $\left(0 \%\right.$, then $5 \%-15 \% \mathrm{Et}_{2} \mathrm{O}$ in Hexanes). The product was obtained as a mixture of diastereomers as a white solid (34 mg, $56 \%$ yield, $2: 1 \mathrm{dr}, 94 \%$ ee).

Spectroscopic data matched that previously found in the literature. ${ }^{3}$

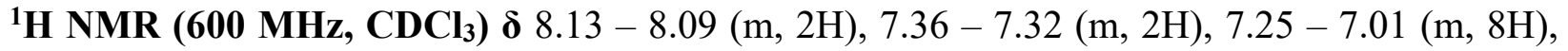
$6.86-6.83(\mathrm{~m}, 2 \mathrm{H}), 2.89(\mathrm{dd}, J=9.1,6.8 \mathrm{~Hz}, 1 \mathrm{H}), 2.13(\mathrm{dd}, J=6.8,5.7 \mathrm{~Hz}, 1 \mathrm{H}), 1.90(\mathrm{dd}, J=$ 9.1, $5.7 \mathrm{~Hz}, 1 \mathrm{H})$. 
HPLC (ADH column, hexane, $1.0 \mathrm{~mL} \mathrm{~min}^{-1} 0.5 \mathrm{mg} \mathrm{mL}^{-1} 30 \mathrm{~min}$, UV $230 \mathrm{~nm}$ ) retention times of 12.65 min (major) and 13.55 min (minor) $94 \%$ ee with $\mathrm{Rh}_{2}(S$-PTAD) 4 .

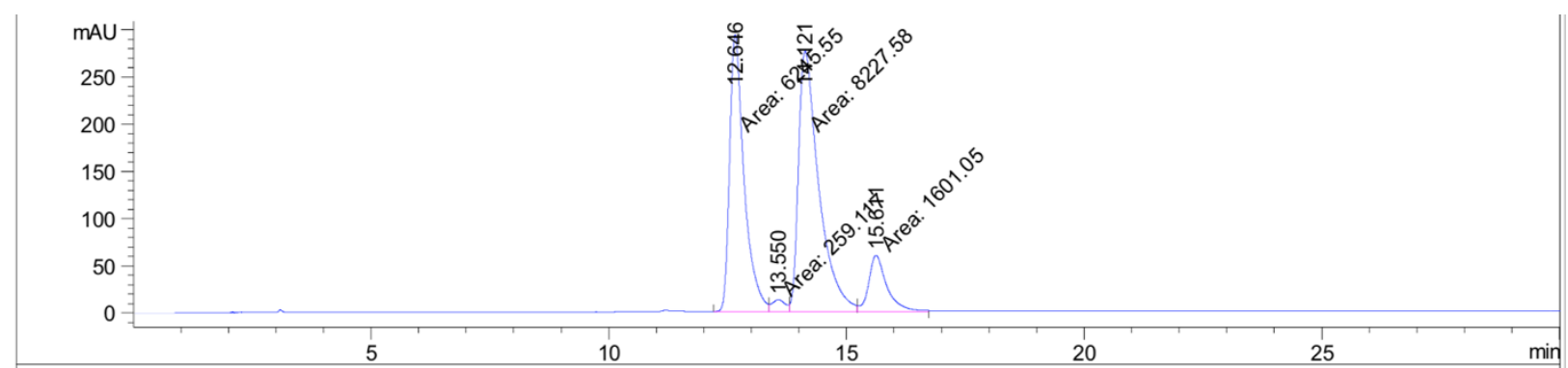

\begin{tabular}{|c|c|c|c|c|c|c|}
\hline $\begin{array}{c}\text { Peak } \\
\quad \#\end{array}$ & $\begin{array}{c}\text { RetTime } \\
\text { [min] }\end{array}$ & Type & $\begin{array}{l}\text { Width } \\
\text { [min] }\end{array}$ & $\begin{array}{c}\text { Area } \\
{\left[\mathrm{mAU}^{\star} \mathrm{s}\right]}\end{array}$ & $\begin{array}{l}\text { Height } \\
\text { [mAU] }\end{array}$ & $\begin{array}{c}\text { Area } \\
\text { \% }\end{array}$ \\
\hline \multicolumn{7}{|c|}{$----|-------|----|-------|----------|----------|--------\mid$} \\
\hline 1 & 12.646 & MF & 0.3549 & 6245.55225 & 293.26422 & 38.2382 \\
\hline 2 & 13.550 & $\mathrm{MF}$ & 0.3376 & 259.11688 & 12.79360 & 1.5864 \\
\hline 3 & 14.121 & $\mathrm{MF}$ & 0.4968 & 8227.58008 & 276.01035 & 50.3730 \\
\hline 4 & 15.611 & FM & 0.4466 & 1601.05176 & 59.75366 & 9.8024 \\
\hline Total & 1s: & & & $1.63333 \mathrm{e} 4$ & 641.82182 & \\
\hline
\end{tabular}

\section{Racemic (with $\left.\mathrm{Rh}_{2}(\mathrm{OAc})_{4}\right)$ :}

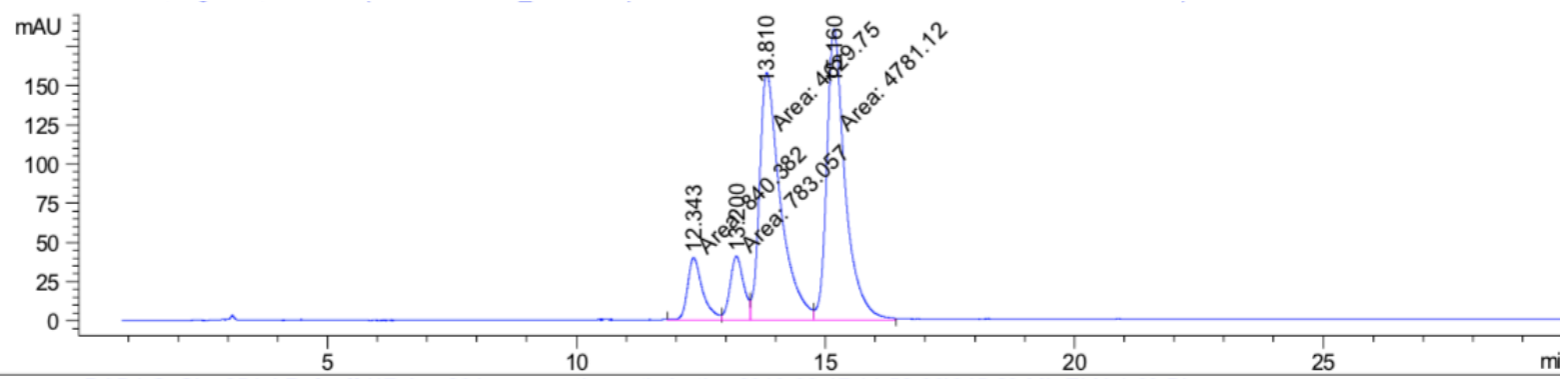

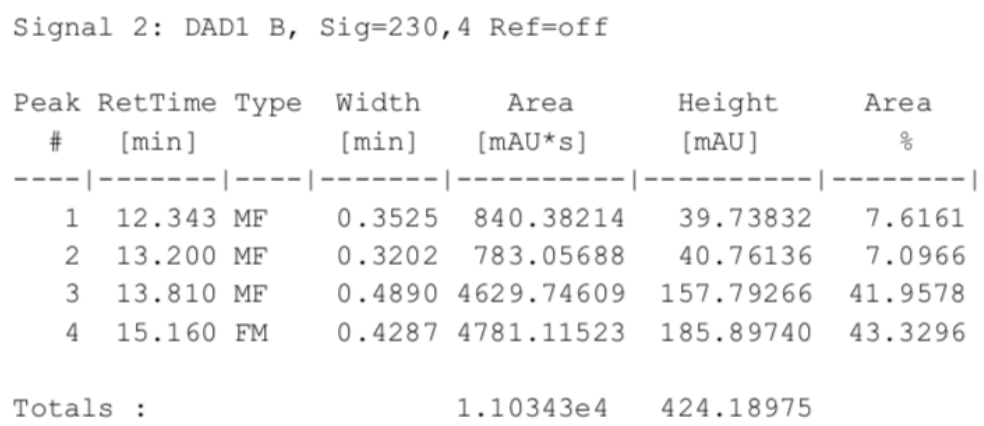




\section{Reference}

1. Rackl, D.; Yoo, C.-J.; Jones, C. W.; Davies, H. M. L. Synthesis of Donor/Acceptor-Substituted Diazo Compounds in Flow and Their Application in Enantioselective Dirhodium-Catalyzed Cyclopropanation and C-H Functionalization Org. Lett. 2017, 19, 3055-3058.

2. Nicolle, S. M.; Moody, C. J. Potassium $N$-Iodo $p$-Toluenesulfonamide (TsNIK, Iodamine-T): A New Reagent for the Oxidation of Hydrazones to Diazo Compounds Chem. Eur. J. 2014, 20, 4420-4425.

3. Lee, M.; Ren, Z.; Musaev, D. G.; Davies, H. M. L. Rhodium-Stabilized Diarylcarbenes Behaving as Donor/Acceptor Carbenes ACS Catal., 2020, 10, 6240.

4. Perusquía-Hernández, C.; Lara-Issasi, G. R.; Frontana-Uribe, B. A.; Cuevas-Yañez. E. Synthesis and esterification reactions of aryl diazomethanes derived from hydrazone oxidations catalyzed by TEMPO Tetrahedron Lett. 2013, 54, 33023305 .

5. Wei, B.; Sharland, J. C.; Lin, P.; Wilkerson-Hill, S. M.; Fullilove, F. A.; McKinnon, S.; Blackmond, D. G.; Davies, H. M. L. In Situ Kinetic Studies of Rh(II)-Catalyzed Asymmetric Cyclopropanation with Low Catalyst Loadings ACS Catal. 2020, 10, 1161-1170.

6. Reddy, R. P.; Lee, G. H.; Davies, H. M. L., Dirhodium Tetracarboxylate Derived from Adamantylglycine as a Chiral Catalyst for Carbenoid Reactions Organic Letters 2006, 8 (16), 3437-3440.

7. Alonazy, H. S.; AL-Hazimi, H. M. A.; Korraa, M. M. S. Novel 5,6-bis-(4-substitutedphenyl)-2H(3)-pyridazinones: Synthesis and reactions Arab. J. Chem. 2009, 2, 101-108.

8. Guptill, D. M.; Davies, H. M. L. 2,2,2-Trichloroethyl Aryldiazoacetates as Robust Reagents for the Enantioselective CH Functionalization of Methyl Ethers J. Am. Chem. Soc. 2014, 136, 17718-17721.

9. Bess, E. N.; Guptill, D. M.; Davies, H. M. L.; Sigman, M. S. Using IR vibrations to quantitatively describe and predict siteselectivity in multivariate Rh-catalyzed C-H functionalization, Chem. Sci. 2015, 6, 3057-3062.

10. Hahn, N. D.; Nieger, M.; Dötz, K. H. Efficient and regioselective chromium(0)-catalyzed reaction of 2-substituted furans with diazo compounds: stereoselective synthesis of (2E,4Z)-2-aryl-hexadienedioic acid diesters J. Organomet. Chem. 2004, 689, 2662-2673.

11. Fu, L.; Mighion, J. D.; Voight, E. A.; Davies, H. M. L. Synthesis of 2,2,2,-Trichloroethyl Aryl- and Vinyldiazoacetates by Palladium-Catalyzed Cross-Coupling Chem. Eur. J. 2017, 23, 3272-3275.

12. Peng, C.; Cheng, J.; Wang, J. Palladium-Catalyzed Cross-Coupling of Aryl or Vinyl Iodides with Ethyl Diazoacetate $J$. Am. Chem. Soc. 2007, 129, 8708-8709.

13. Davis, O. A.; Croft, R. A.; Bull, J. A. Synthesis of diversely functionalised 2,2-disubstituted oxetanes: fragment motifs in new chemical space Chem. Commun. 2015, 51, 15446-15449.

14. Marti, C.; Carreira, E. M. Total Synthesis of (-)-Spirotryprostatin B: Synthesis and Related Studies J. Am. Chem. Soc. 2005, 127, 11505-11515.

15. Uekusa H.; Ohba, S.; Saito, Y.; Kato, M.; Tokii, T.; Muto, Y Structural comparison between dimeric copper(II) formate and acetate in pyridine and urea adducts Acta Cryst. 1989, 45, 377-380.

16. Mennen, S. M. et al. The Evolution of High-Throughput Experimentation in Pharmaceutical Development and Perspectives on the Future Org. Process Res. Dev. 2019, 23, 1213-1242.

17. Wei, B.; Sharland, J. C.; Lin, P.; Wilkerson-Hill, S. M.; Fullilove, F. A.; McKinnon, S.; Blackmond, D. G.; Davies, H. M. L. In Situ Kinetic Studies of Rh(II)-Catalyzed Asymmetric Cyclopropanation with Low Catalyst Loadings ACS Catal. 2020, 10, 1161-1170.

18. Hirayama, T.; Ueda, S.; Okada, T.; Tsurue, N.; Okuda, K.; Nagasawa, H. Facile One-Pot Synthesis of $[1,2,3]$ Triazolo[1, 5-a]Pyridines from 2-Acylpyridines by Copper(II)-Catalyzed Oxidative N-N Bond Formation Chem. Eur. J. 2014, 20, 4156-4162.

19. Yoo, C. J.; Rackl, D.; Liu, W.; Hoyt, C. B.; Pimentel, B.; Lively, R. P.; Davies, H. M. L.; Jones, C. W. An ImmobilizedDirhodium Hollow-Fiber Flow Reactor for Scalable and Sustainable C-H Functionalization in Continuous Flow Angew. Chem., Int. Ed. 2018, 57, 10923-10927. 


\section{Crude NMR Spectra}

This section includes some selected examples of the crude ${ }^{1} \mathrm{H}-\mathrm{NMR}$ spectra of the reactions in the condition optimization table (Table 1).
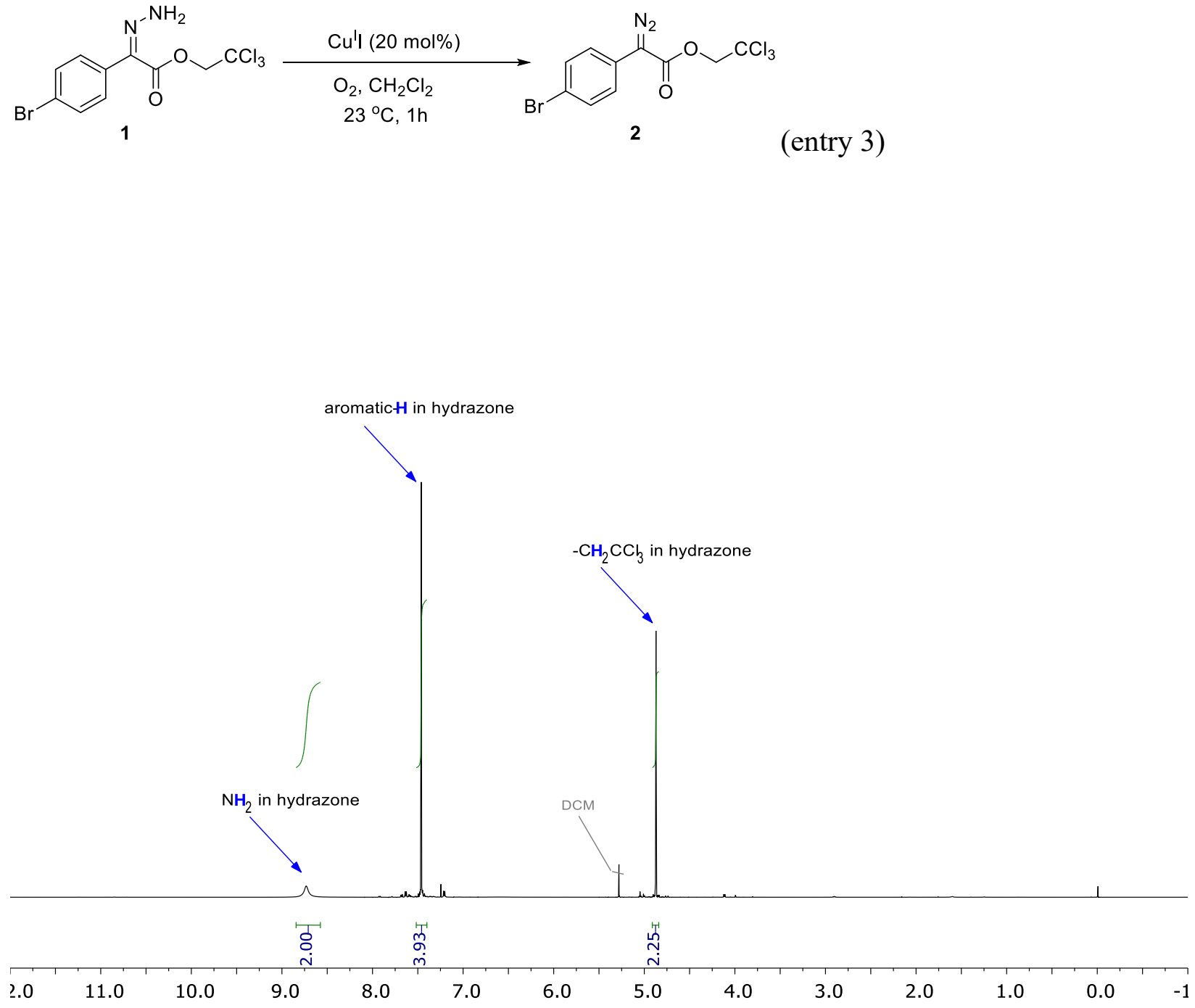


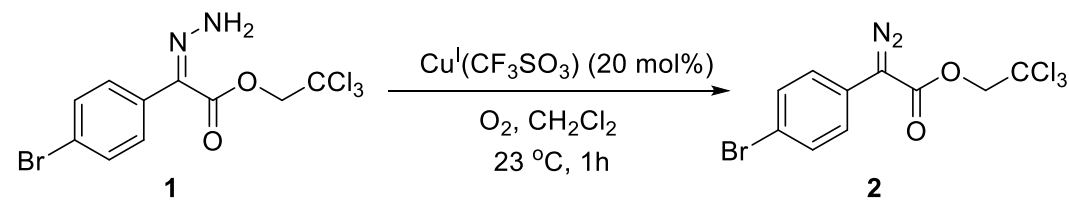

1

(entry 6)

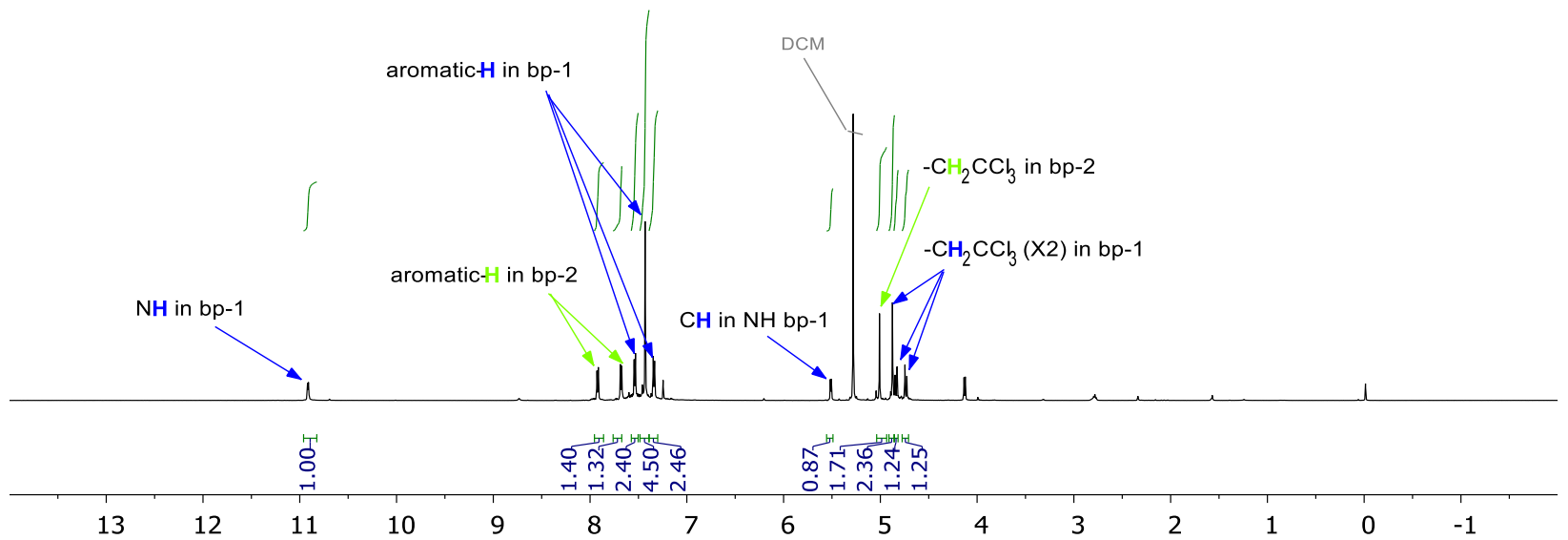


<smiles>N=C(C(=O)OCC(Cl)(Cl)Cl)c1ccc(Br)cc1</smiles>

1

2

(entry 7)

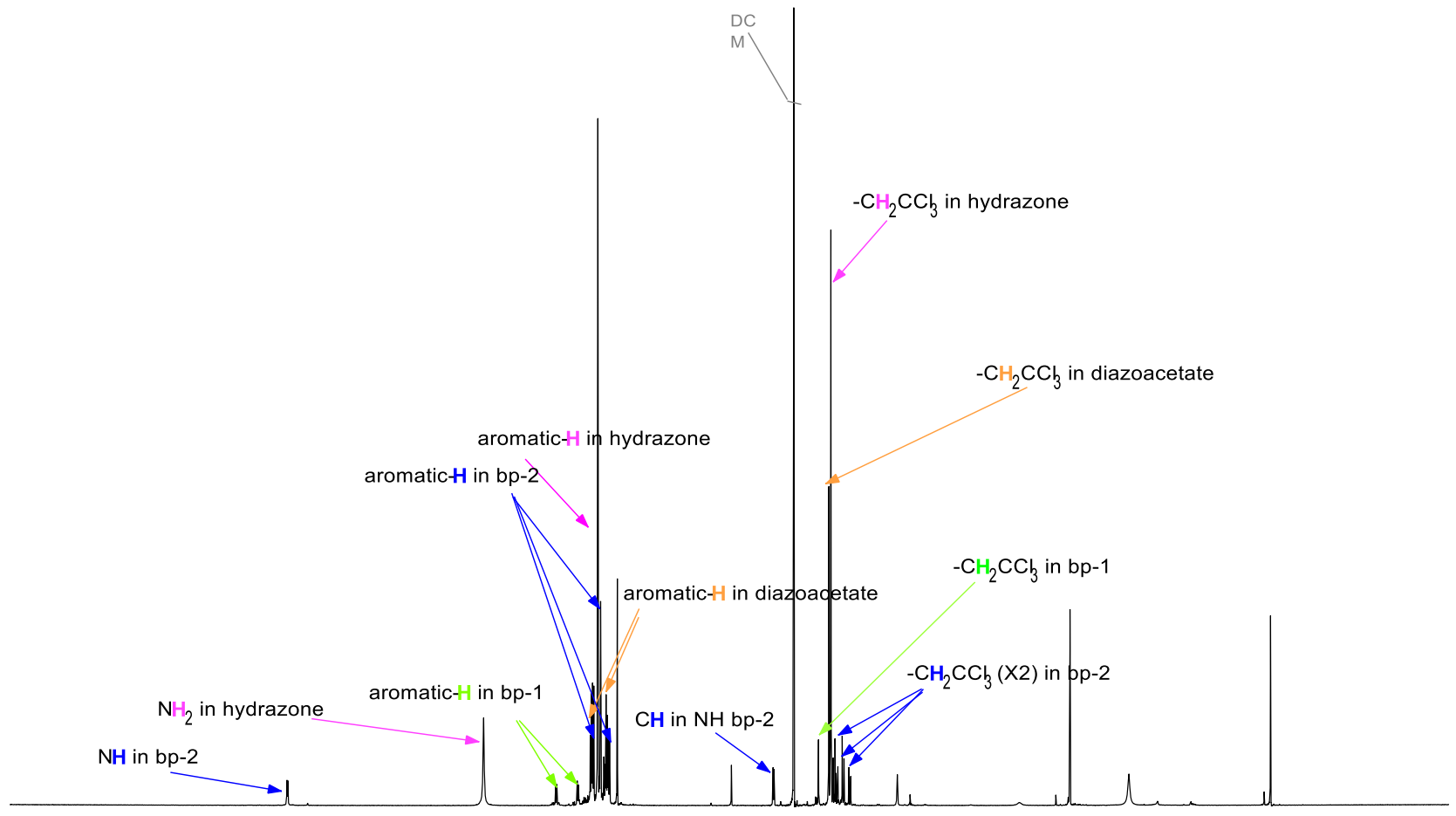

$13 \quad 12$

$10-9-1$

$8+7$

$\begin{array}{lllllll}5 & 4 & 3 & 2 & 1 & 0 & -1\end{array}$




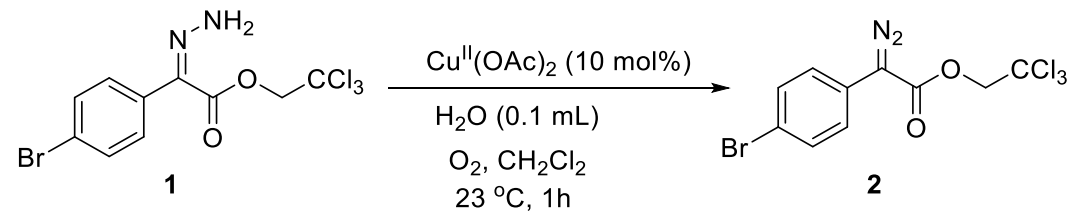

(entry 8)

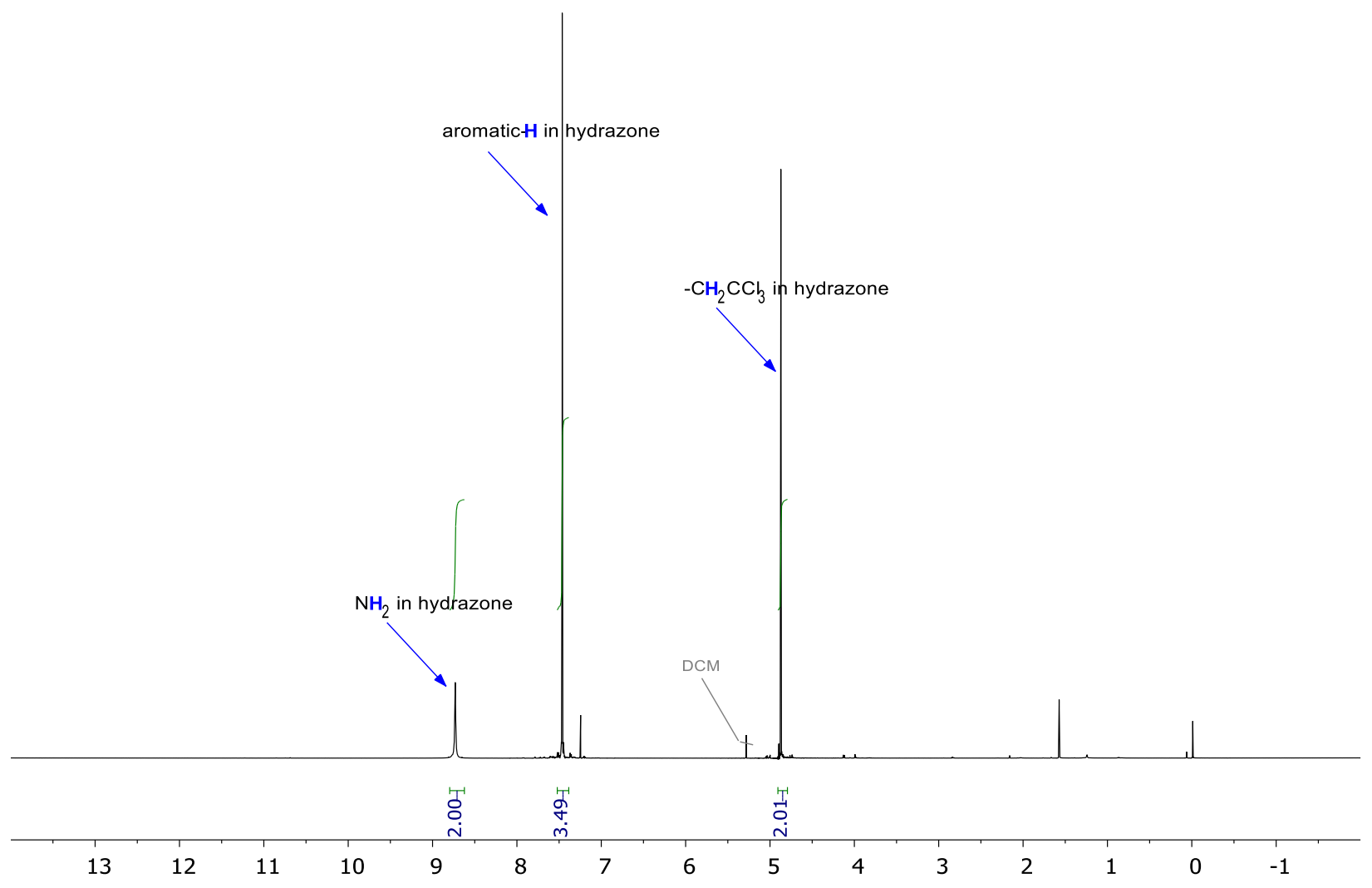




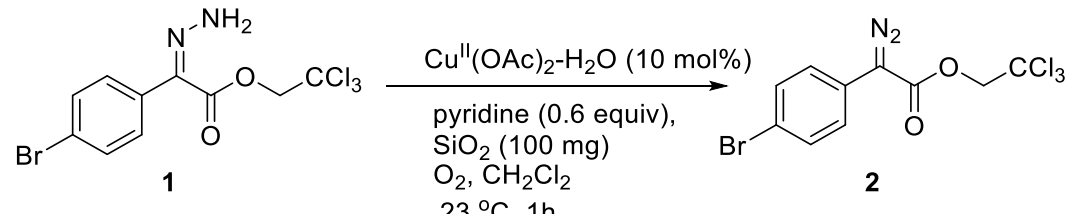

$2{ }^{\circ} \mathrm{C}, 1 \mathrm{~h}$

(entry 15)

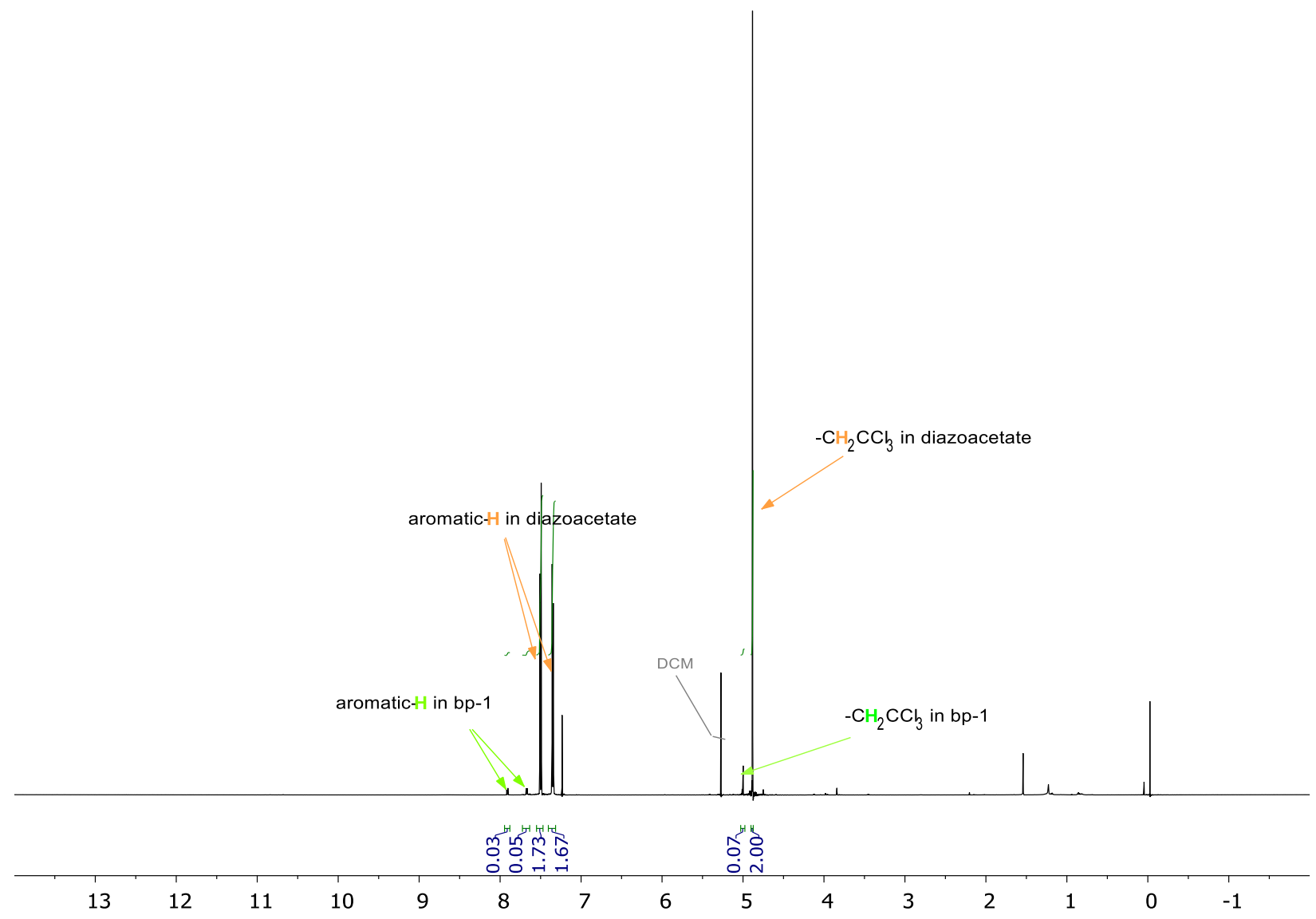




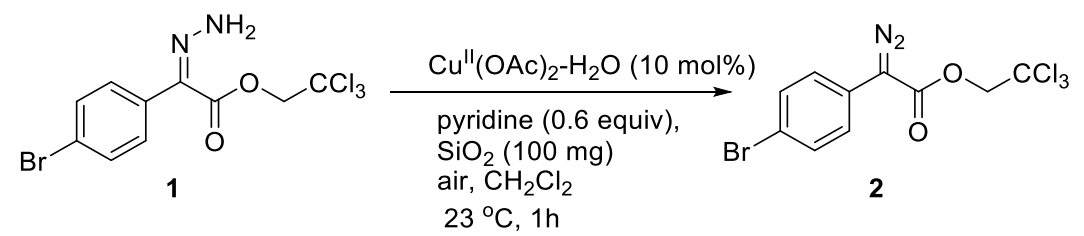

(entry 16)

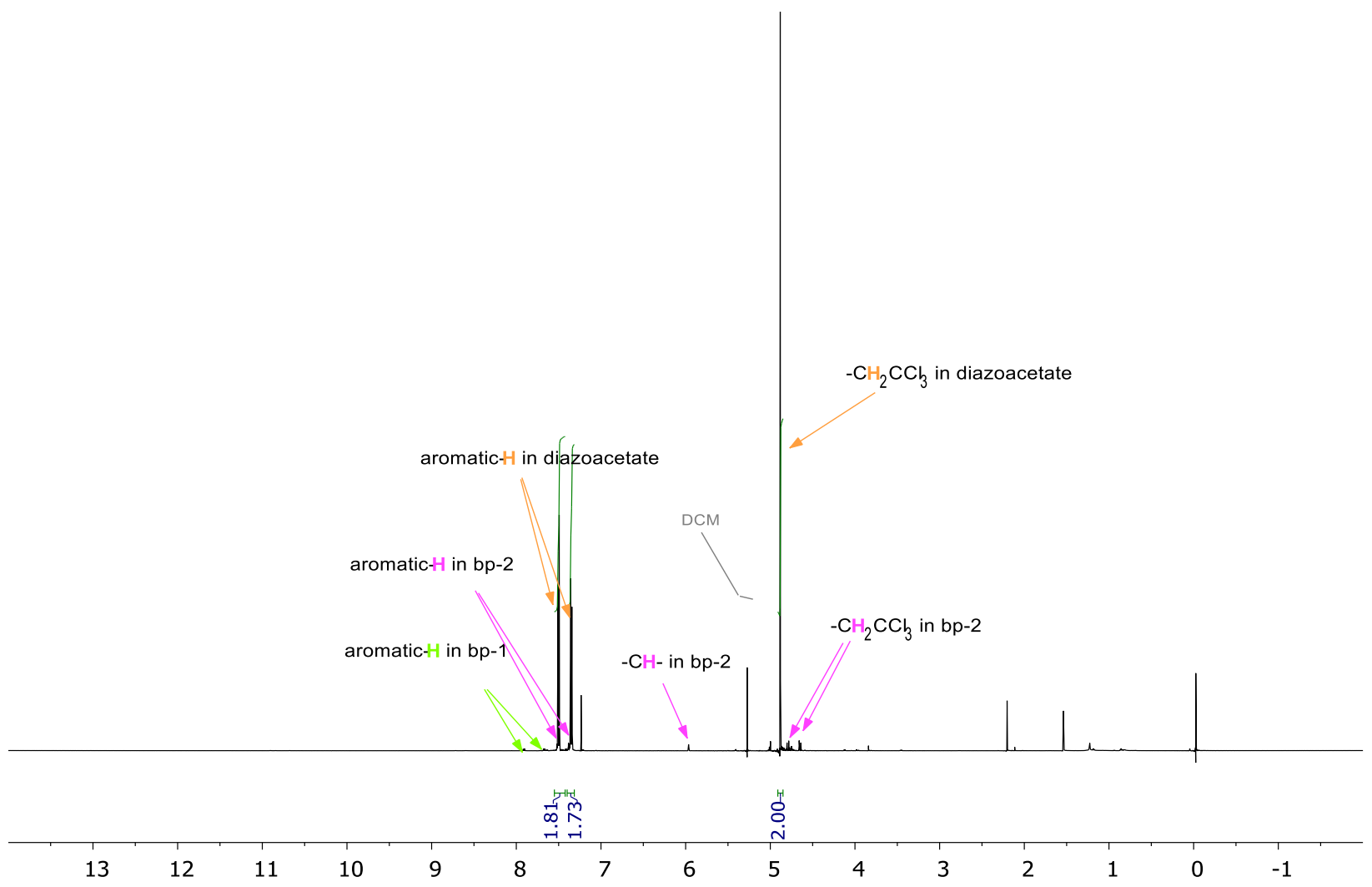




\section{Characterization NMR Spectra}<smiles>O=C(OCC(F)(F)F)C(=O)c1ccc(Br)cc1</smiles>

${ }^{1} \mathrm{H} \mathrm{NMR}\left(600 \mathrm{MHz}, \mathrm{CDCl}_{3}\right)$
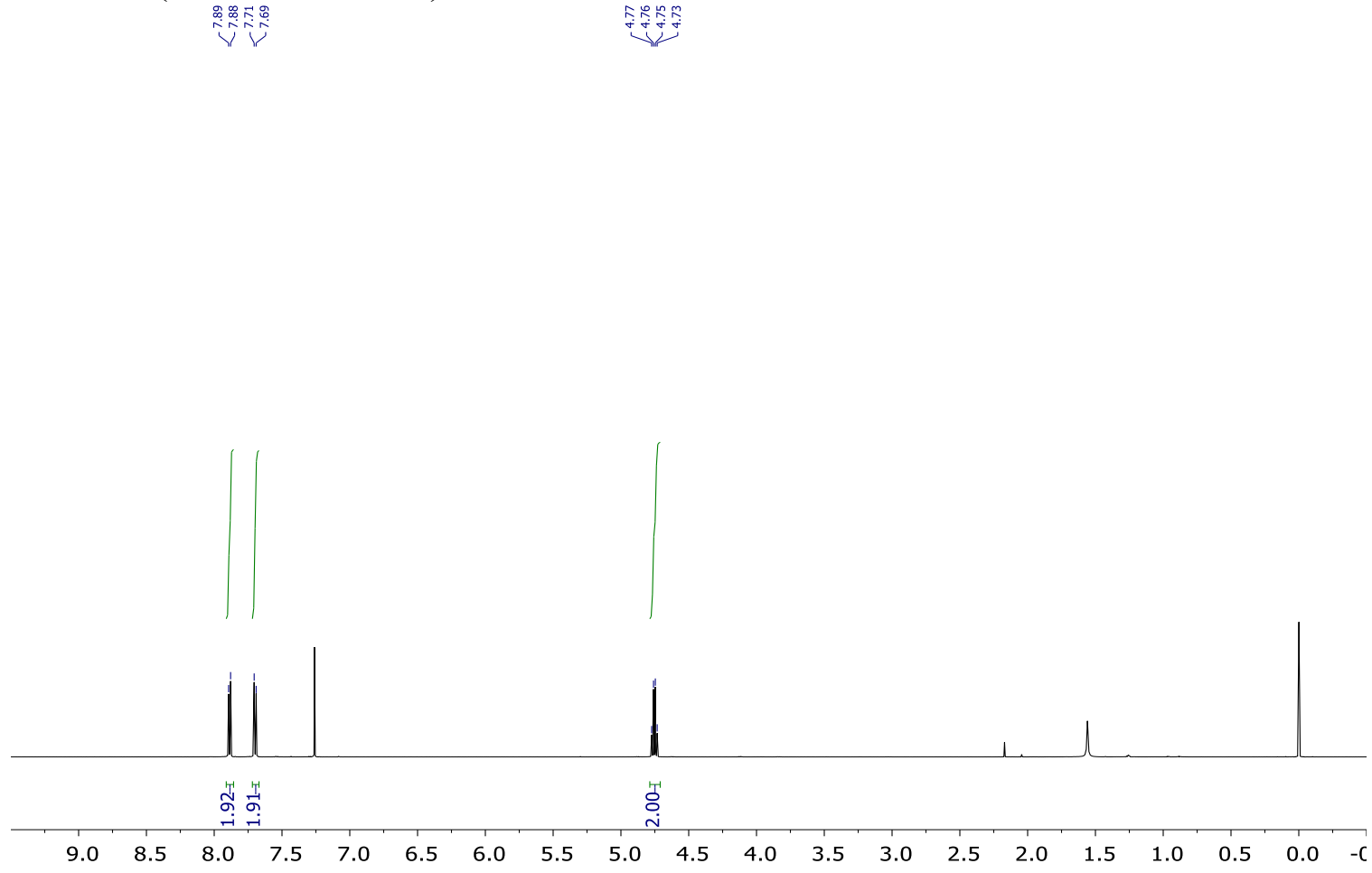

$\left.{ }^{13} \mathrm{C} \mathrm{NMR} \mathrm{(151} \mathrm{MHz,} \mathrm{CDCl}_{3}\right)$
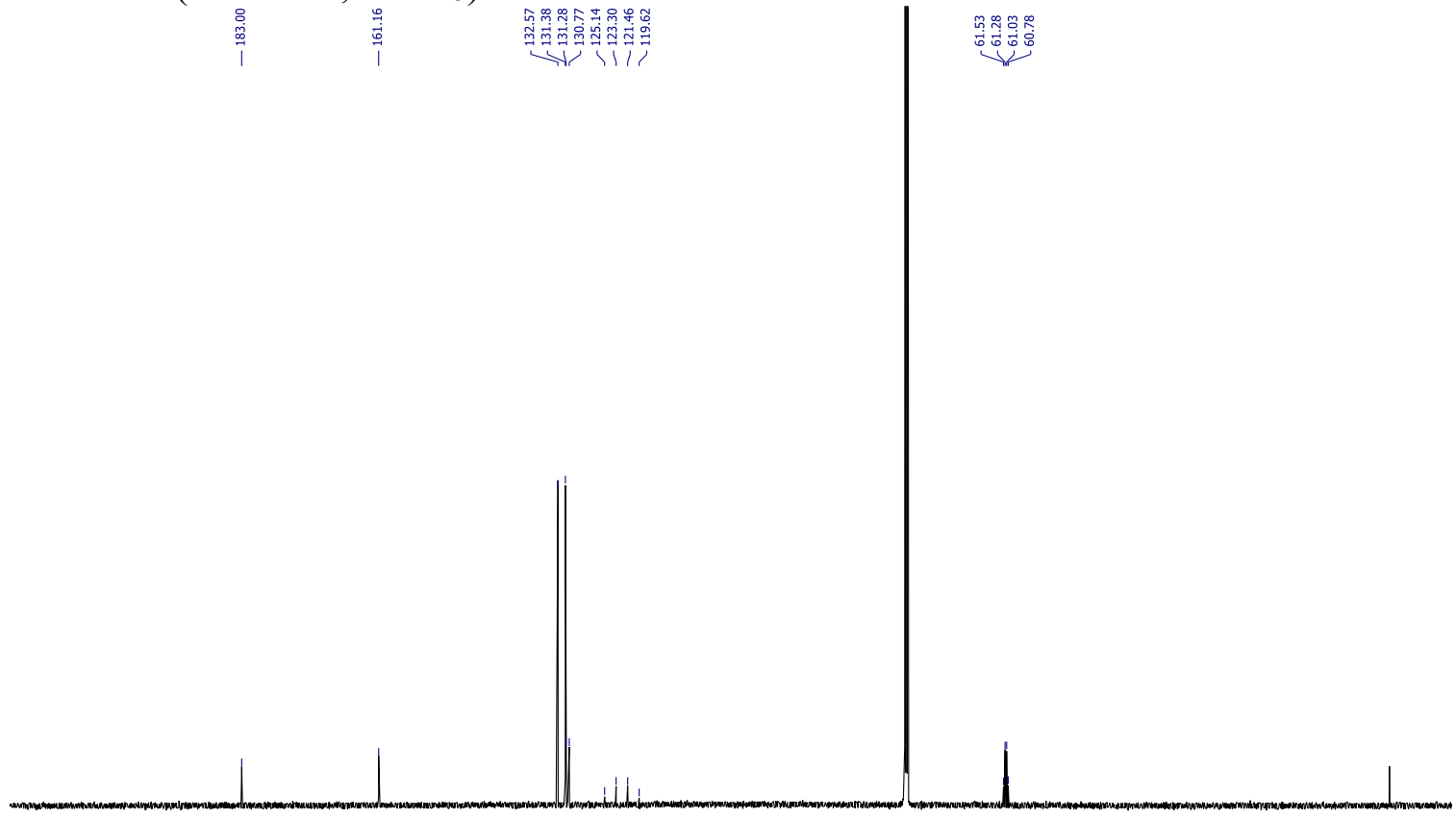

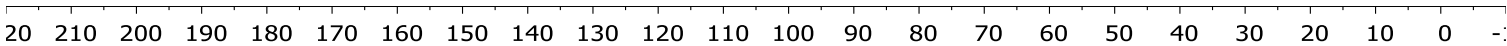


${ }^{19} \mathrm{~F}$ NMR $\left(282 \mathrm{MHz}, \mathrm{CDCl}_{3}\right)$

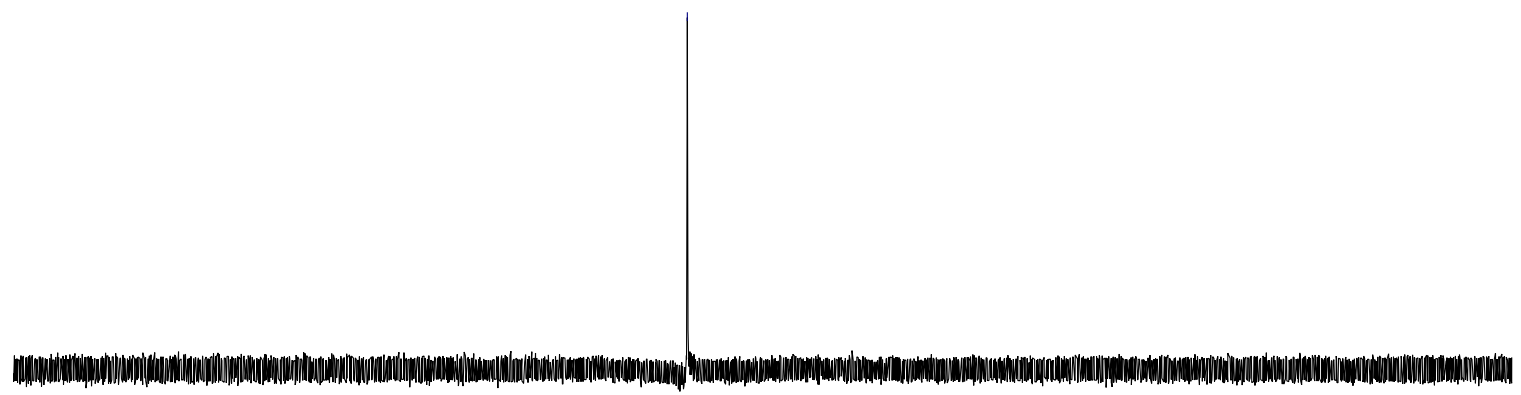

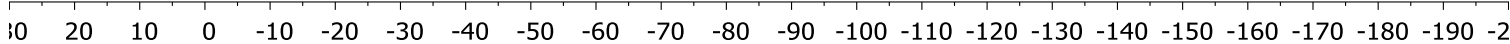


<smiles>CC(C)(C)COC(=O)C(=O)c1ccc(Br)cc1</smiles>

${ }^{1} \mathrm{H} \mathrm{NMR}\left(600 \mathrm{MHz}, \mathrm{CDCl}_{3}\right)$

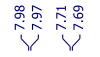
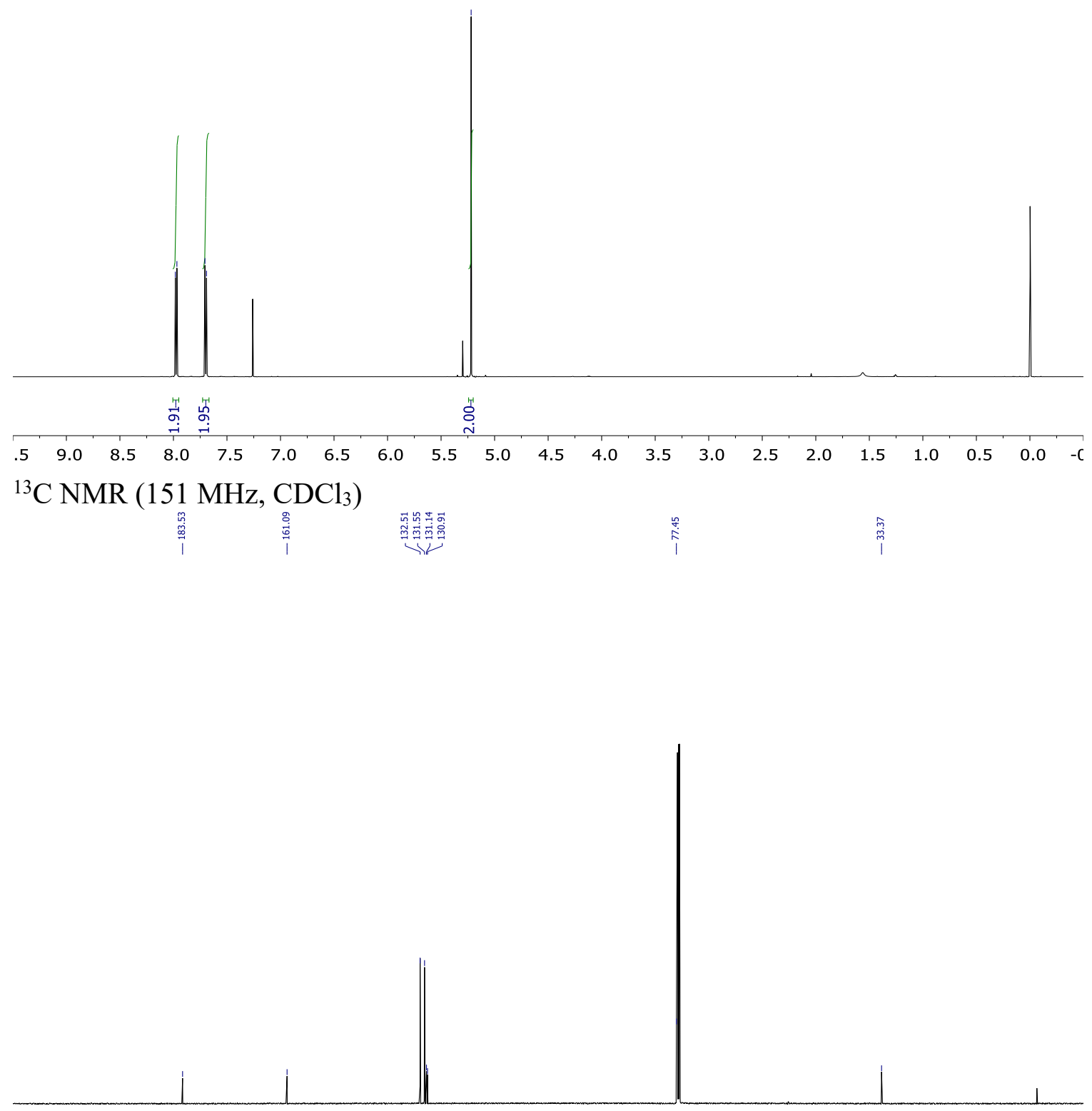

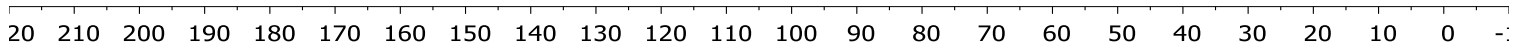


<smiles>N/N=C(\C(=O)OCC(F)(F)F)c1ccc(Br)cc1</smiles>

${ }^{1} \mathrm{H} \mathrm{NMR}\left(600 \mathrm{MHz}, \mathrm{CDCl}_{3}\right)$
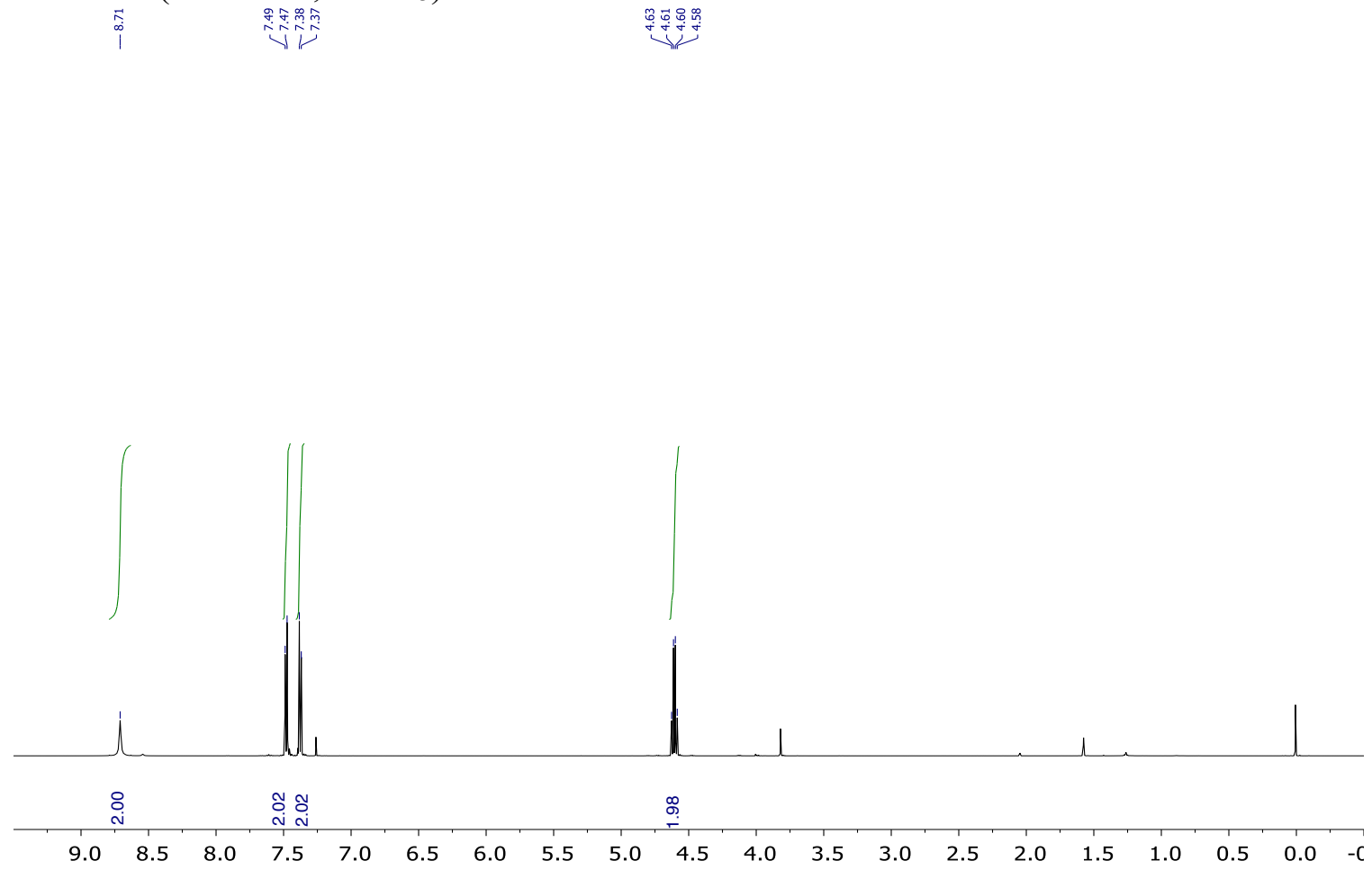

${ }^{13} \mathrm{C} \mathrm{NMR}\left(151 \mathrm{MHz}, \mathrm{CDCl}_{3}\right)$
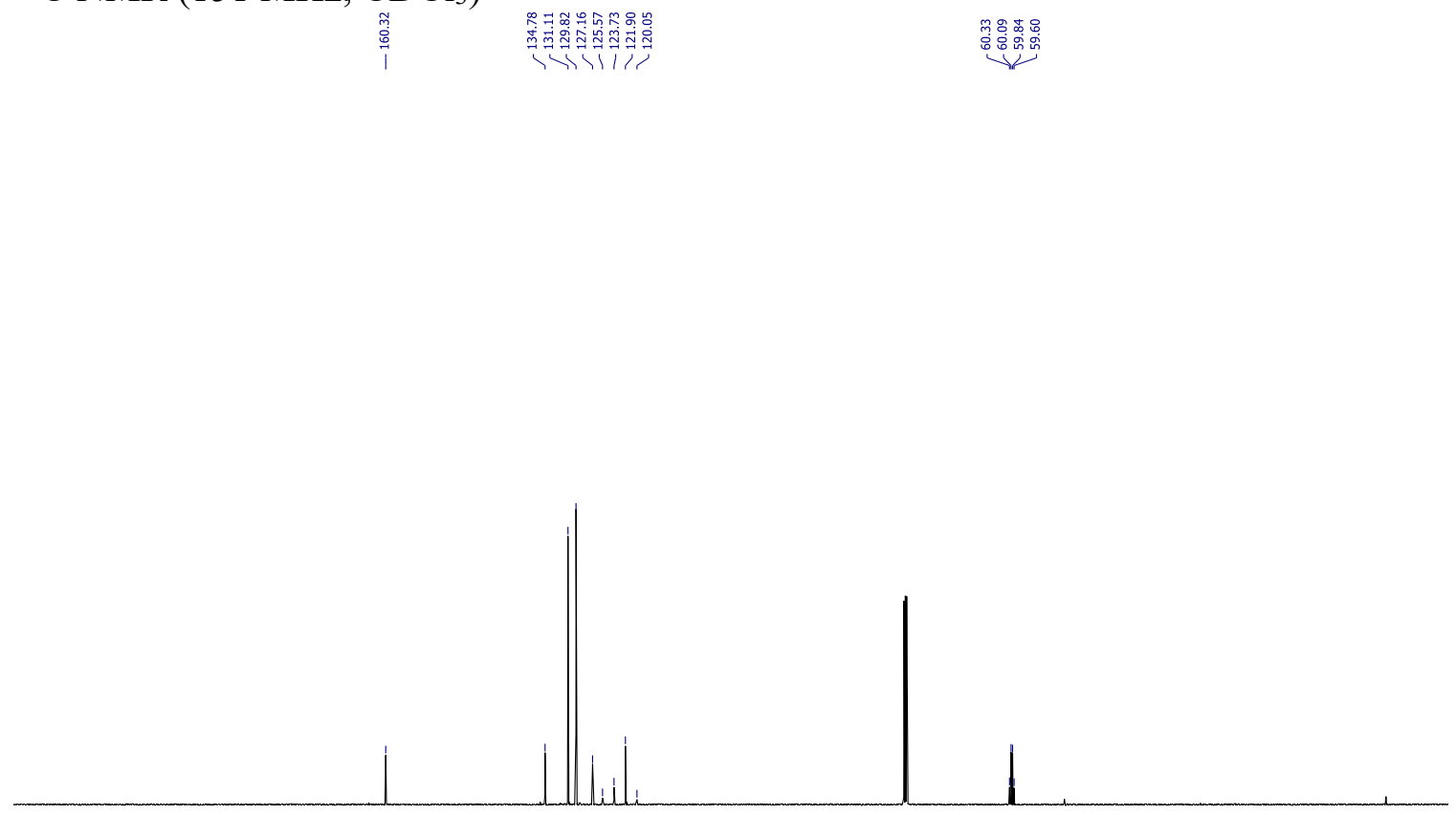

\begin{tabular}{llllllllllllllllllllllll}
\hline 20 & 210 & 200 & 190 & 180 & 170 & 160 & 150 & 140 & 130 & 120 & 110 & 100 & 90 & 80 & 70 & 60 & 50 & 40 & 30 & 20 & 10 & 0 & -1
\end{tabular} 
${ }^{19} \mathrm{~F}$ NMR $\left(282 \mathrm{MHz}, \mathrm{CDCl}_{3}\right)$
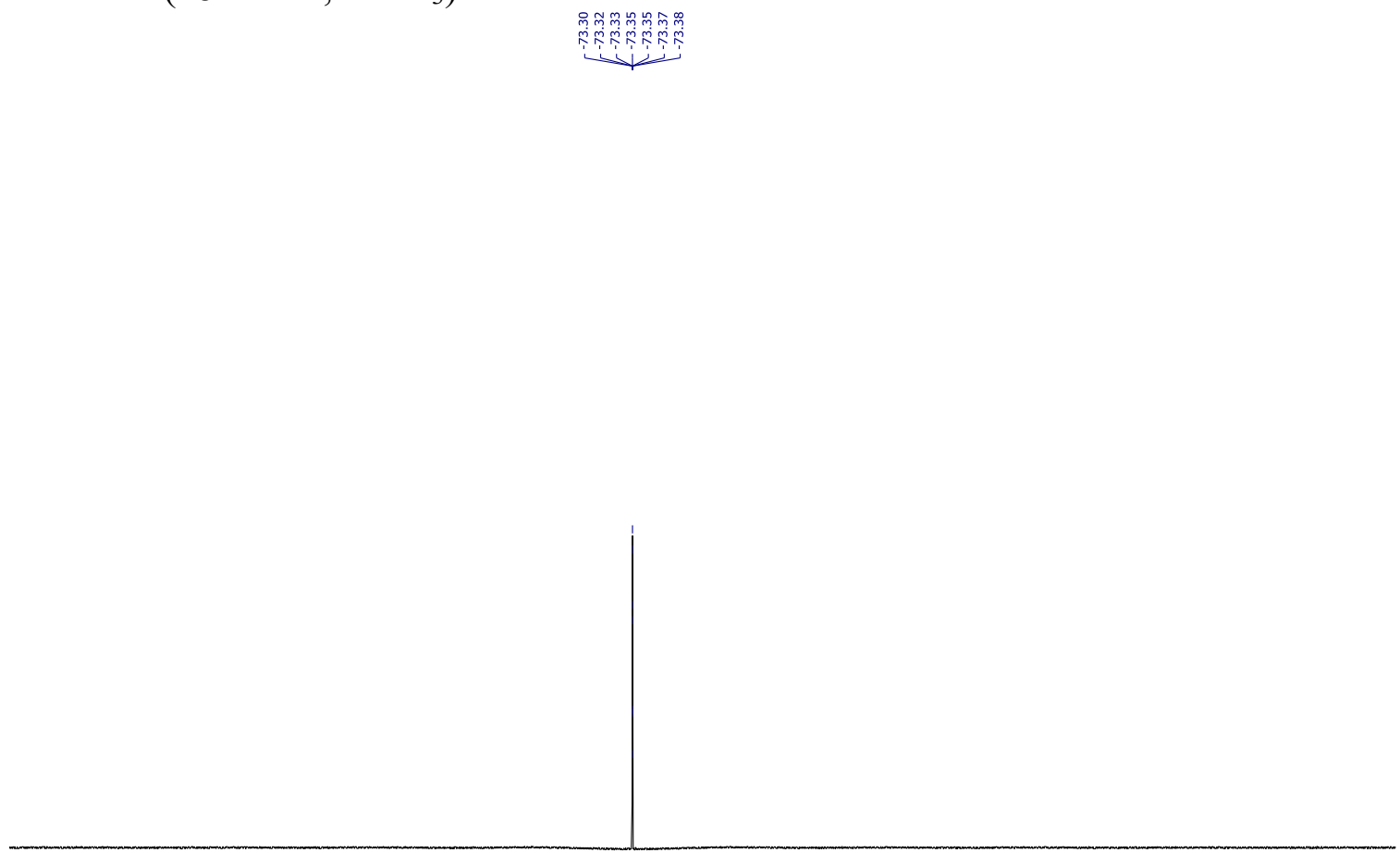

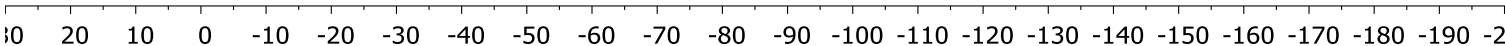


<smiles>CC(C)(C)COC(=O)C(=NN)c1ccc(Br)cc1</smiles>

${ }^{1} \mathrm{H} \mathrm{NMR}\left(600 \mathrm{MHz}, \mathrm{CDCl}_{3}\right)$

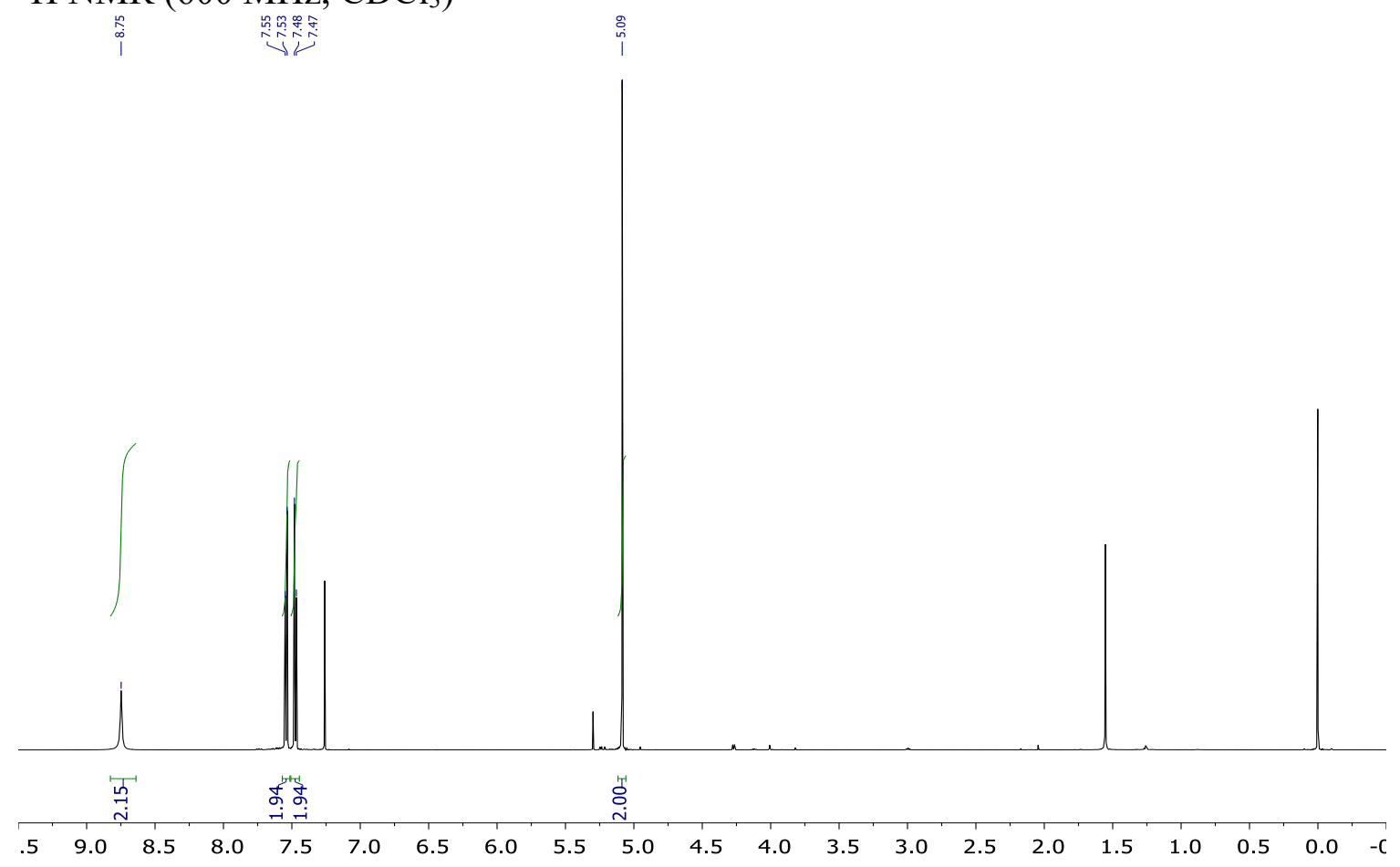
${ }^{13} \mathrm{C} \mathrm{NMR}\left(151 \mathrm{MHz}, \mathrm{CDCl}_{3}\right)$

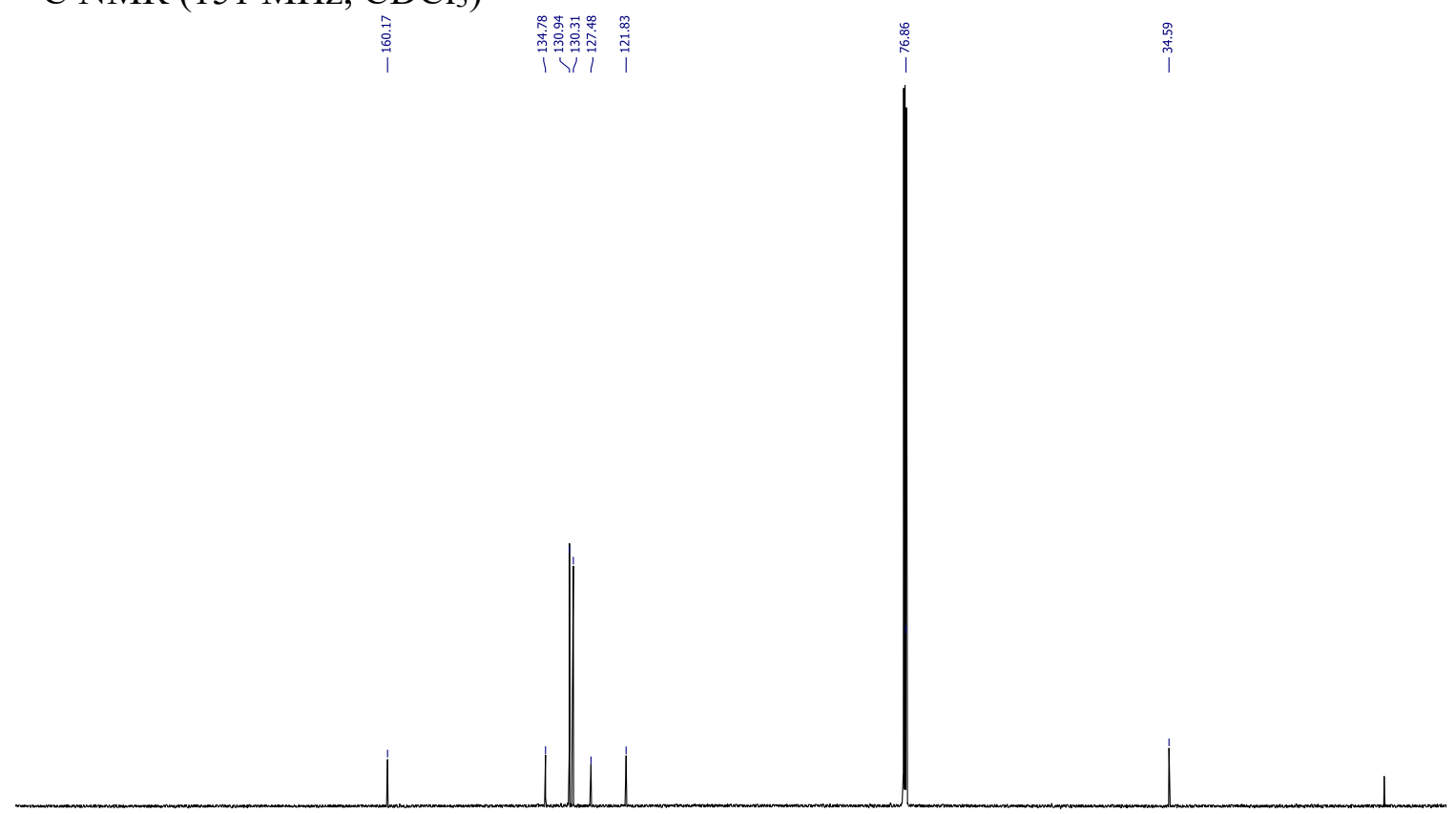

\begin{tabular}{llllllllllllllllllllllll}
\hline 20 & 210 & 200 & 190 & 180 & 170 & 160 & 150 & 140 & 130 & 120 & 110 & 100 & 90 & 80 & 70 & 60 & 50 & 40 & 30 & 20 & 10 & 0 & $-:$
\end{tabular} 
<smiles>CC(C)(C)COC(=O)/C(=N/N)c1ccc(Br)cc1</smiles>

${ }^{1} \mathrm{H} \mathrm{NMR}\left(600 \mathrm{MHz}, \mathrm{CDCl}_{3}\right)$
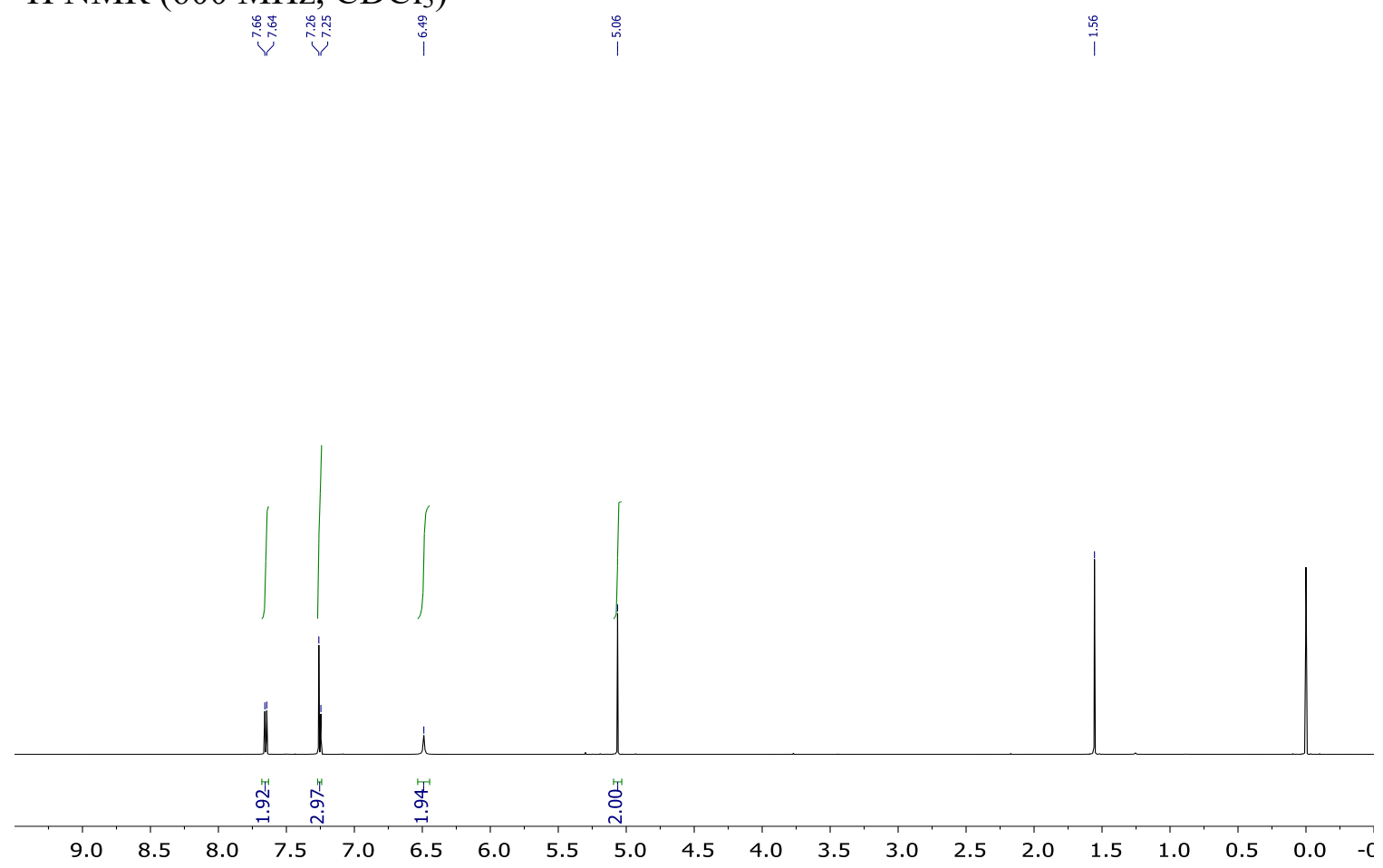

${ }^{13} \mathrm{C} \mathrm{NMR}\left(151 \mathrm{MHz}, \mathrm{CDCl}_{3}\right)$

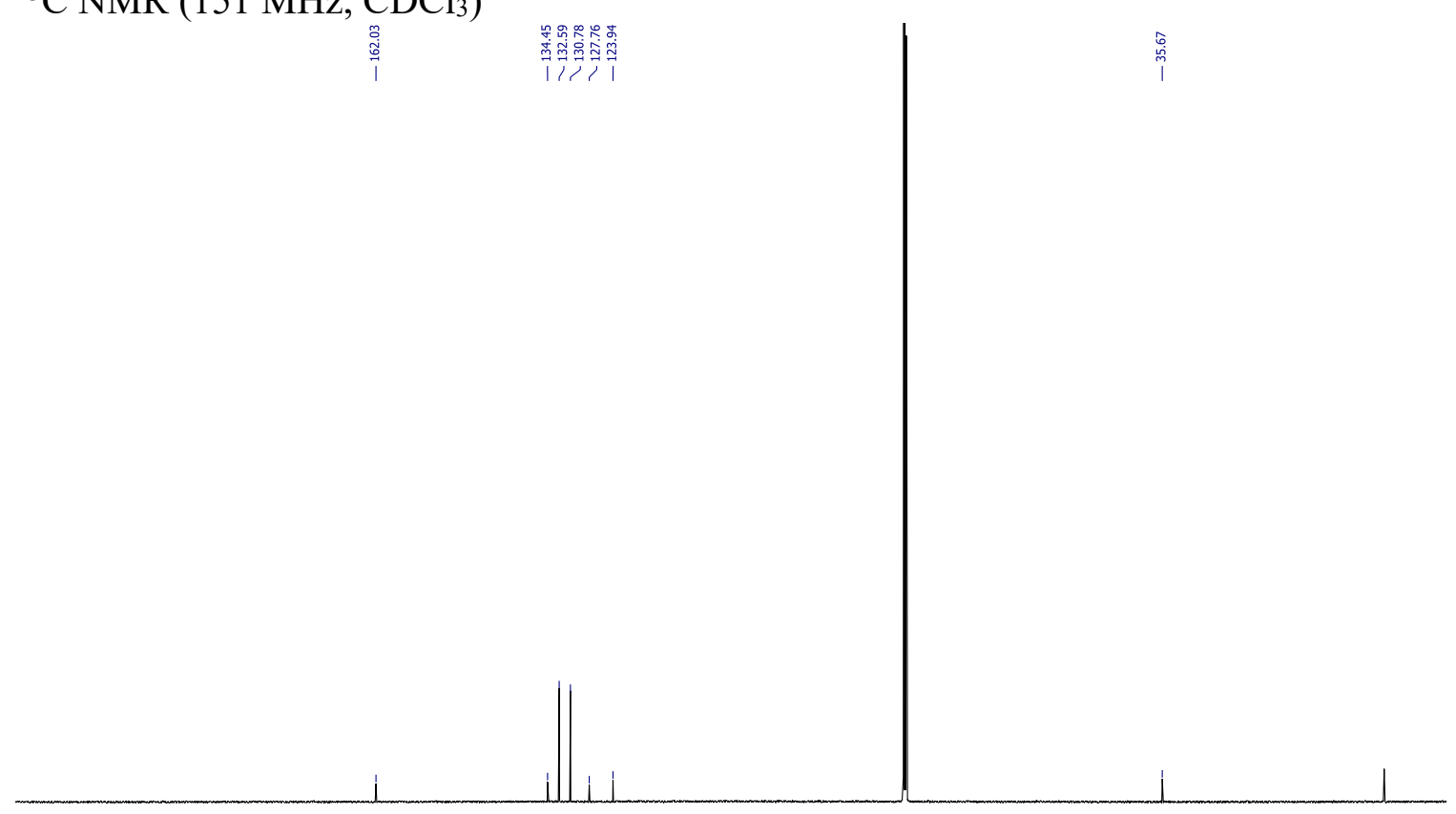

$\begin{array}{llllllllllllllllllllllllllll}20 & 210 & 200 & 190 & 180 & 170 & 160 & 150 & 140 & 130 & 120 & 110 & 100 & 90 & 80 & 70 & 60 & 50 & 40 & 30 & 20 & 10 & 0 & -:\end{array}$ 
<smiles>CCOC(=O)/C(=N\N)c1ccc([N+](=O)[O-])cc1</smiles>

${ }^{1} \mathrm{H}$ NMR (600 MHz, $\left.\mathrm{CDCl}_{3}\right)$

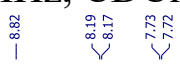

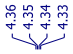
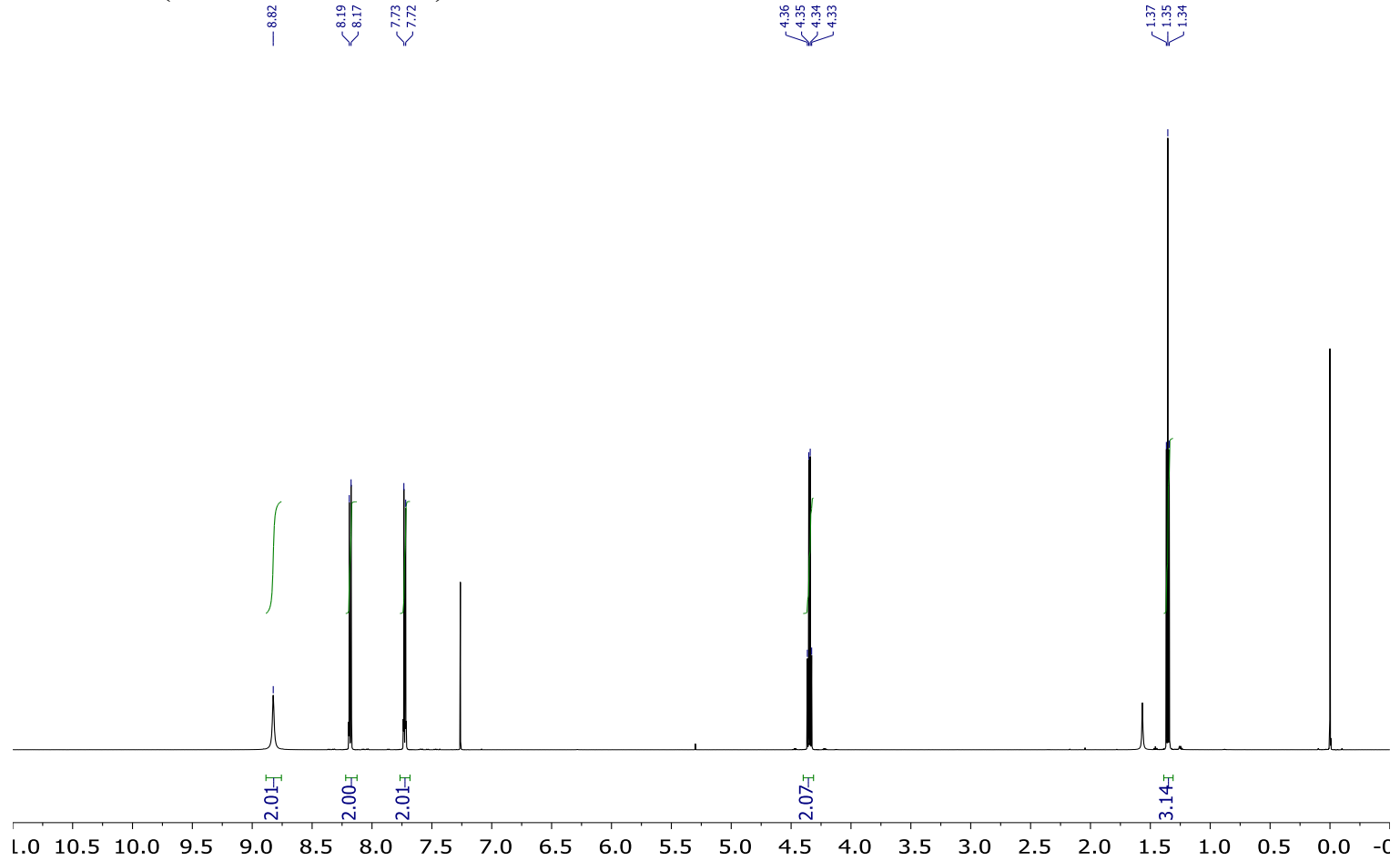

${ }^{13} \mathrm{C}$ NMR (151 MHz, $\left.\mathrm{CDCl}_{3}\right)$

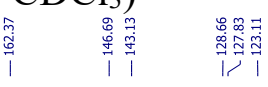
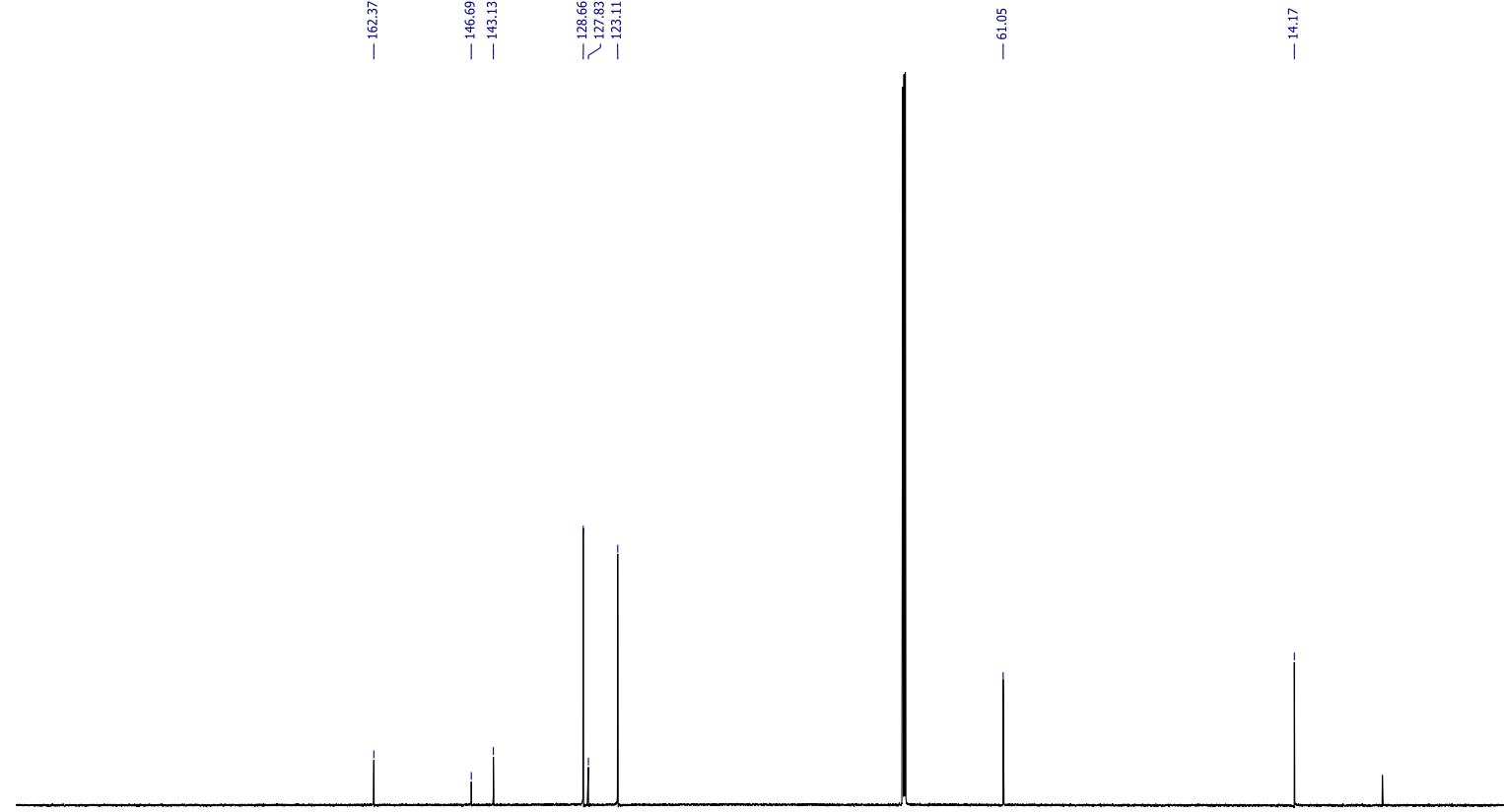

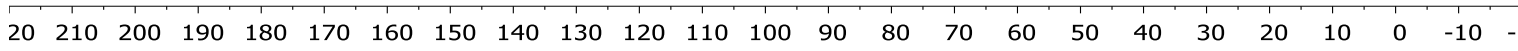


<smiles>CCOC(=O)/C(=N/N)c1ccc(F)cc1</smiles>

${ }^{1} \mathrm{H}$ NMR (400 MHz, $\mathrm{CDCl}_{3}$ )

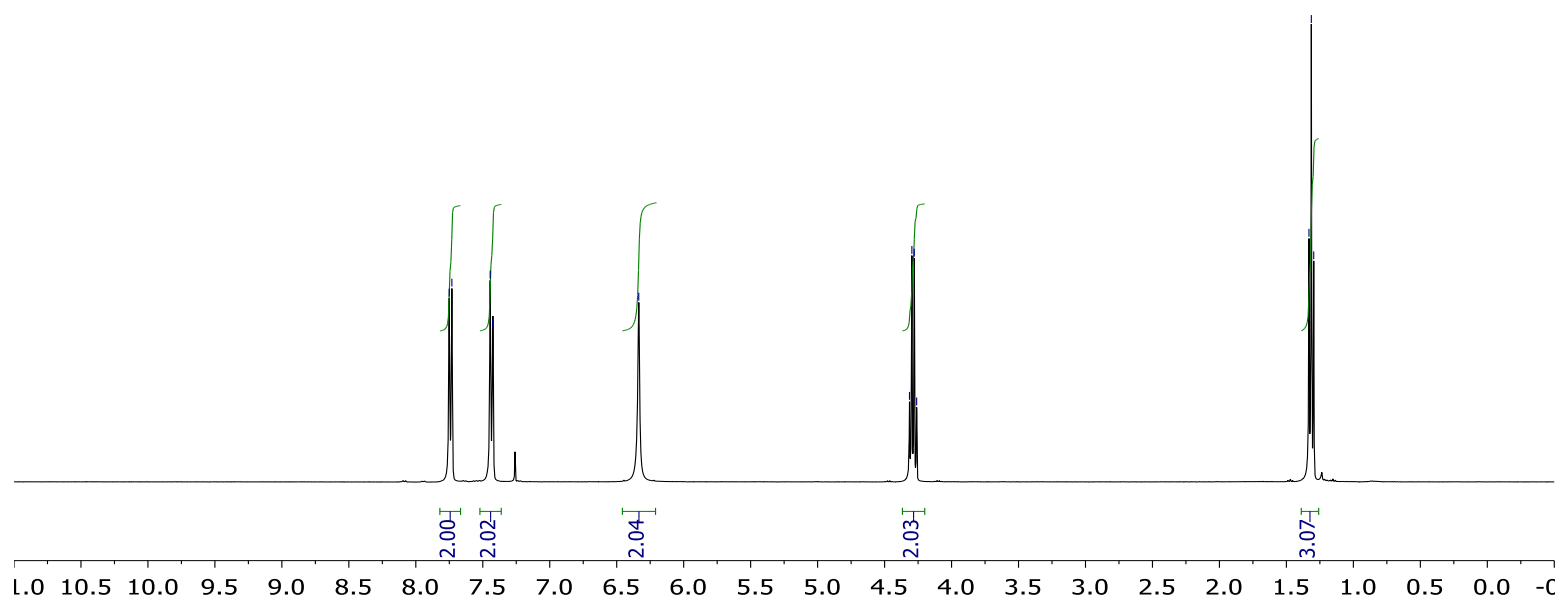

${ }^{13} \mathrm{C} \mathrm{NMR} \mathrm{(101} \mathrm{MHz,} \mathrm{CDCl}_{3}$ )

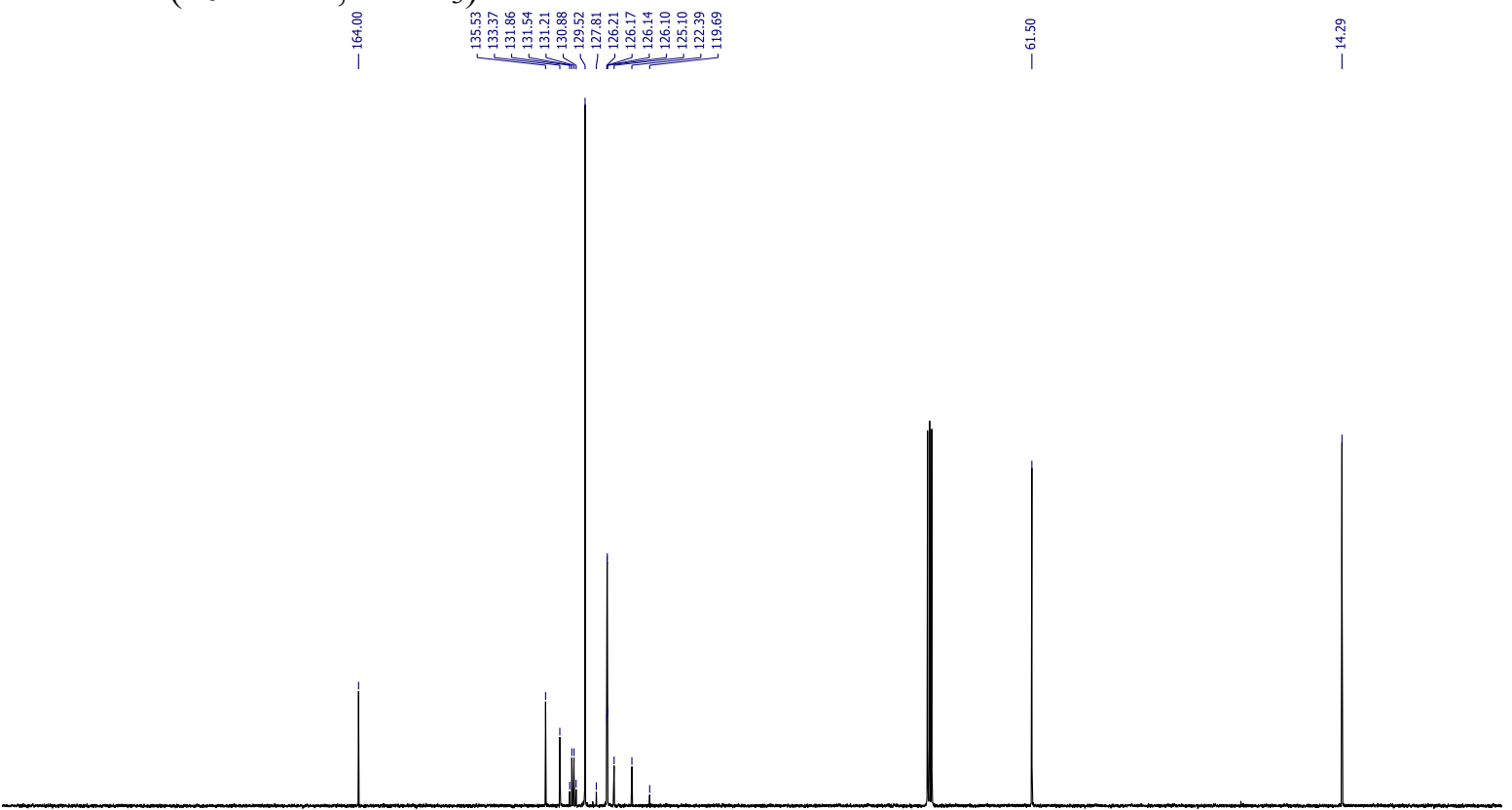

$\begin{array}{lllllllllllllllllllllll}210 & 200 & 190 & 180 & 170 & 160 & 150 & 140 & 130 & 120 & 110 & 100 & 90 & 80 & 70 & 60 & 50 & 40 & 30 & 20 & 10 & 0 & -:\end{array}$ 
${ }^{19} \mathrm{~F}$ NMR (376 MHz, $\mathrm{CDCl}_{3}$ )

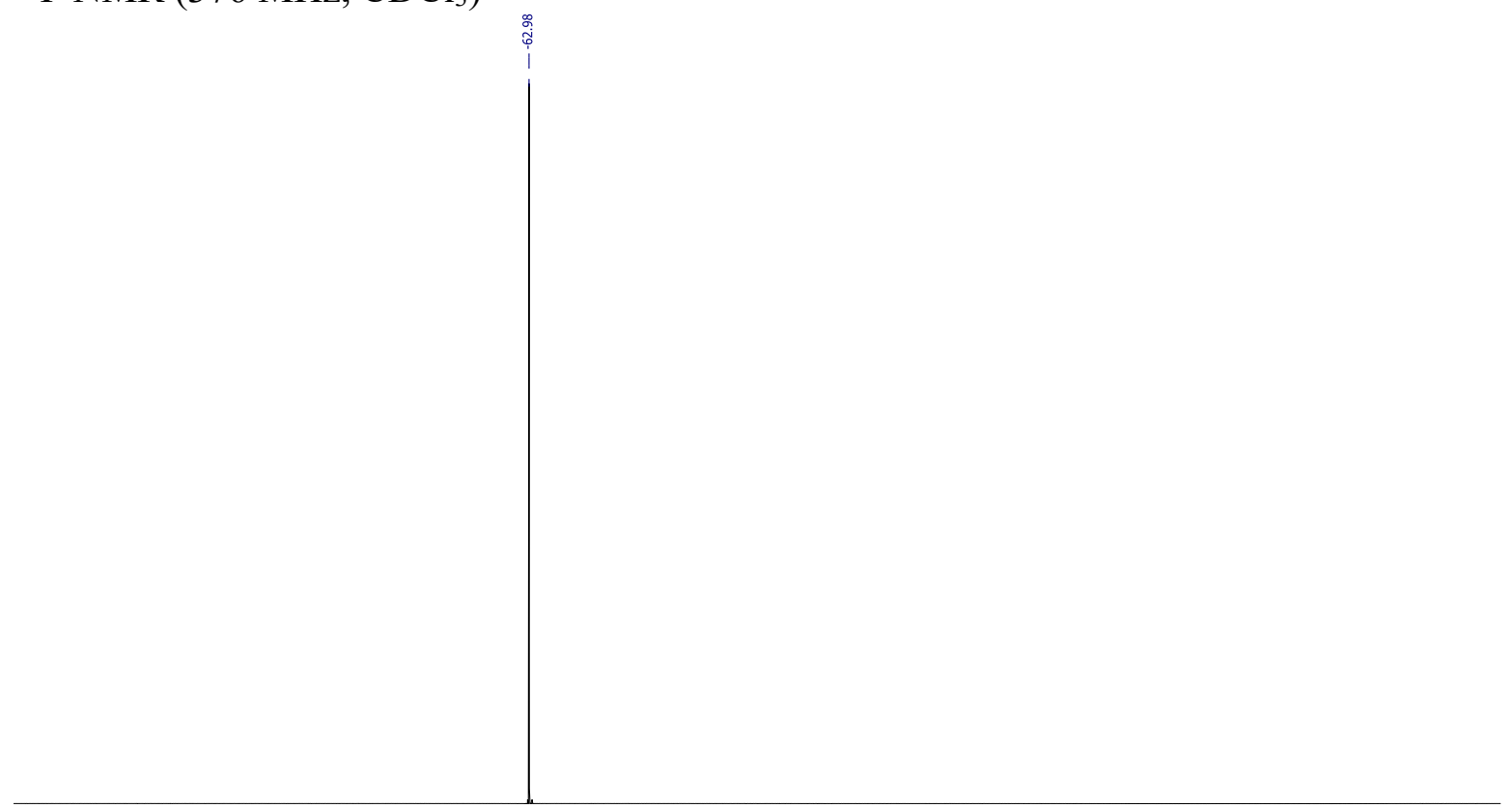

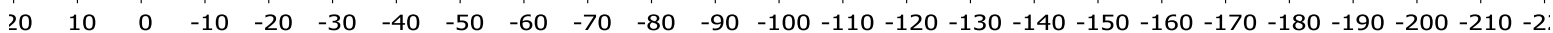




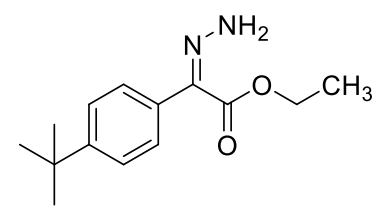

${ }^{1} \mathrm{H} \mathrm{NMR}\left(400 \mathrm{MHz}, \mathrm{CDCl}_{3}\right)$

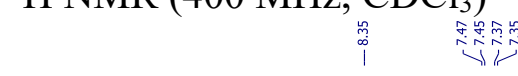

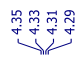
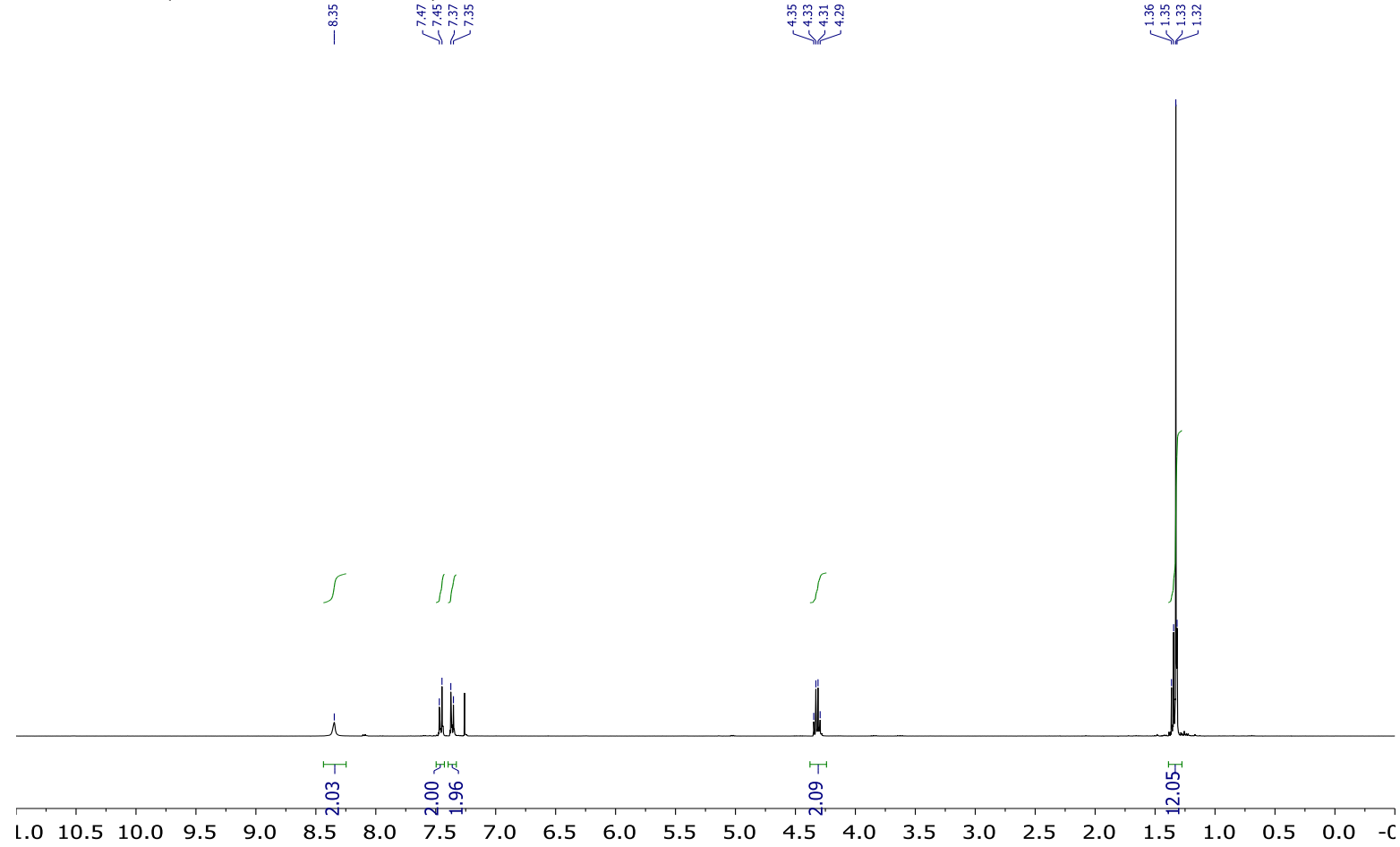

${ }^{13} \mathrm{C} \mathrm{NMR}\left(101 \mathrm{MHz}, \mathrm{CDCl}_{3}\right)$

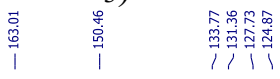

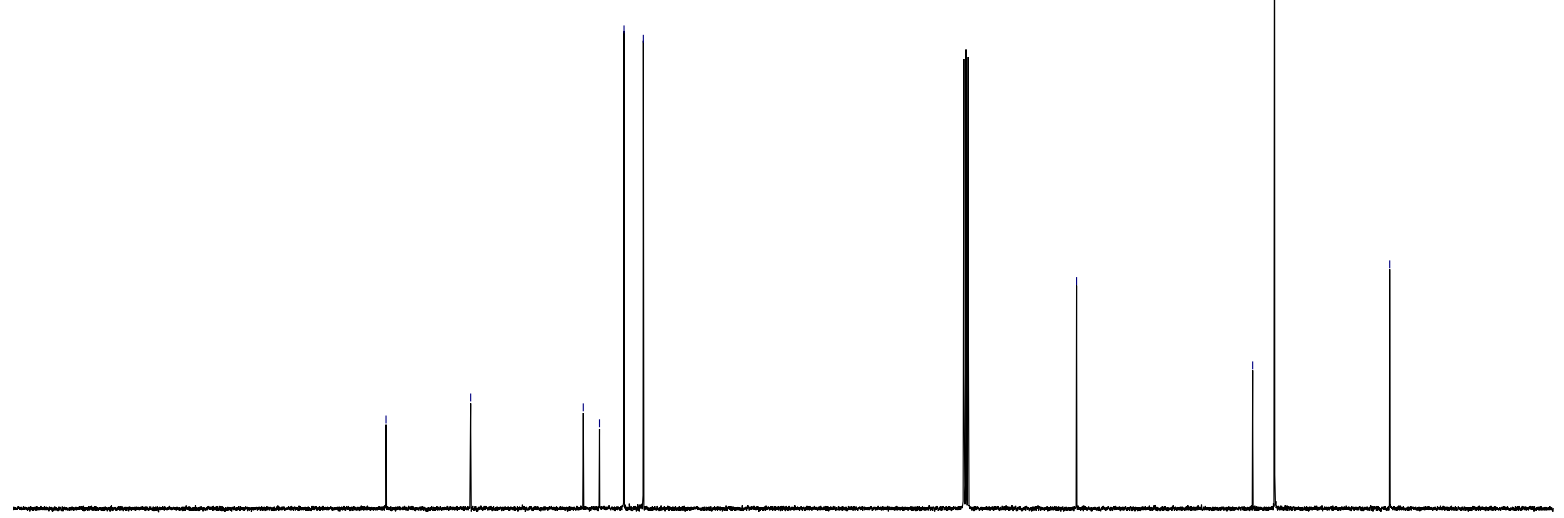

$\begin{array}{llllllllllll}210 & 200 & 190 & 180 & 170 & 160 & 150 & 140 & 130 & 120 & 110 & 100\end{array}$ $\circ$
0
0
1

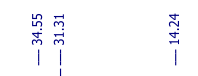




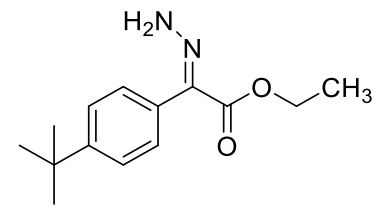

${ }^{1} \mathrm{H} \mathrm{NMR}\left(400 \mathrm{MHz}, \mathrm{CDCl}_{3}\right)$

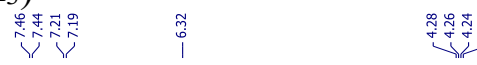

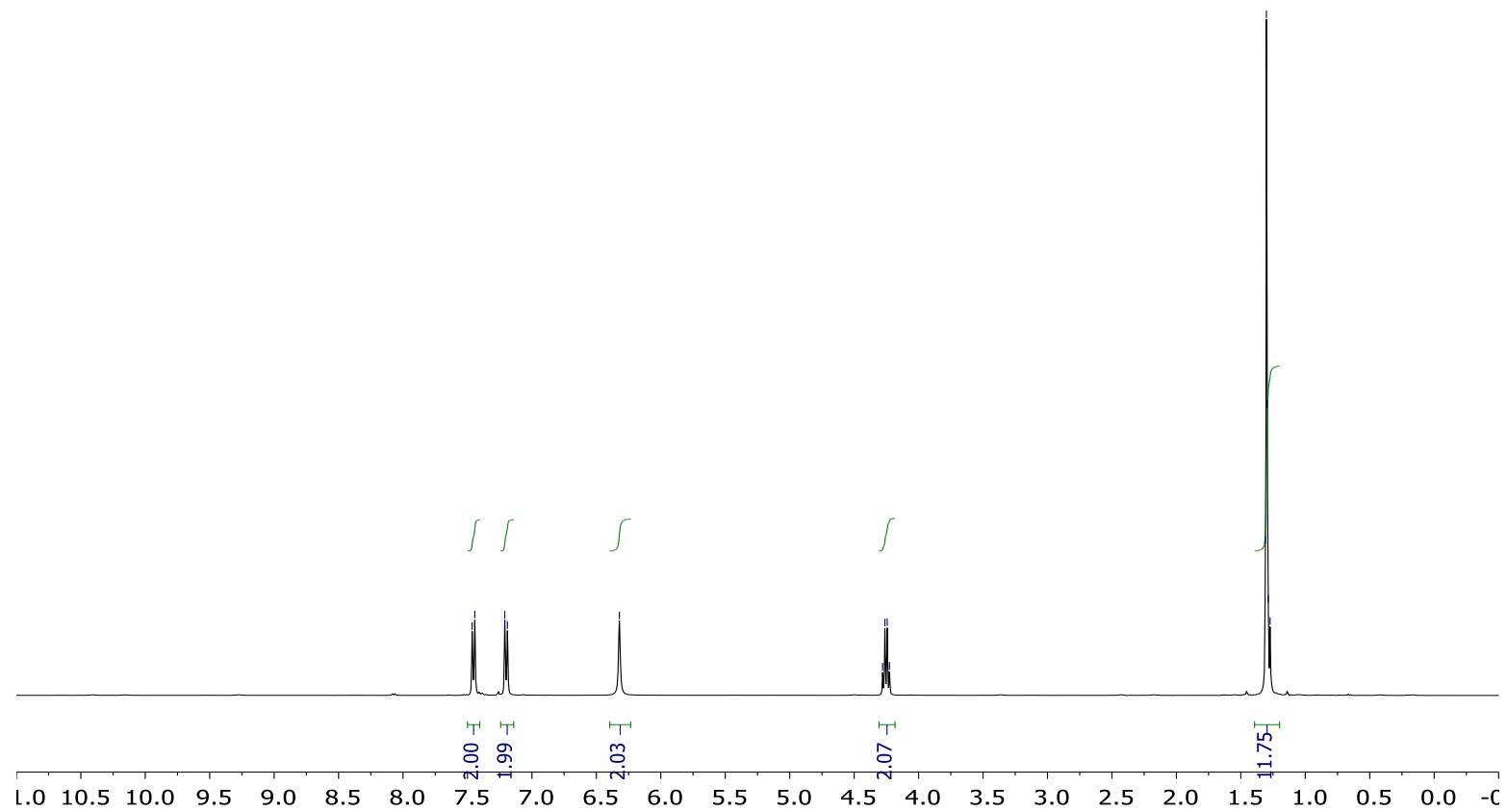

$\left.{ }^{13} \mathrm{C} \mathrm{NMR} \mathrm{(101} \mathrm{MHz,} \mathrm{CDCl}_{3}\right)$

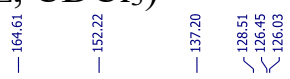

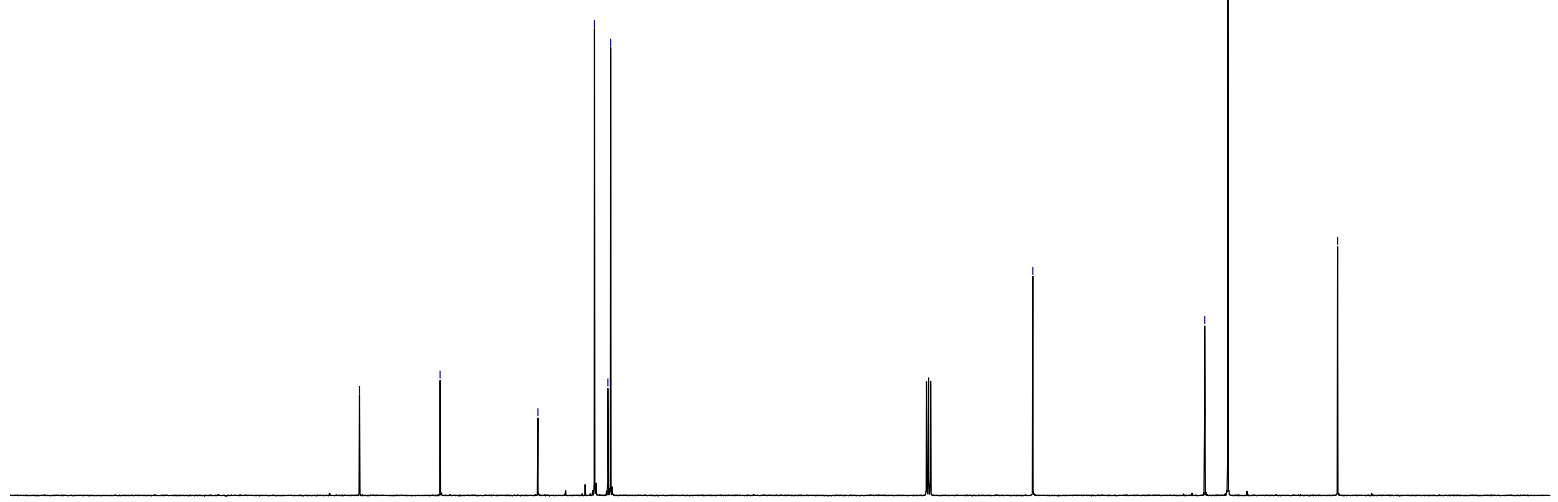

$\begin{array}{lllllllllllllllllllllll}210 & 200 & 190 & 180 & 170 & 160 & 150 & 140 & 130 & 120 & 110 & 100 & 90 & 80 & 70 & 60 & 50 & 40 & 30 & 20 & 10 & 0 & -10\end{array}$ 
<smiles>CCOC(=O)C(=NN)c1ccc(Cl)nc1</smiles>

${ }^{1} \mathrm{H} \mathrm{NMR}\left(600 \mathrm{MHz}, \mathrm{CDCl}_{3}\right)$
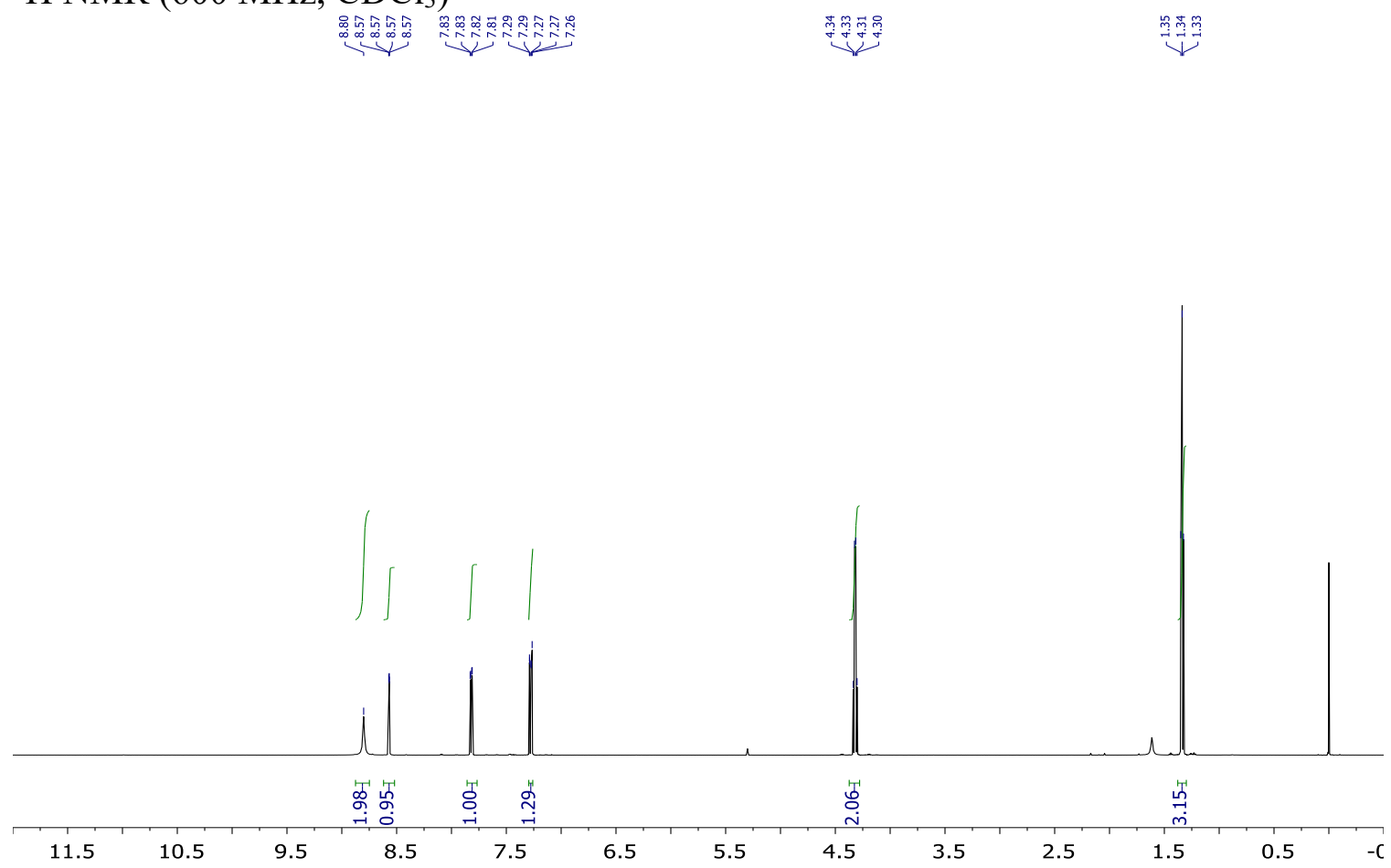

${ }^{13} \mathrm{C} \mathrm{NMR}\left(151 \mathrm{MHz}, \mathrm{CDCl}_{3}\right)$

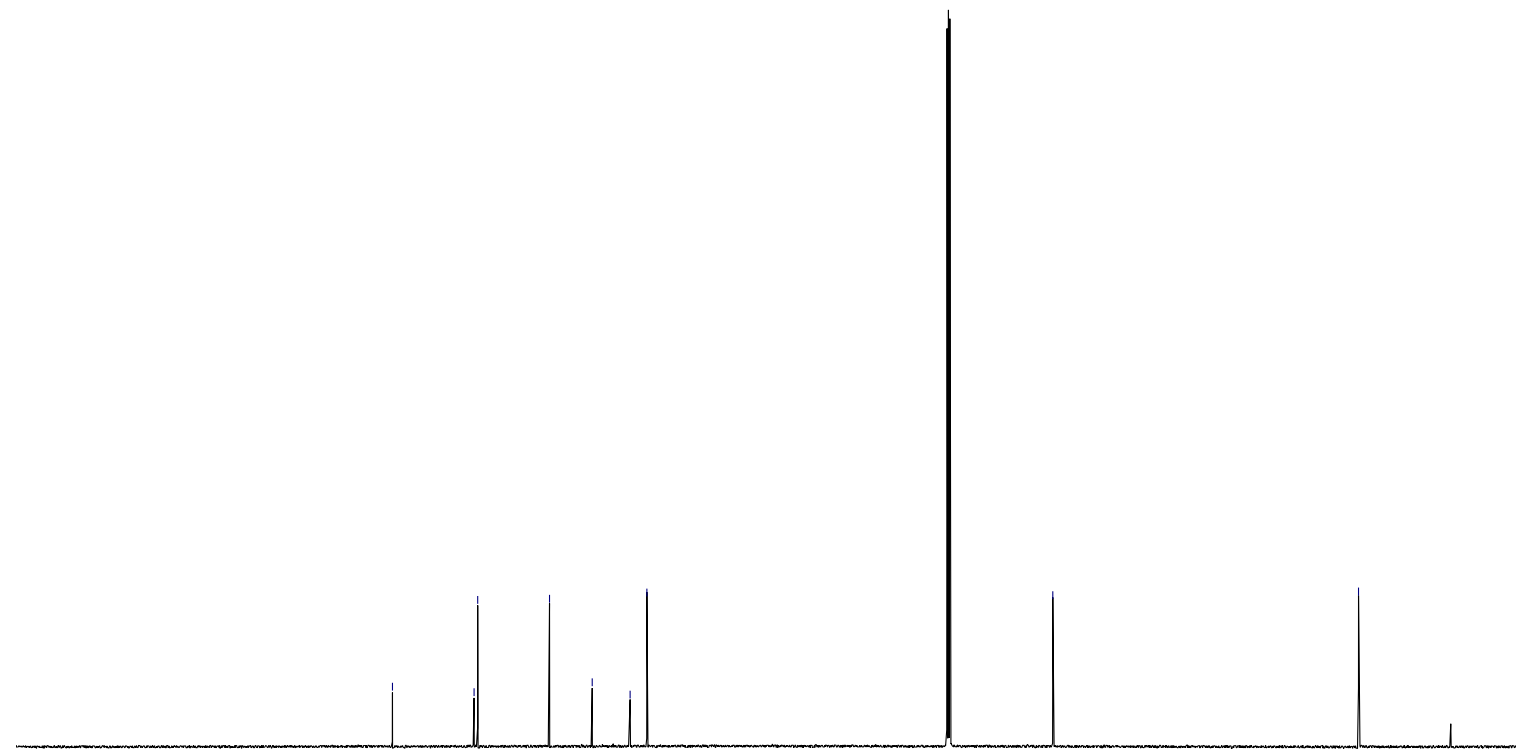

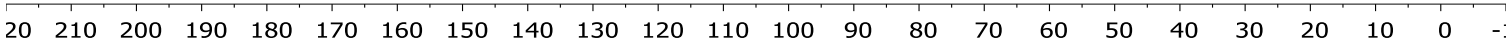


<smiles>CCOC(=O)C(=NN)c1ccc(Cl)nc1</smiles>

${ }^{1} \mathrm{H} \mathrm{NMR}\left(600 \mathrm{MHz}, \mathrm{CDCl}_{3}\right)$

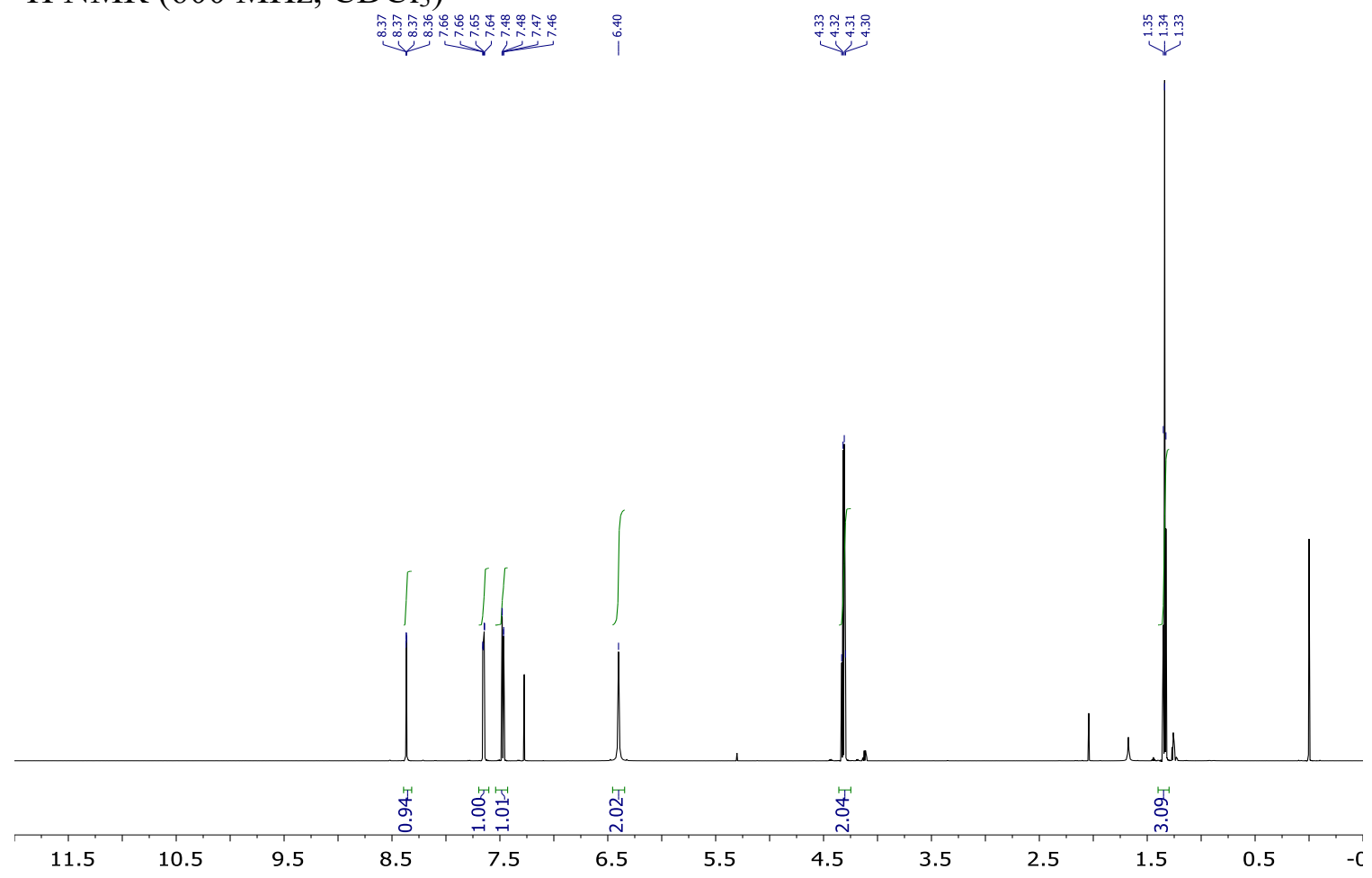

${ }^{13} \mathrm{C}$ NMR $\left(151 \mathrm{MHz}, \mathrm{CDCl}_{3}\right)$

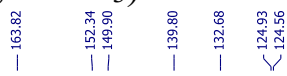
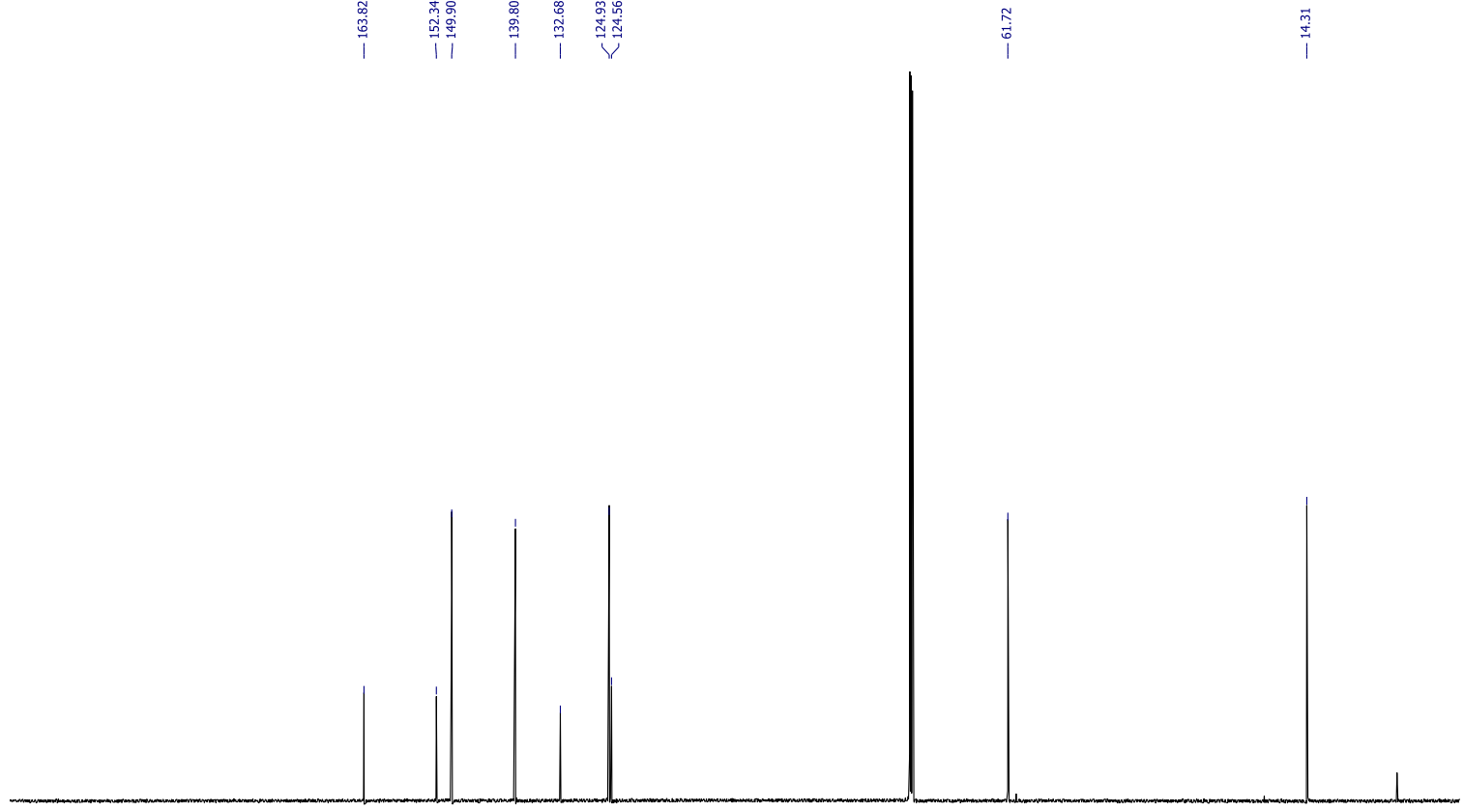

\begin{tabular}{lllllllllllllllllllllllll}
\hline 20 & 210 & 200 & 190 & 180 & 170 & 160 & 150 & 140 & 130 & 120 & 110 & 100 & 90 & 80 & 70 & 60 & 50 & 40 & 30 & 20 & 10 & 0 & $-:$
\end{tabular} 
<smiles>N=C(C(=O)OCC(Cl)(Cl)Cl)c1ccc(Br)cc1</smiles>

${ }^{1} \mathrm{H} \mathrm{NMR}\left(600 \mathrm{MHz}, \mathrm{CDCl}_{3}\right)$

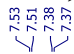

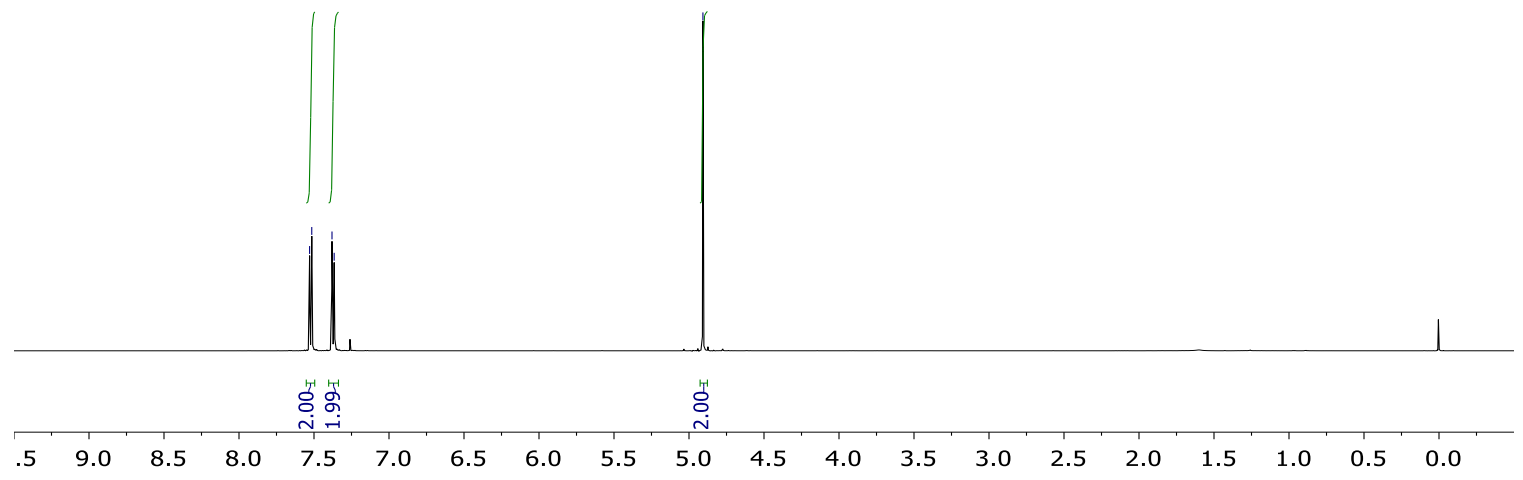

${ }^{13} \mathrm{C}$ NMR (151 MHz, $\left.\mathrm{CDCl}_{3}\right)$

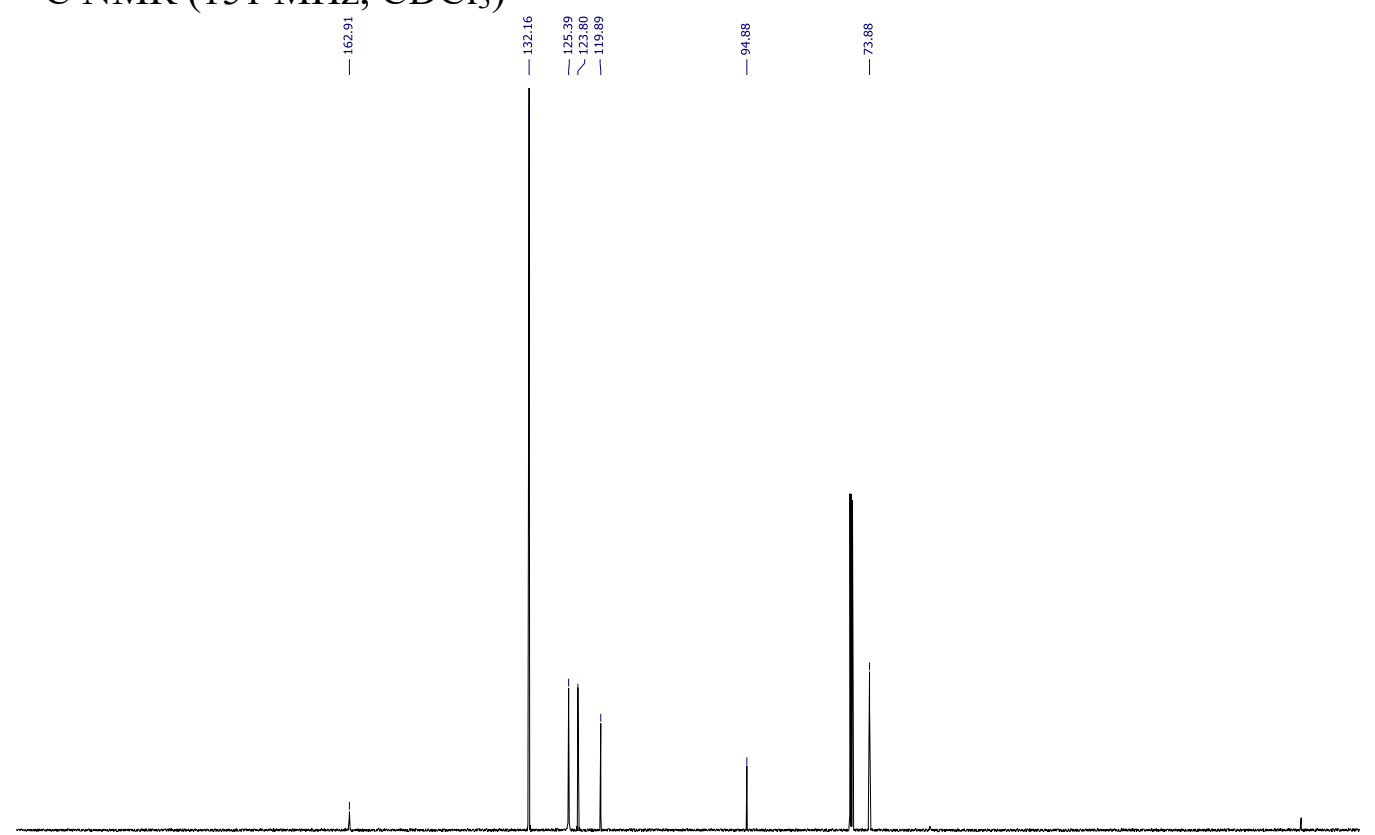

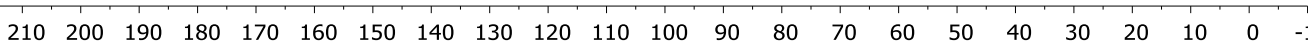


<smiles>CC(C)(C)COC(=O)C(=N)c1ccc(Br)cc1</smiles>

${ }^{1} \mathrm{H}$ NMR (600 MHz, $\mathrm{CDCl}_{3}$ )

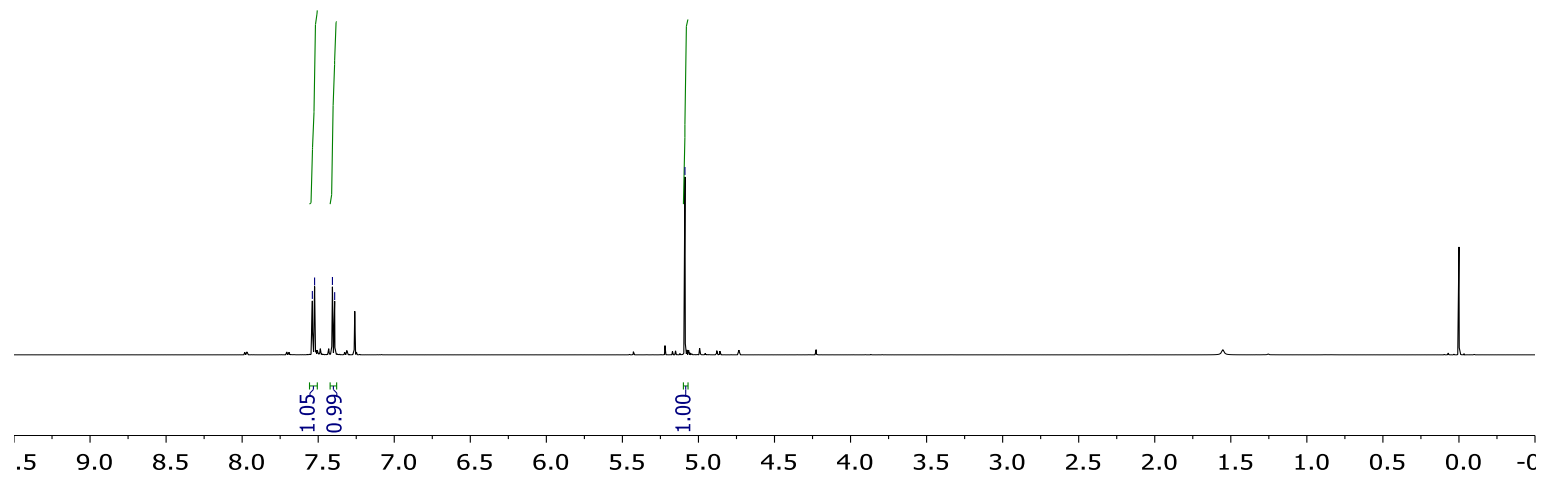

${ }^{13} \mathrm{C} \mathrm{NMR}\left(151 \mathrm{MHz}, \mathrm{CDCl}_{3}\right)$
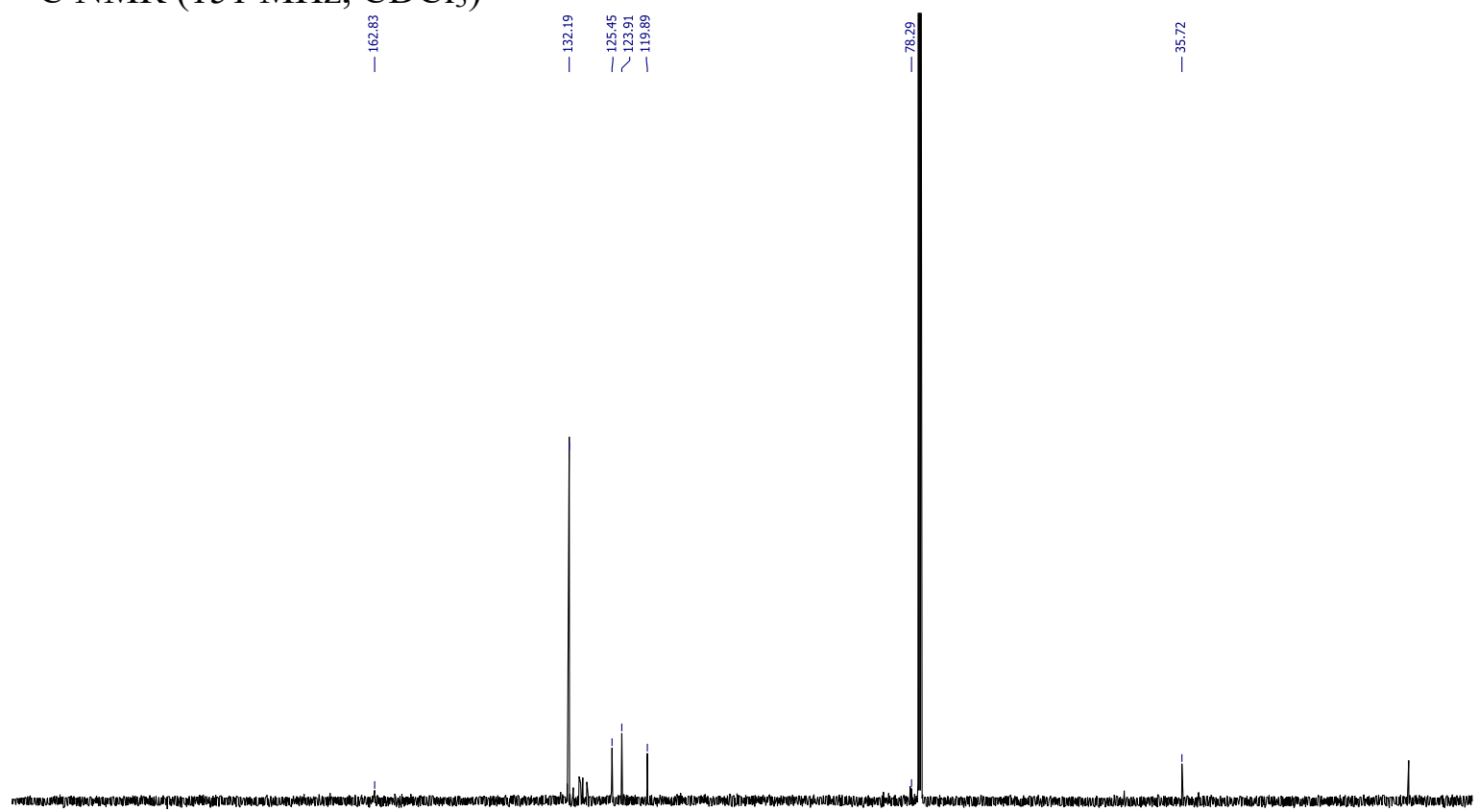

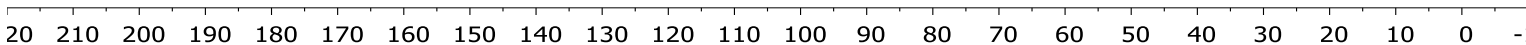


<smiles>N=C(C(=O)OCC(F)(F)F)c1ccc(Br)cc1</smiles>

${ }^{1} \mathrm{H} \mathrm{NMR}\left(600 \mathrm{MHz}, \mathrm{CDCl}_{3}\right)$

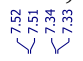
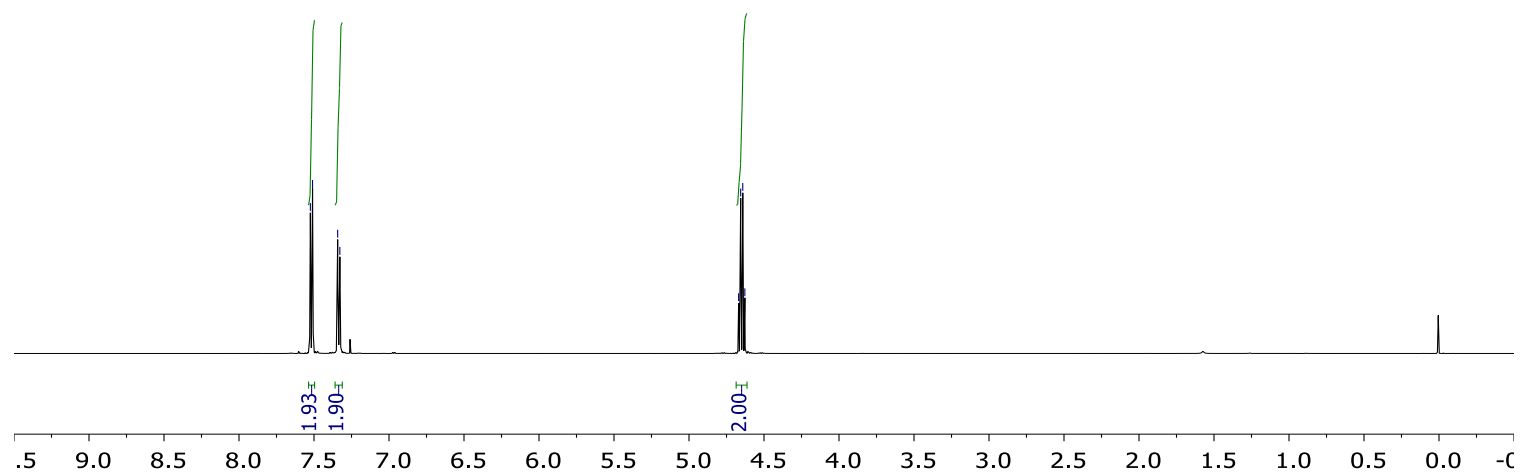
${ }^{13} \mathrm{C} \mathrm{NMR}\left(151 \mathrm{MHz}, \mathrm{CDCl}_{3}\right.$ )
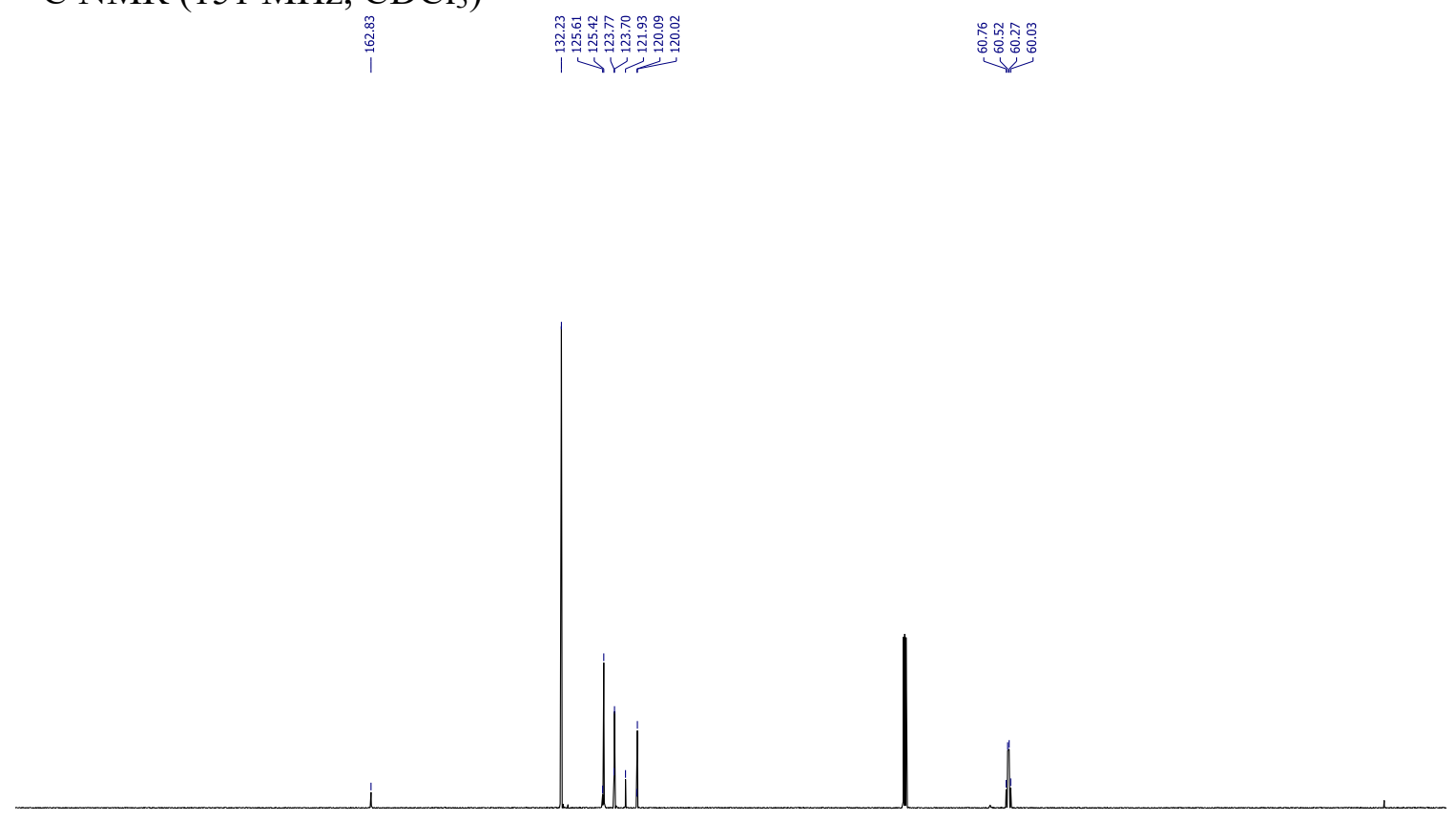

$\begin{array}{lllllllllllllllllllllllll}20 & 210 & 200 & 190 & 180 & 170 & 160 & 150 & 140 & 130 & 120 & 110 & 100 & 90 & 80 & 70 & 60 & 50 & 40 & 30 & 20 & 10 & 0 & -:\end{array}$ 
<smiles>CCOC(=O)C(=N)c1ccc(Br)cc1</smiles>

${ }^{1} \mathrm{H}$ NMR $\left(600 \mathrm{MHz}, \mathrm{CDCl}_{3}\right.$ )

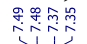

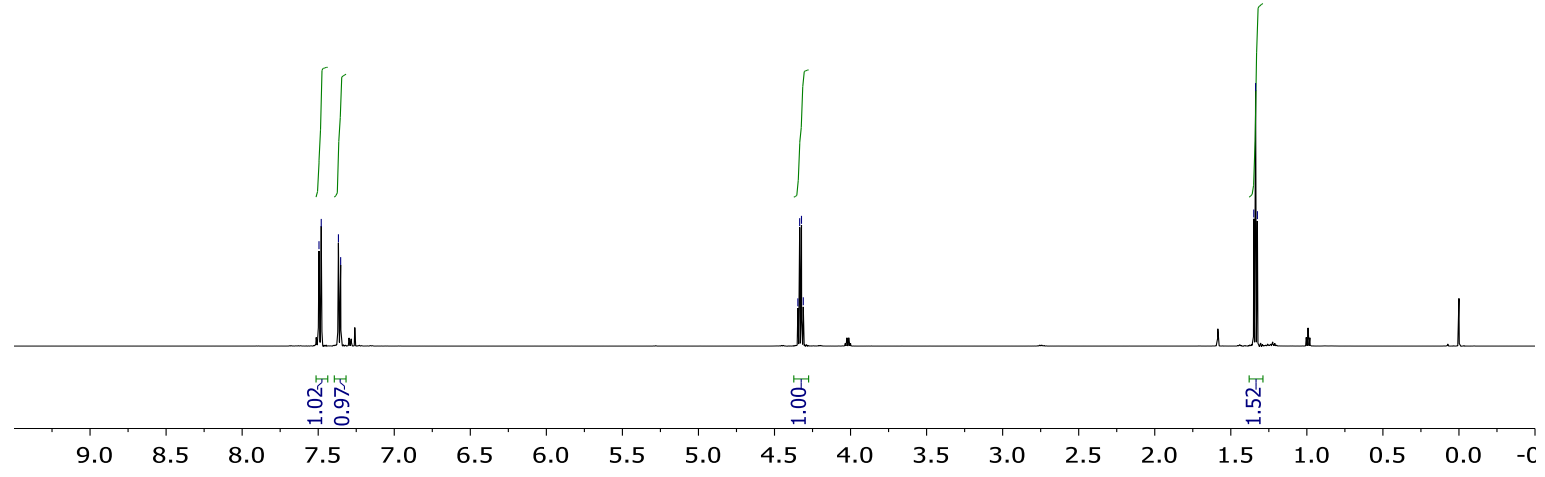

${ }^{13} \mathrm{C} \mathrm{NMR}\left(151 \mathrm{MHz}, \mathrm{CDCl}_{3}\right)$

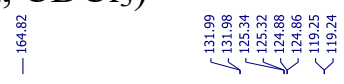

Үิํํำ

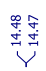

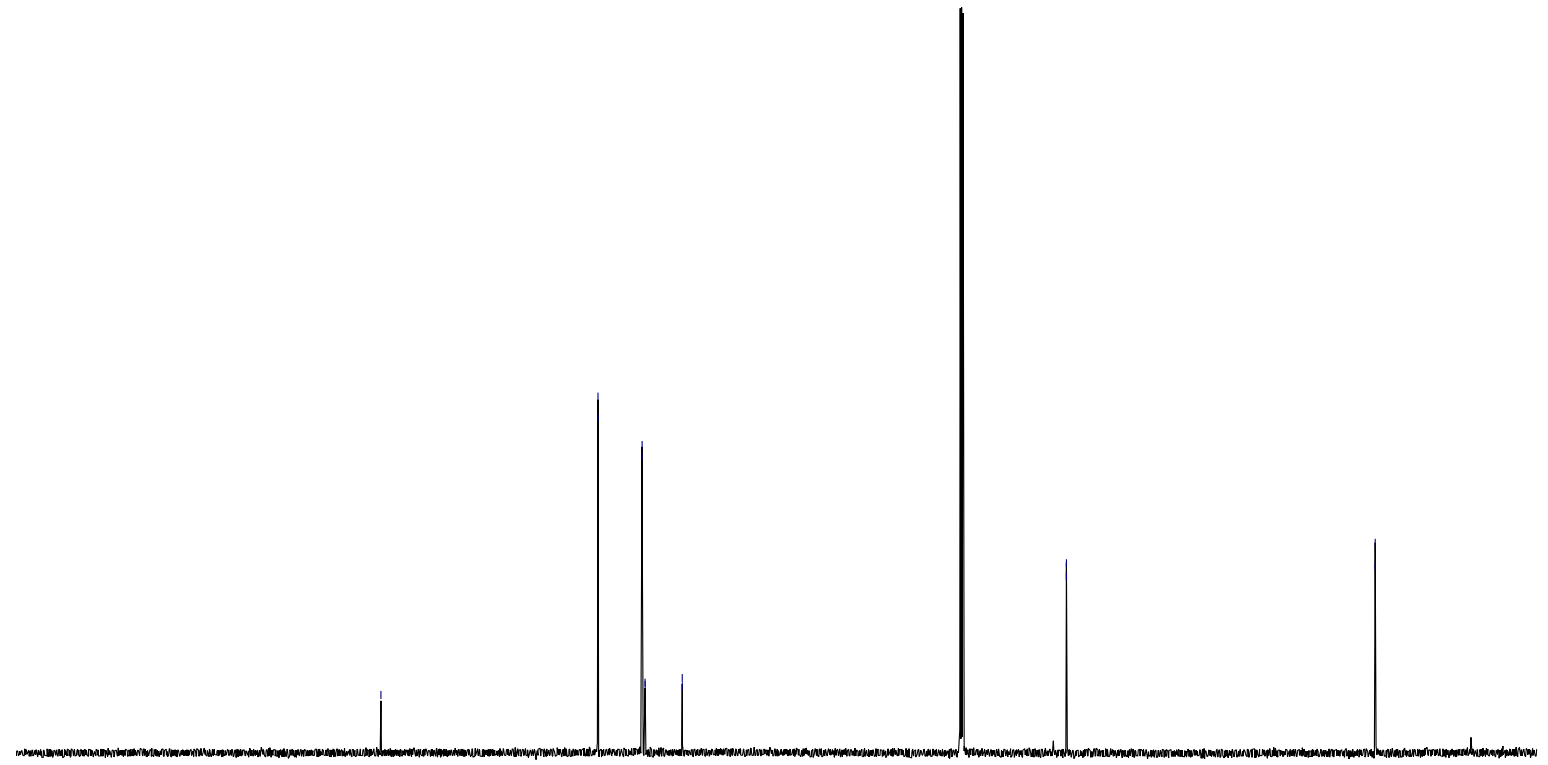

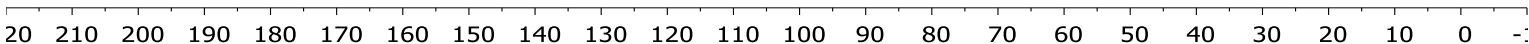


<smiles>N#CC(=O)OCC(Cl)(Cl)Cl</smiles>

${ }^{1} \mathrm{H}$ NMR $\left(600 \mathrm{MHz}, \mathrm{CDCl}_{3}\right)$

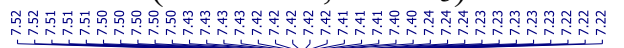
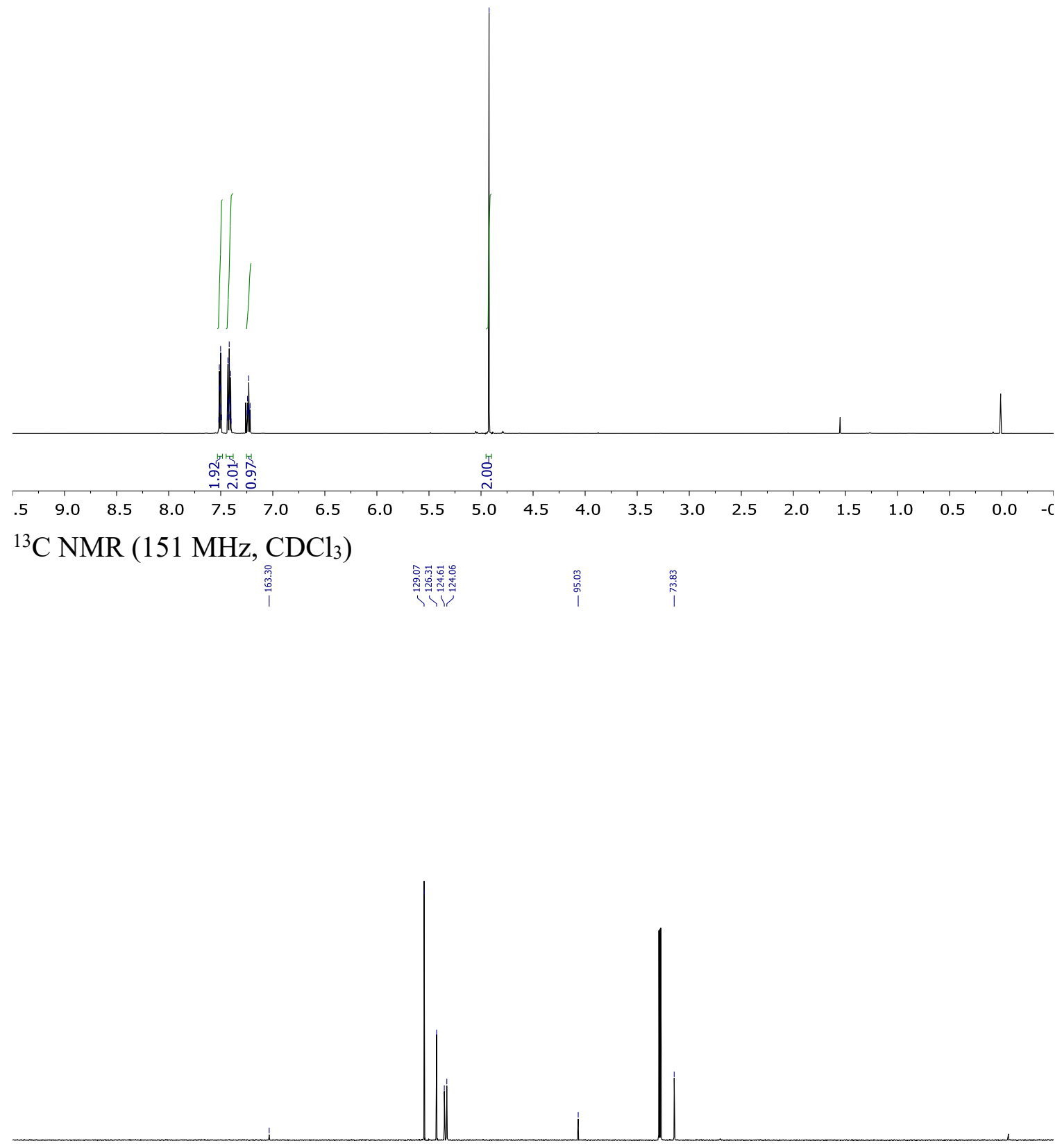

$\begin{array}{lllllllllllllllllllllll}210 & 200 & 190 & 180 & 170 & 160 & 150 & 140 & 130 & 120 & 110 & 100 & 90 & 80 & 70 & 60 & 50 & 40 & 30 & 20 & 10 & 0 & -:\end{array}$ 


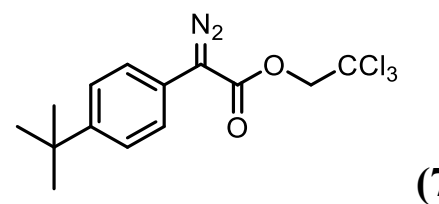

${ }^{1} \mathrm{H} \mathrm{NMR}\left(600 \mathrm{MHz}, \mathrm{CDCl}_{3}\right)$

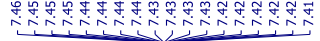

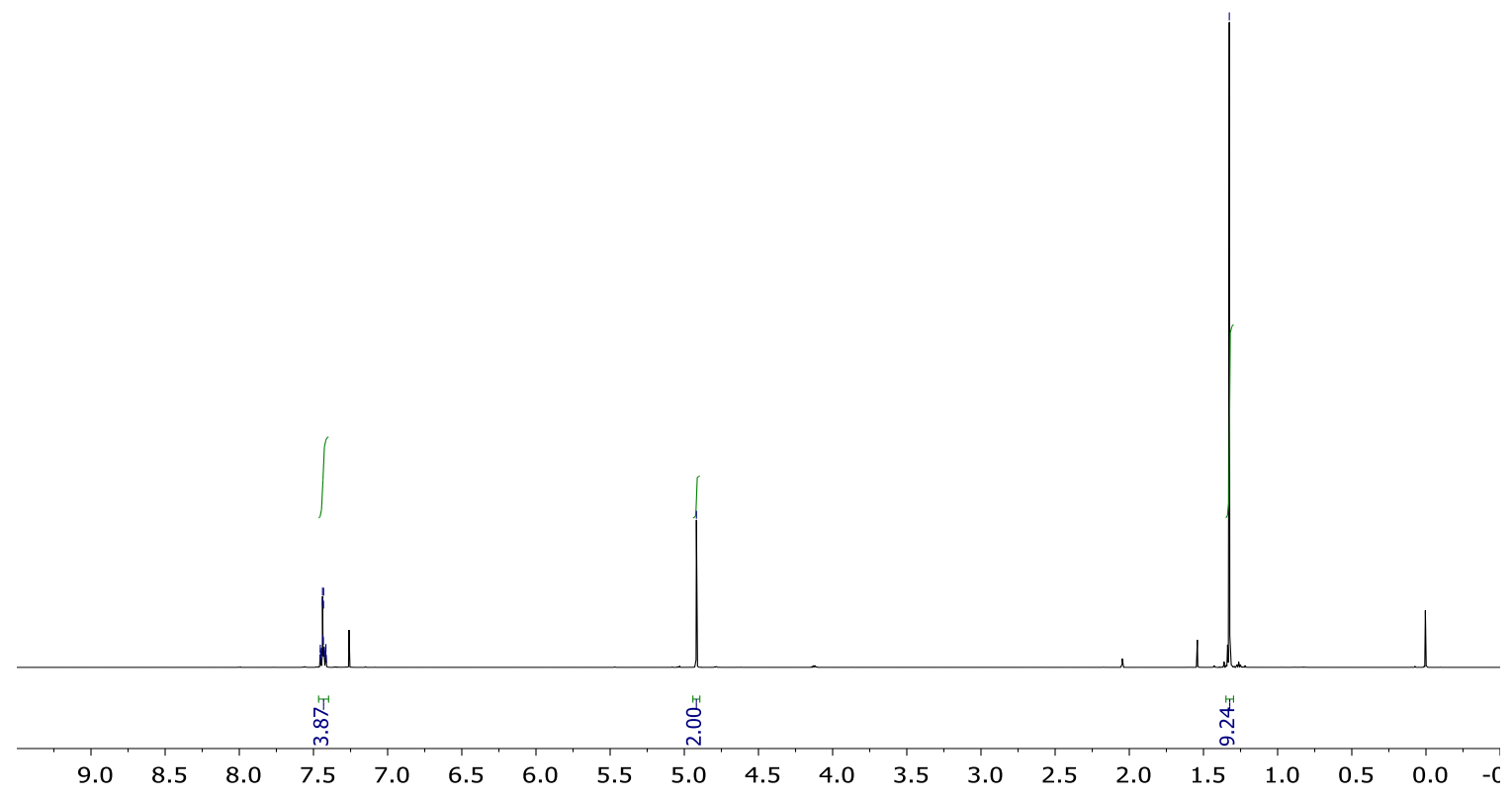
${ }^{13} \mathrm{C}$ NMR (151 MHz, $\left.\mathrm{CDCl}_{3}\right)$

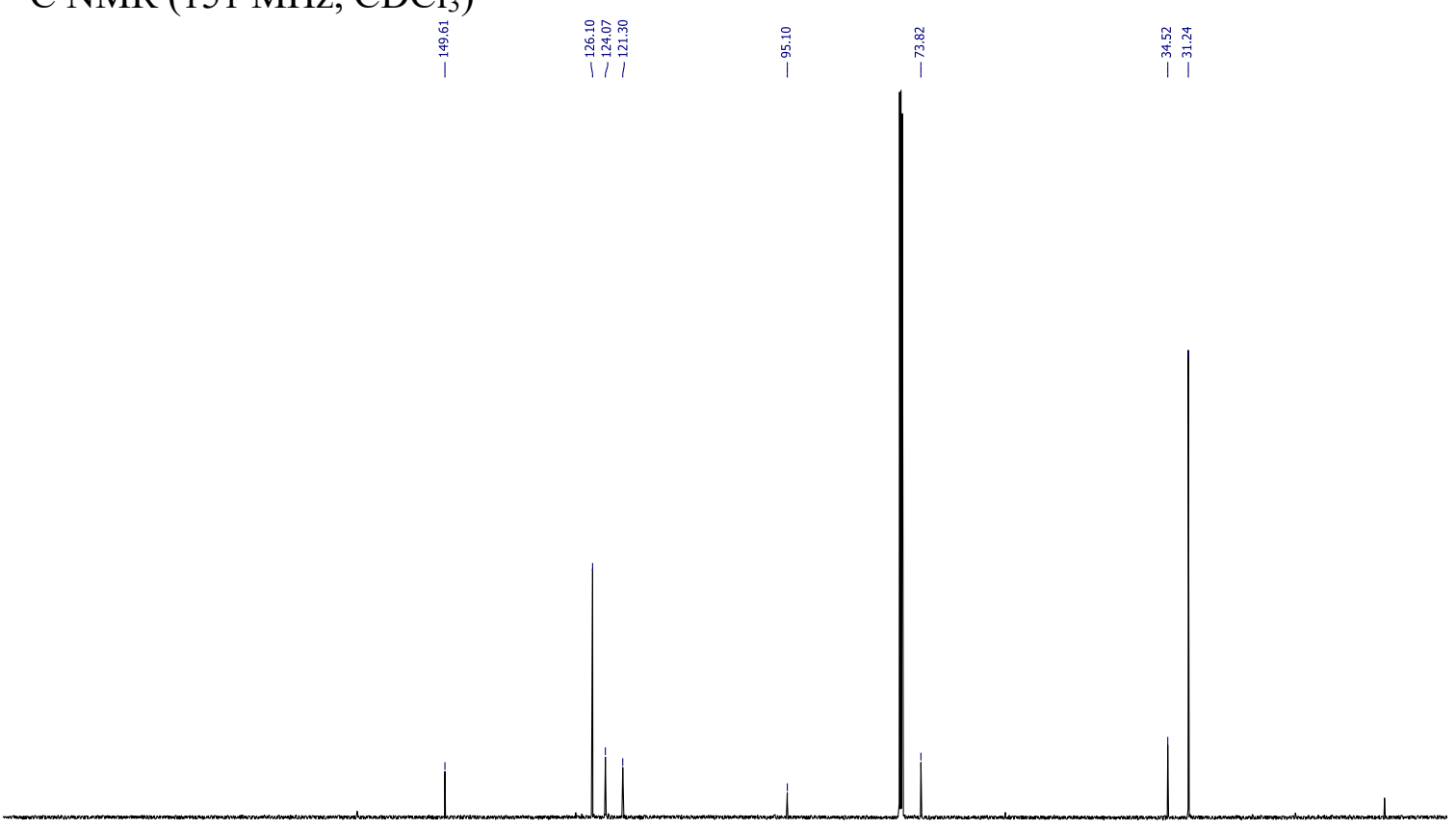

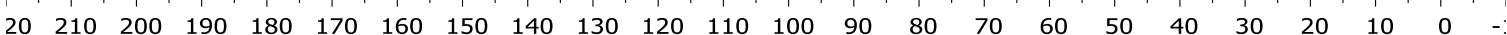


$\overbrace{0}^{N_{2}} \sim^{\mathrm{CCl}_{3}}$

${ }^{1} \mathrm{H}$ NMR (600 MHz, $\mathrm{CDCl}_{3}$ )

毒员

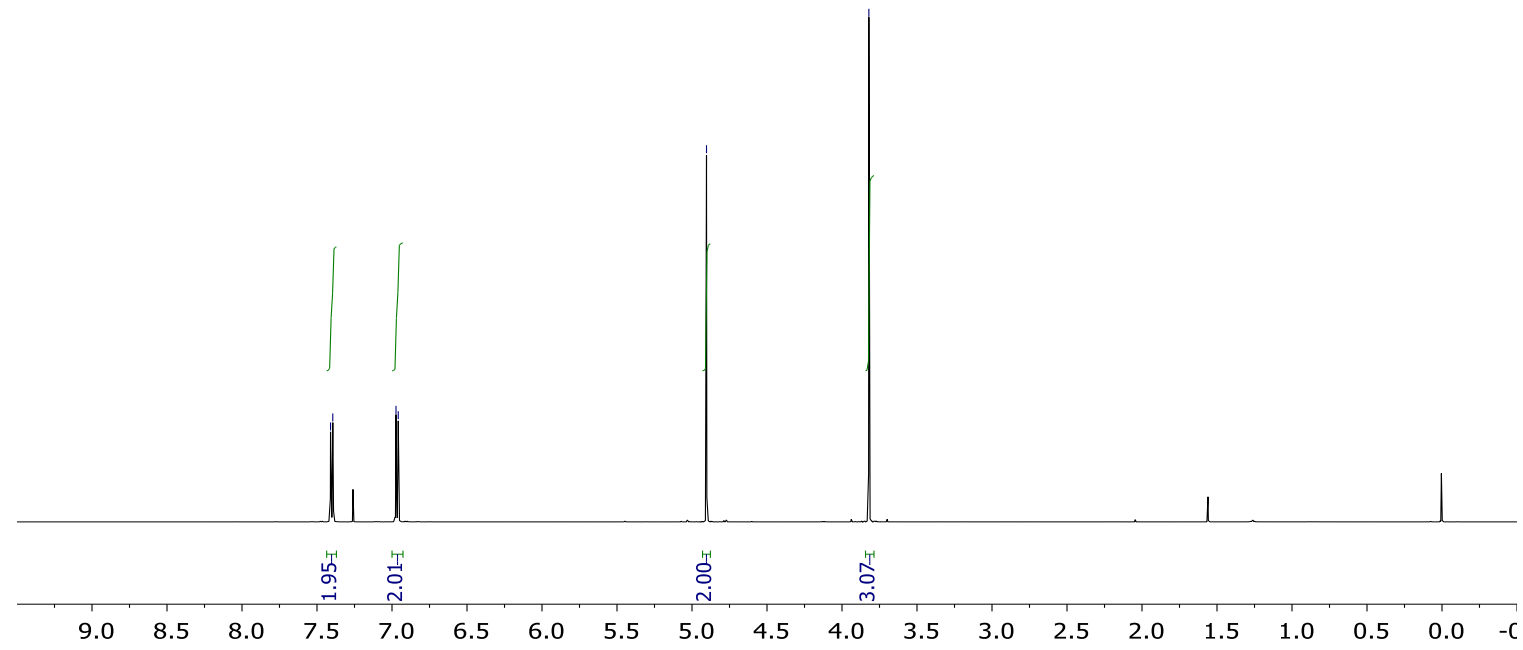

${ }^{13} \mathrm{C} \mathrm{NMR}\left(151 \mathrm{MHz}, \mathrm{CDCl}_{3}\right)$

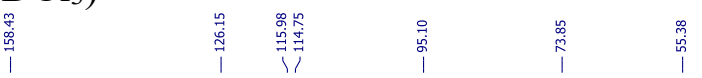

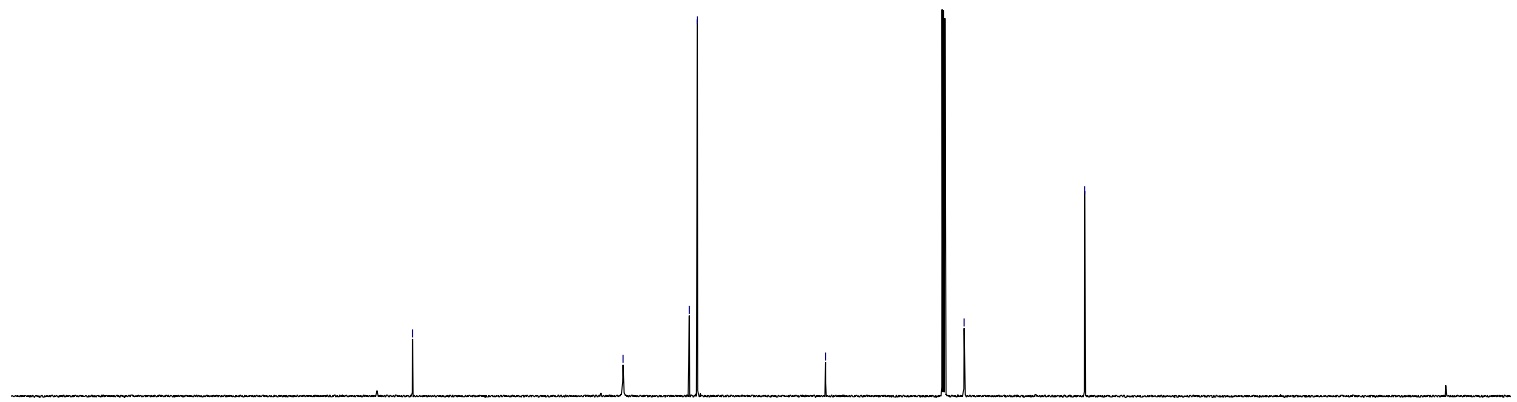

$20 \begin{array}{llllllllllllllllllllllllllll} & 210 & 200 & 190 & 180 & 170 & 160 & 150 & 140 & 130 & 120 & 110 & 100 & 90 & 80 & 70 & 60 & 50 & 40 & 30 & 20 & 10 & 0 & -:\end{array}$ 
(9)

${ }^{1} \mathrm{H}$ NMR (400 MHz, $\mathrm{CDCl}_{3}$ )

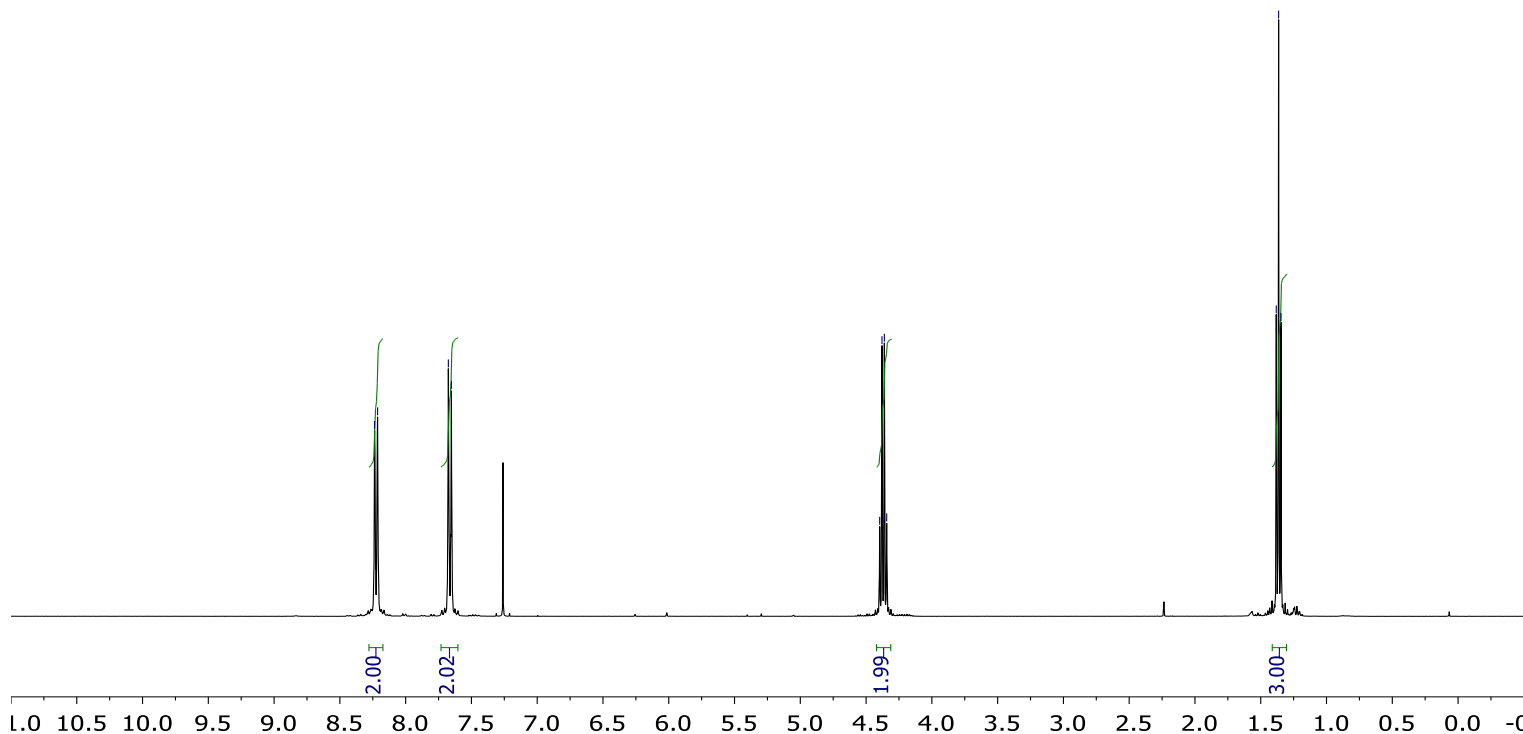

${ }^{13} \mathrm{C} \mathrm{NMR}\left(101 \mathrm{MHz}, \mathrm{CDCl}_{3}\right)$

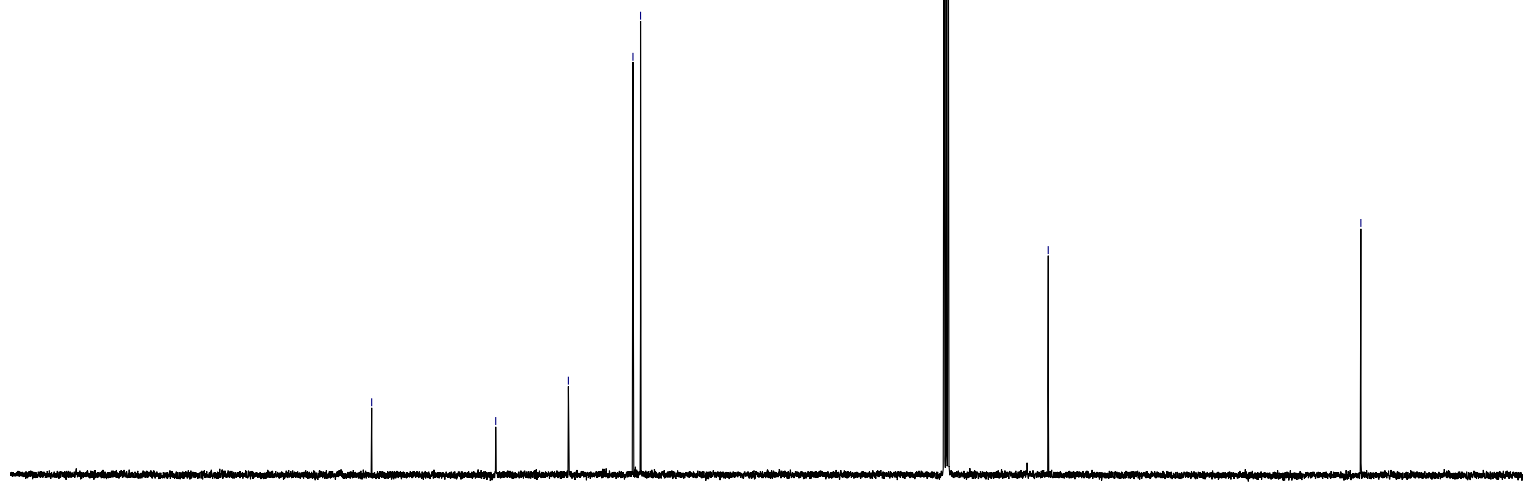

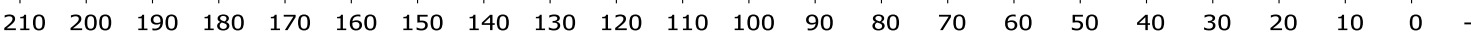


<smiles>CCOC(=O)C(=N)c1ccc(F)cc1</smiles>

${ }^{1} \mathrm{H}$ NMR $\left(400 \mathrm{MHz}, \mathrm{CDCl}_{3}\right)$

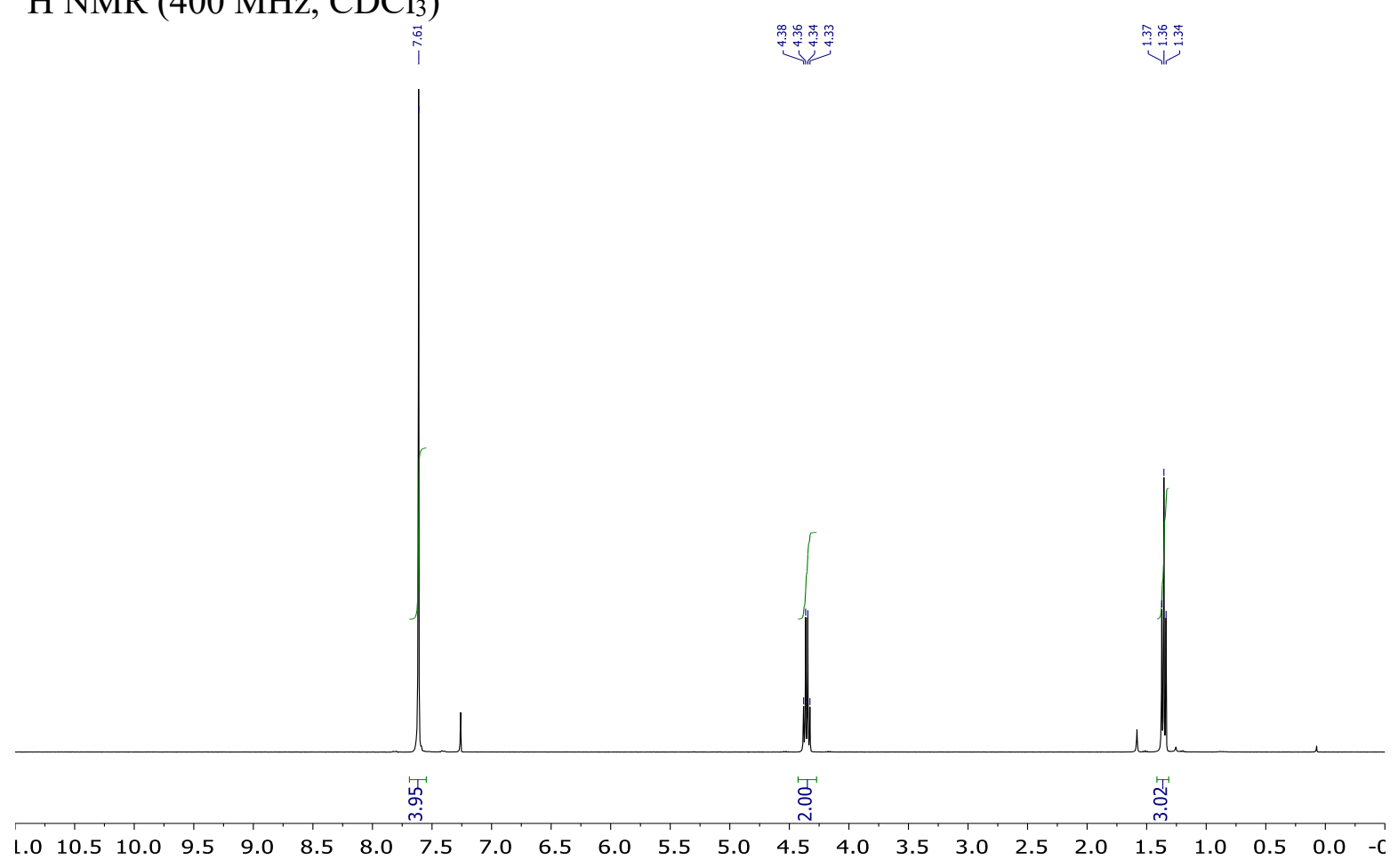

${ }^{13} \mathrm{C} \mathrm{NMR}\left(101 \mathrm{MHz}, \mathrm{CDCl}_{3}\right)$
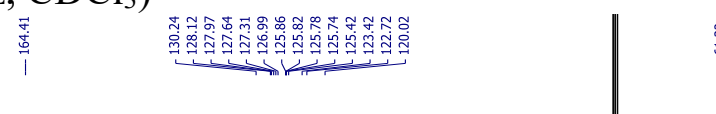

$\stackrel{1}{10}$

$\begin{array}{lllllllllllllllllllllll}210 & 200 & 190 & 180 & 170 & 160 & 150 & 140 & 130 & 120 & 110 & 100 & 90 & 80 & 70 & 60 & 50 & 40 & 30 & 20 & 10 & 0 & -\end{array}$ 
${ }^{19} \mathrm{~F}$ NMR $\left(376 \mathrm{MHz}, \mathrm{CDCl}_{3}\right)$

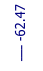

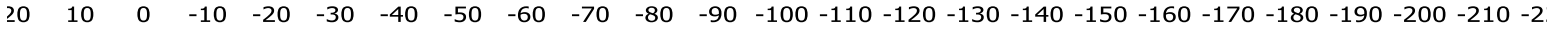


<smiles>CCOC(=O)C(=N)c1ccccc1</smiles>

(11)

${ }^{1} \mathrm{H} \mathrm{NMR}\left(400 \mathrm{MHz}, \mathrm{CDCl}_{3}\right)$

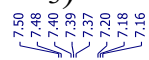

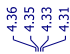

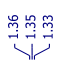

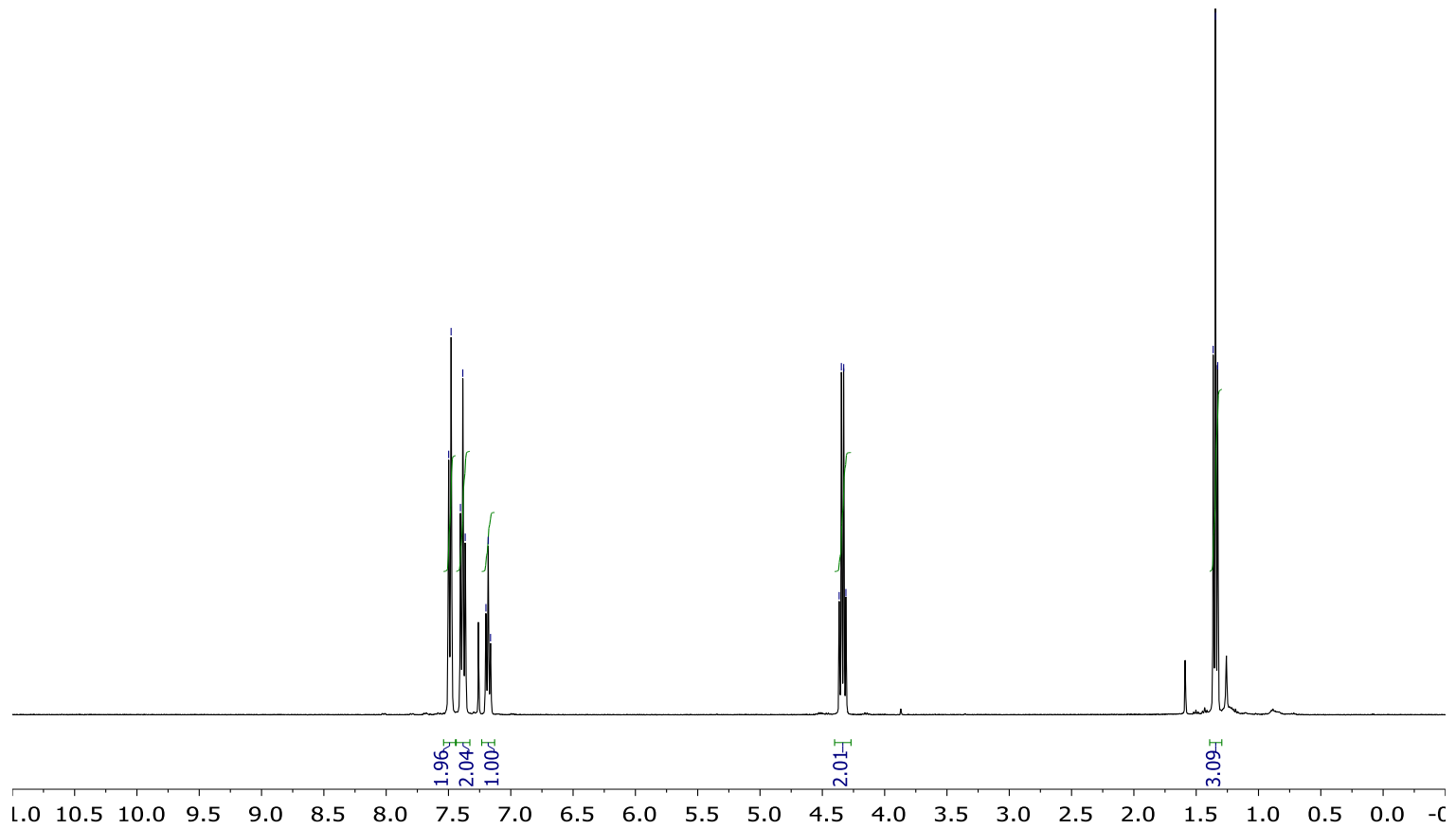

${ }^{13} \mathrm{C}$ NMR (101 MHz, $\left.\mathrm{CDCl}_{3}\right)$

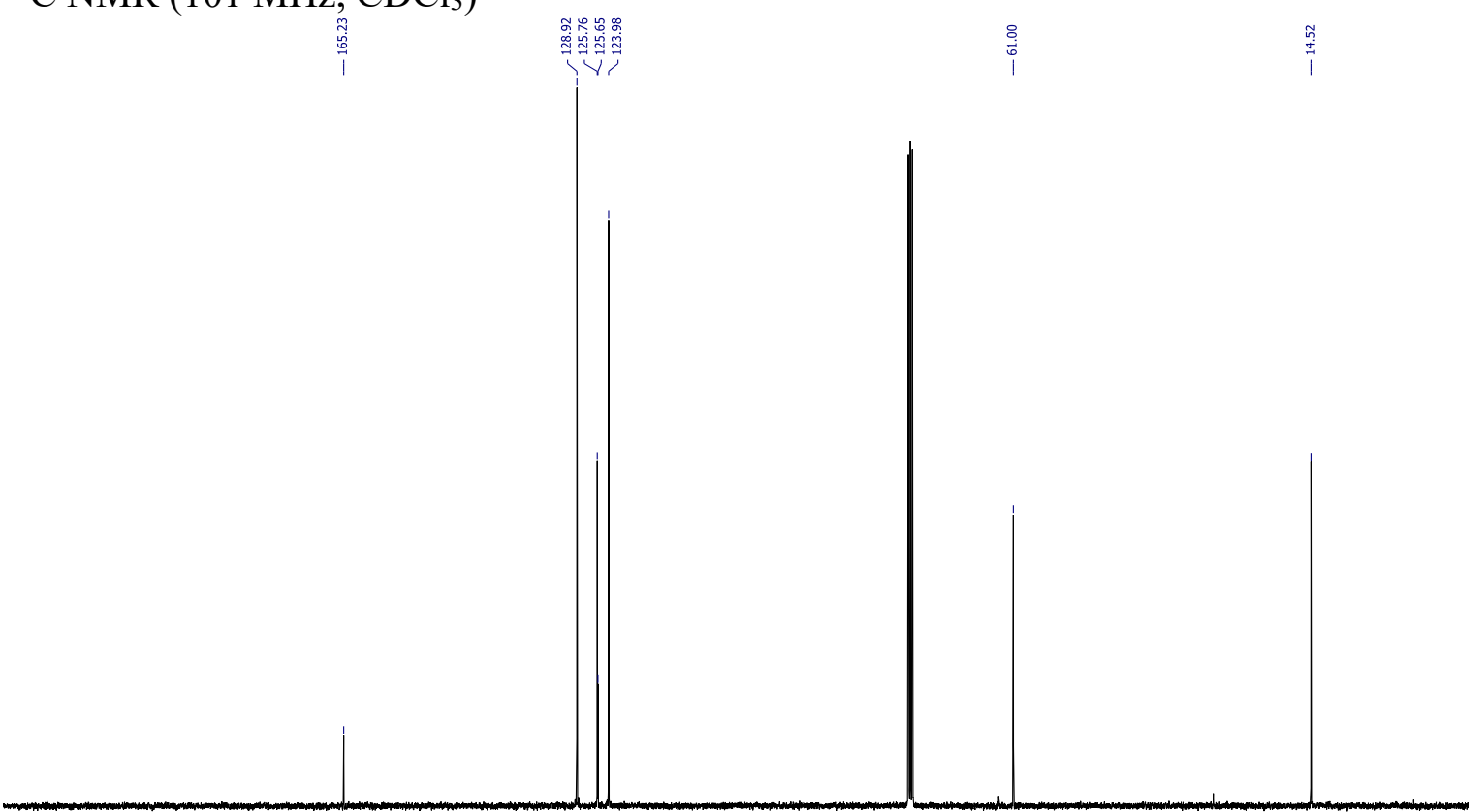

$\begin{array}{lllllllllllllllllllllll}210 & 200 & 190 & 180 & 170 & 160 & 150 & 140 & 130 & 120 & 110 & 100 & 90 & 80 & 70 & 60 & 50 & 40 & 30 & 20 & 10 & 0 & -:\end{array}$ 


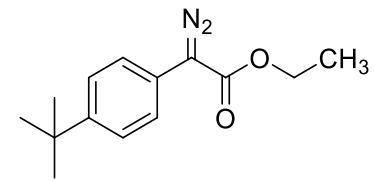

${ }^{1} \mathrm{H} \mathrm{NMR}\left(400 \mathrm{MHz}, \mathrm{CDCl}_{3}\right)$

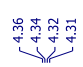
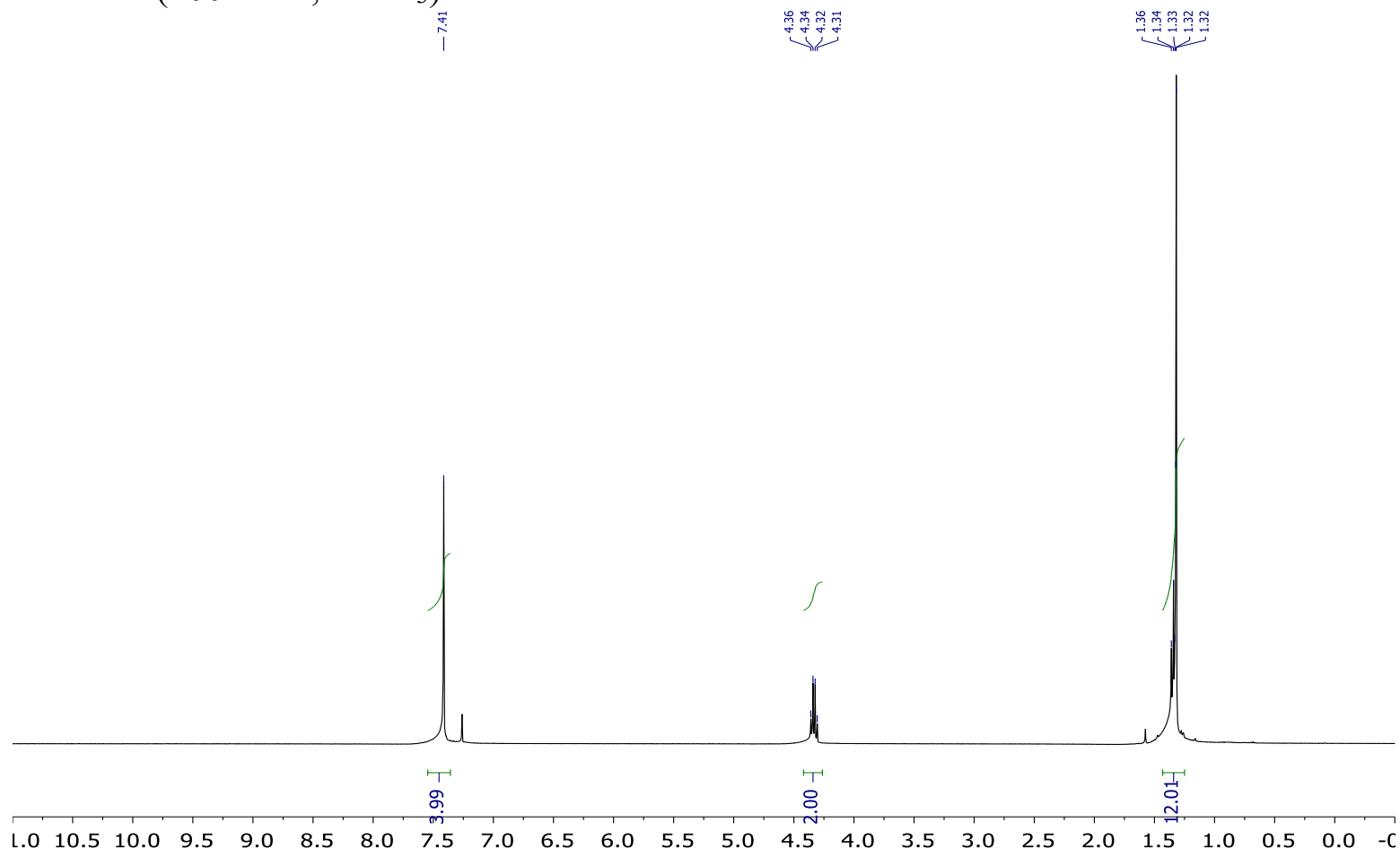

${ }^{13} \mathrm{C}$ NMR (101 MHz, $\left.\mathrm{CDCl}_{3}\right)$
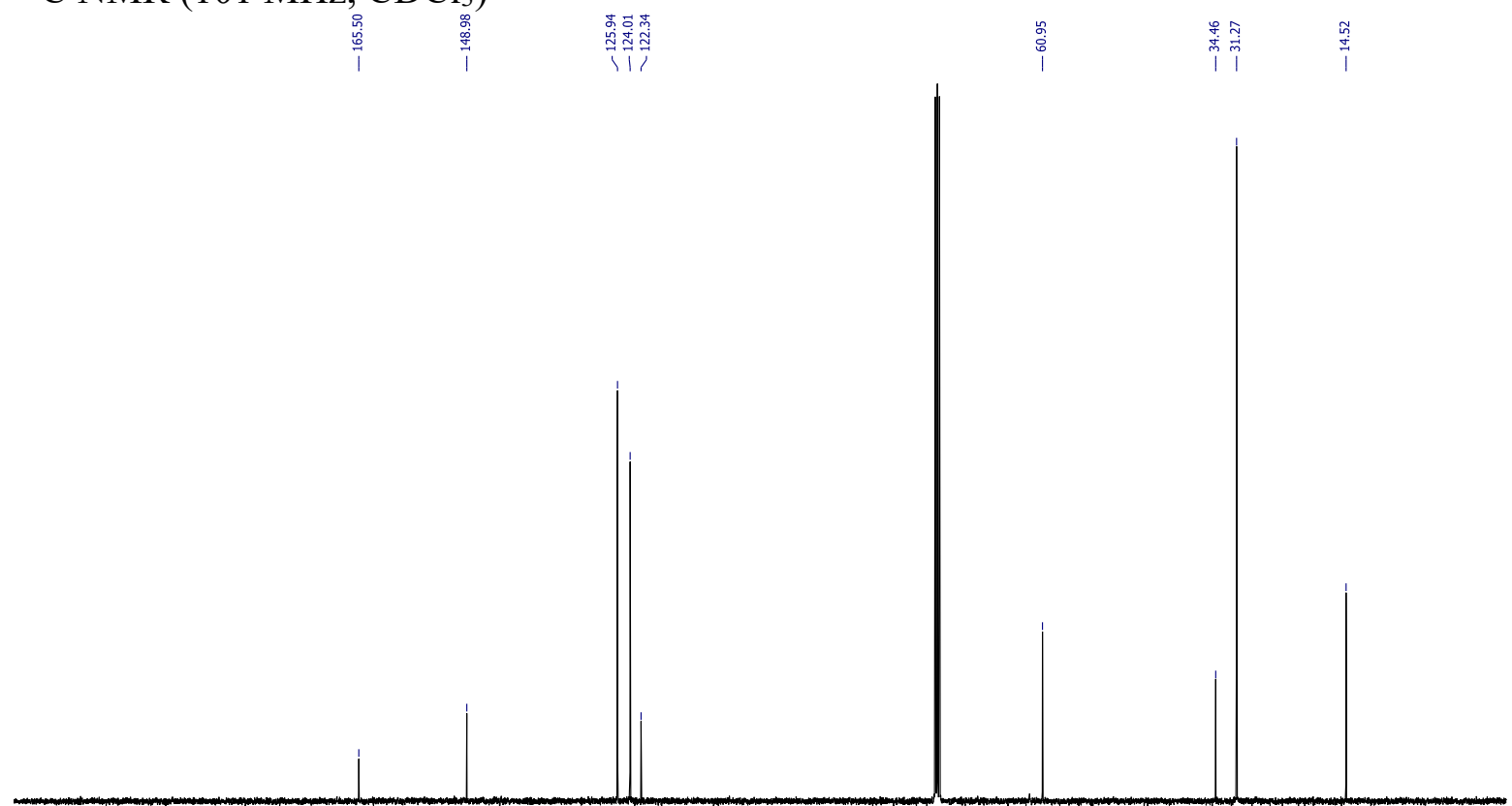

$\begin{array}{lllllllllllllllllllllllll}210 & 200 & 190 & 180 & 170 & 160 & 150 & 140 & 130 & 120 & 110 & 100 & 90 & 80 & 70 & 60 & 50 & 40 & 30 & 20 & 10 & 0 & -\end{array}$ 
<smiles>CCOC(=O)C(=N)c1ccc(OC)cc1</smiles>

${ }^{1} \mathrm{H}$ NMR (400 MHz, $\mathrm{CDCl}_{3}$ )

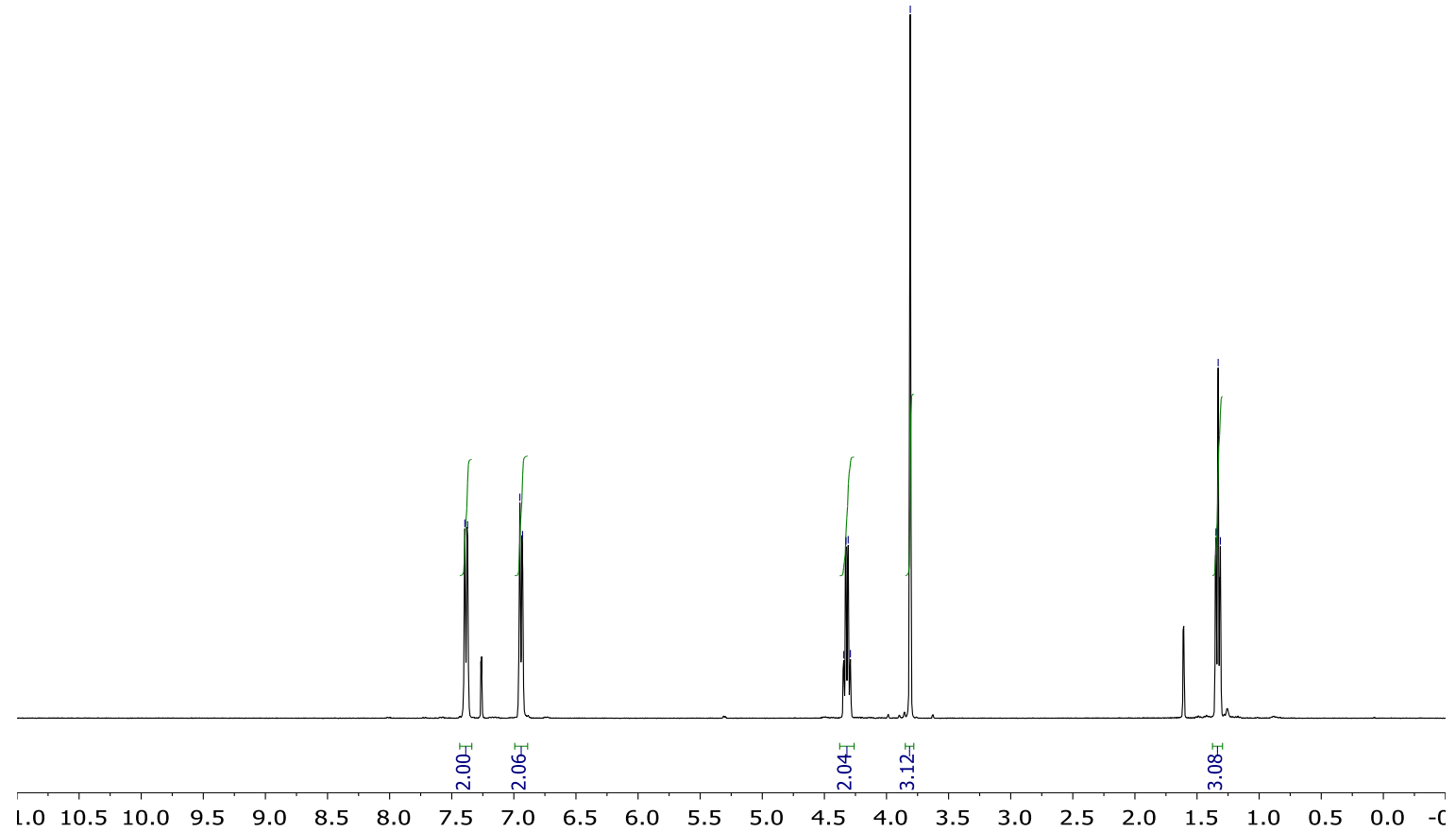

${ }^{13} \mathrm{C} \mathrm{NMR}\left(101 \mathrm{MHz}, \mathrm{CDCl}_{3}\right)$

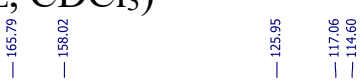

萿

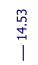

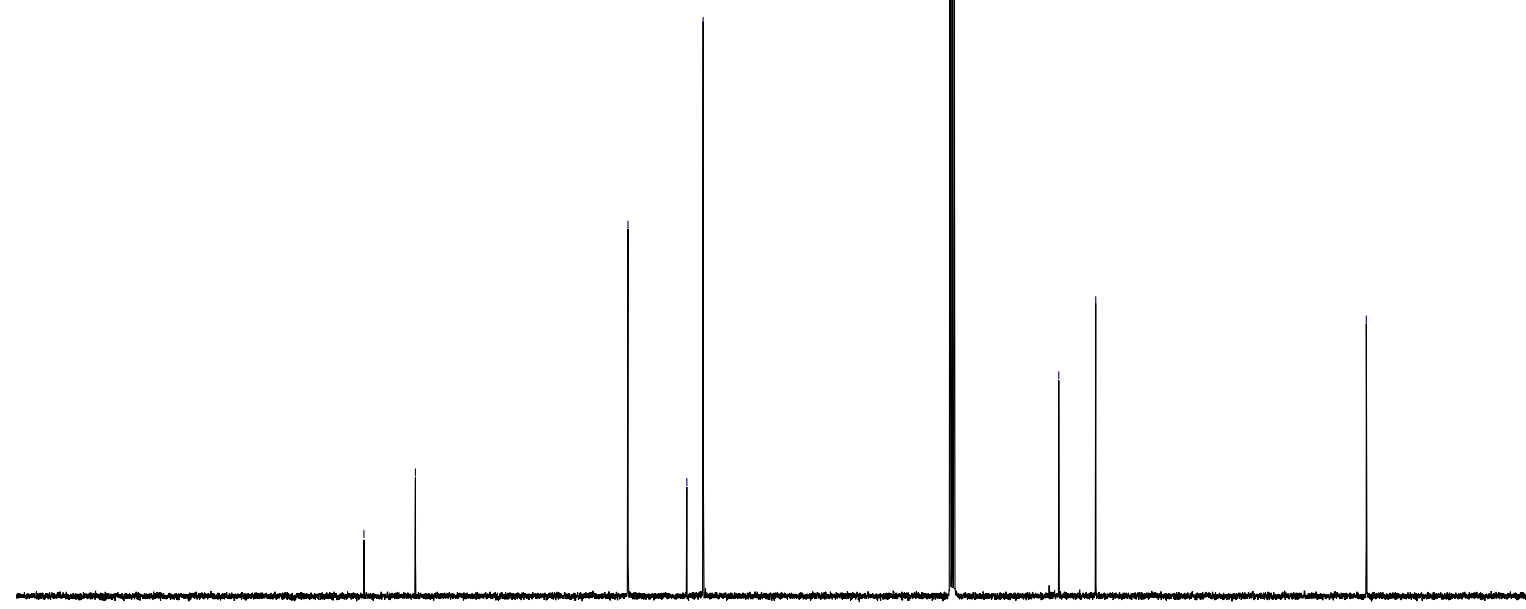


<smiles>CCOC(=O)C(C#N)c1ccc(Cl)nc1</smiles>

(14)

${ }^{1} \mathrm{H} \mathrm{NMR}\left(600 \mathrm{MHz}, \mathrm{CDCl}_{3}\right)$

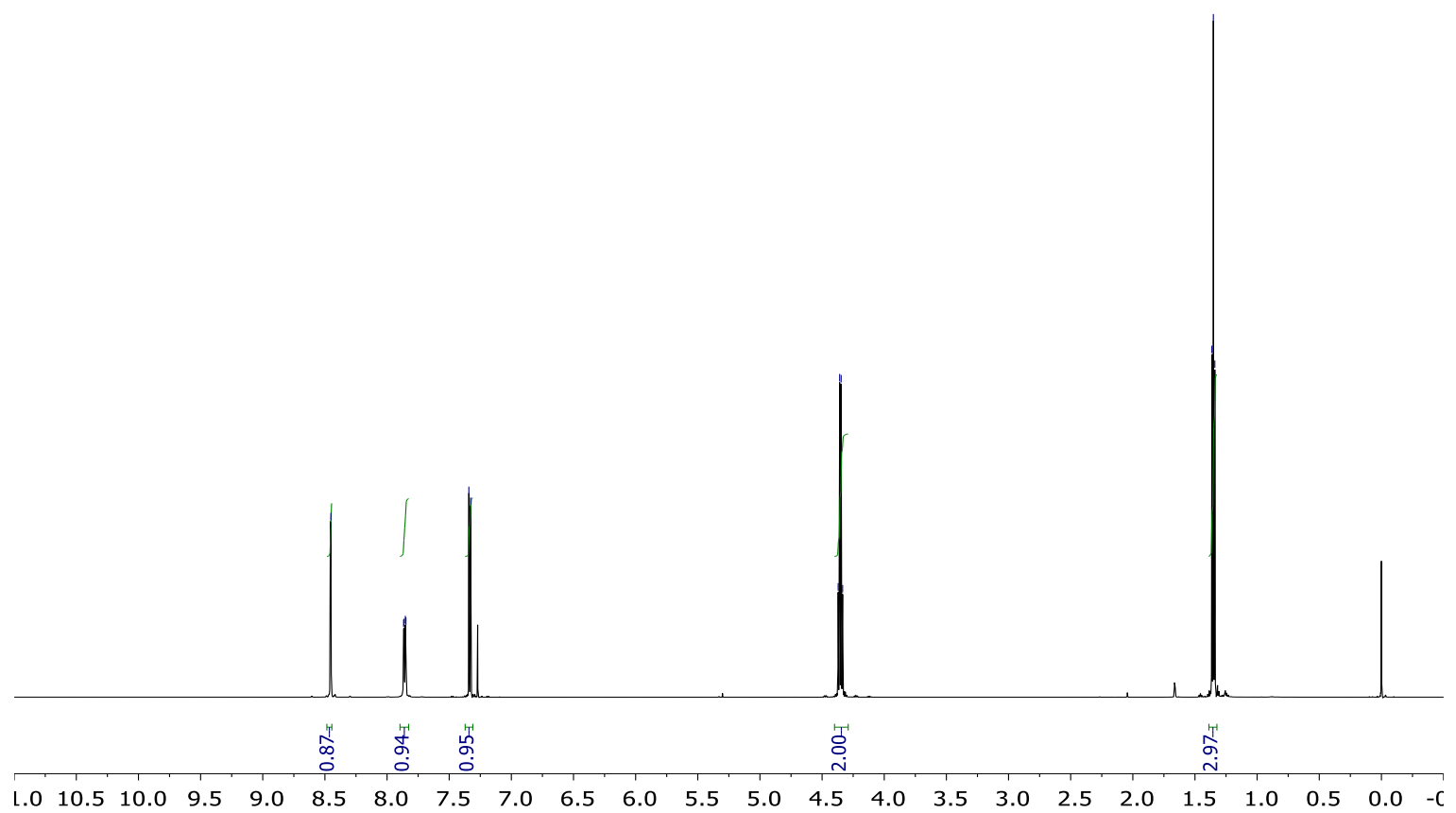

${ }^{13} \mathrm{C}$ NMR (151 MHz, $\left.\mathrm{CDCl}_{3}\right)$

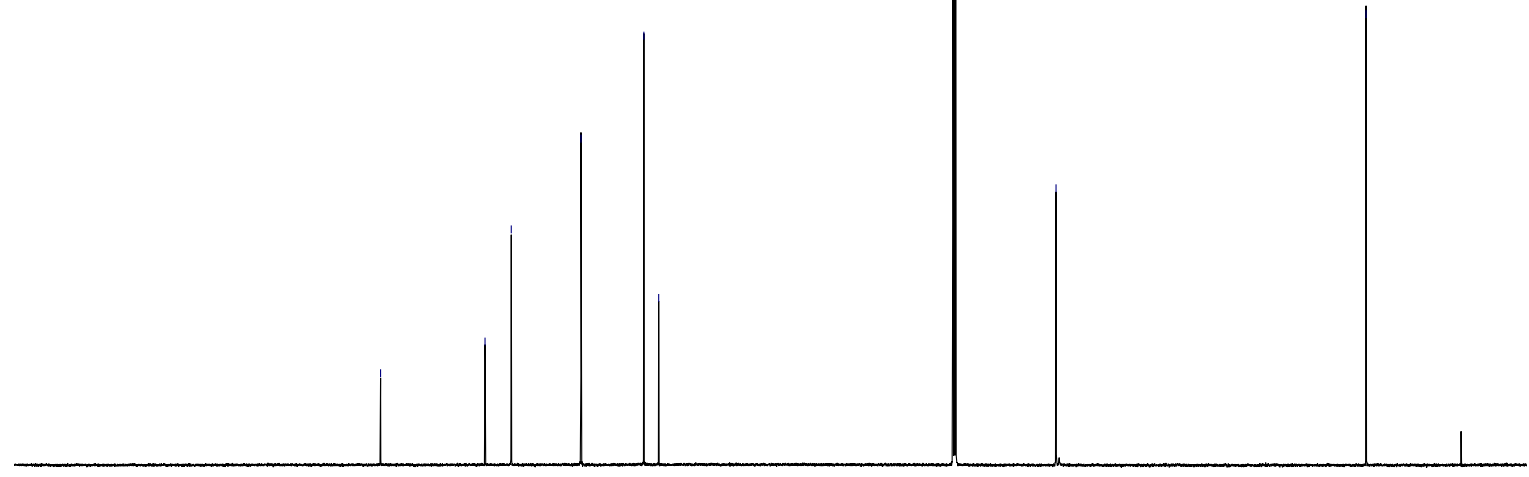


$m_{0}^{\mathrm{N}_{2}} \mathrm{CH}_{3}$

${ }^{1} \mathrm{H} \mathrm{NMR}\left(600 \mathrm{MHz}, \mathrm{CDCl}_{3}\right)$

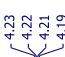

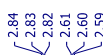

족ำำ
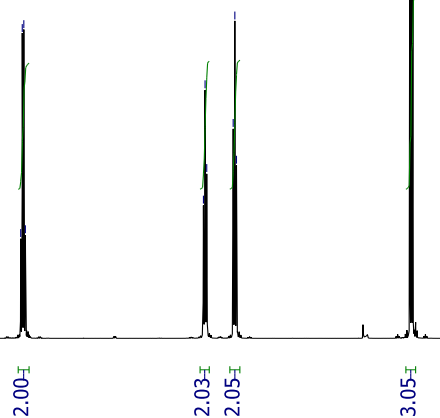

\begin{tabular}{lllllllllllllllllllllllllllll}
\hline 1.0 & 10.5 & 10.0 & 9.5 & 9.0 & 8.5 & 8.0 & 7.5 & 7.0 & 6.5 & 6.0 & 5.5 & 5.0 & 4.5 & 4.0 & 3.5 & 3.0 & 2.5 & 2.0 & 1.5 & 1.0 & 0.5 & 0.0 & $-\mathrm{C}$
\end{tabular} ${ }^{13} \mathrm{C} \mathrm{NMR}\left(151 \mathrm{MHz}, \mathrm{CDCl}_{3}\right)$

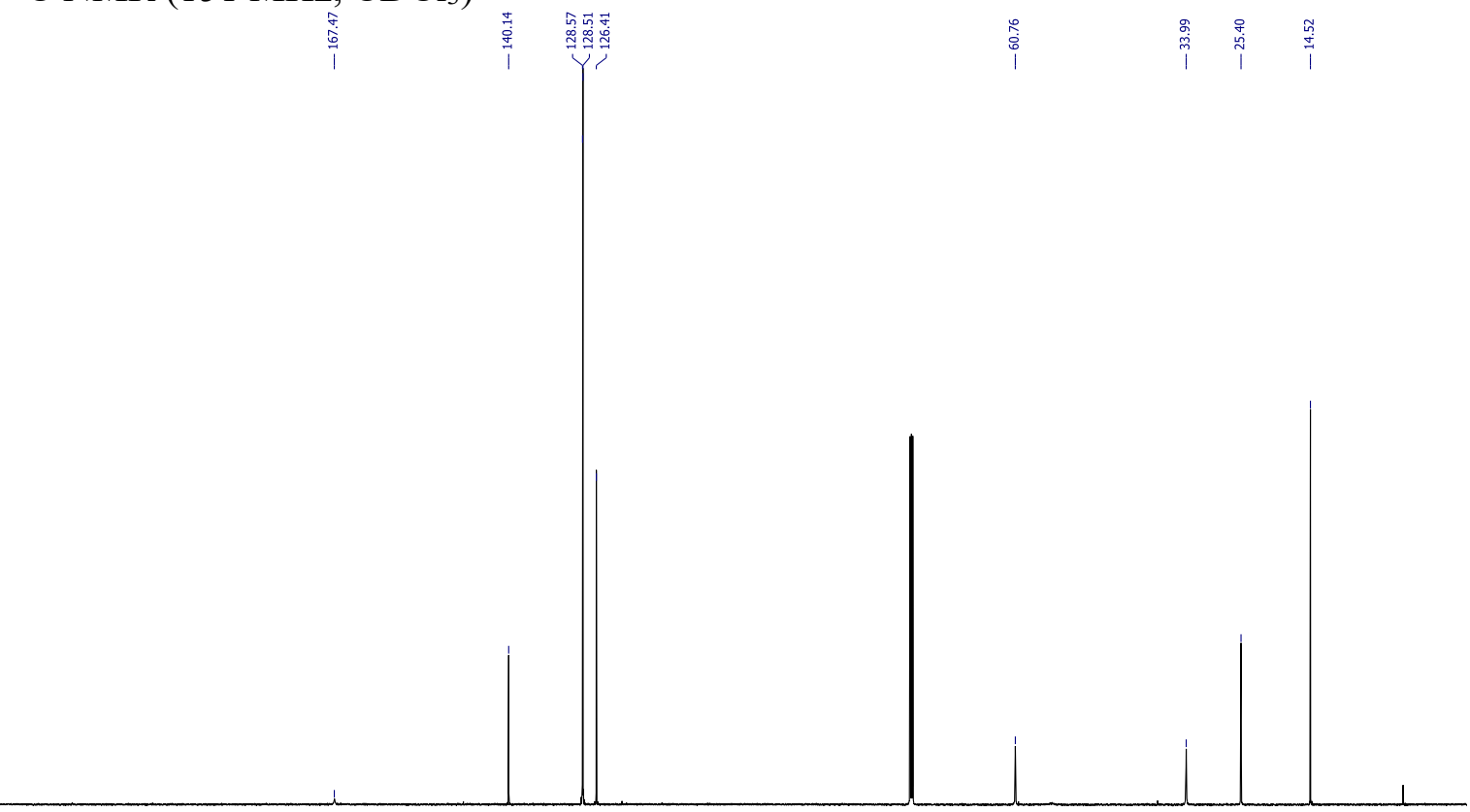

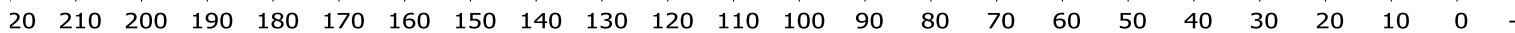


<smiles>N=C(C(=O)c1ccc(Br)cc1)c1ccc(Br)cc1</smiles>

(16)

${ }^{1} \mathrm{H} \mathrm{NMR}\left(600 \mathrm{MHz}, \mathrm{CDCl}_{3}\right)$

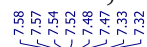
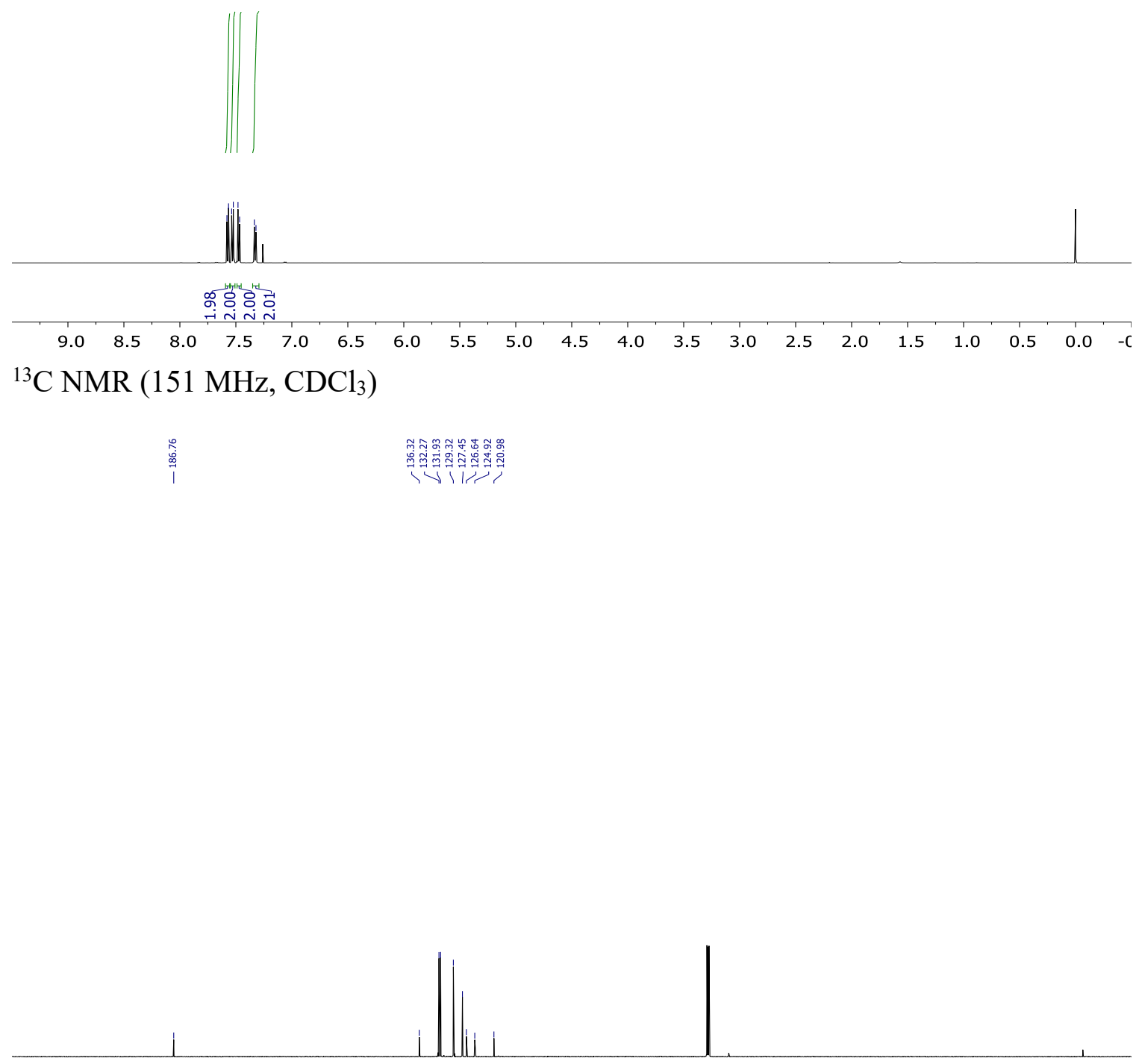

$20 \begin{array}{llllllllllllllllllllllll} & 210 & 200 & 190 & 180 & 170 & 160 & 150 & 140 & 130 & 120 & 110 & 100 & 90 & 80 & 70 & 60 & 50 & 40 & 30 & 20 & 10 & 0 & -:\end{array}$ 
<smiles></smiles>

${ }^{1} \mathrm{H}$ NMR (600 MHz, $\left.\mathrm{CD}_{3} \mathrm{OD}\right)$

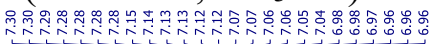

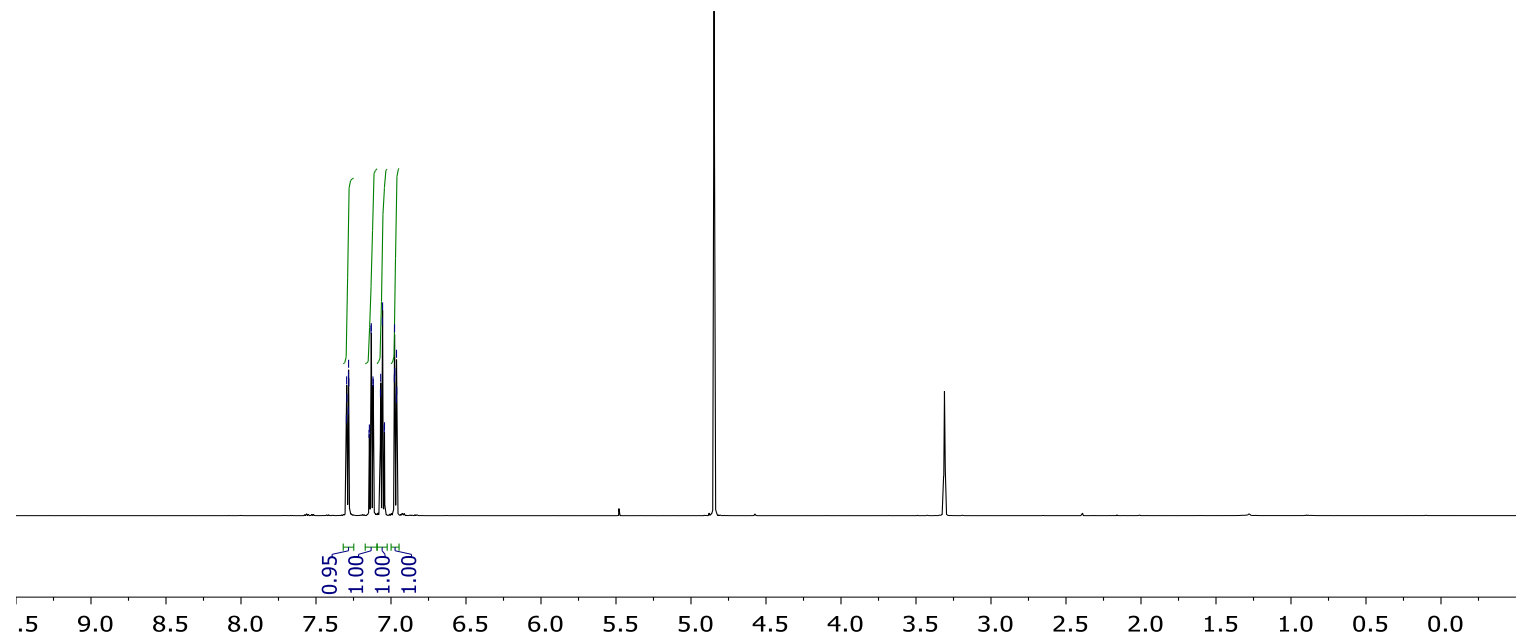

${ }^{13} \mathrm{C}$ NMR (151 MHz, CD $\left.3 \mathrm{OD}\right)$
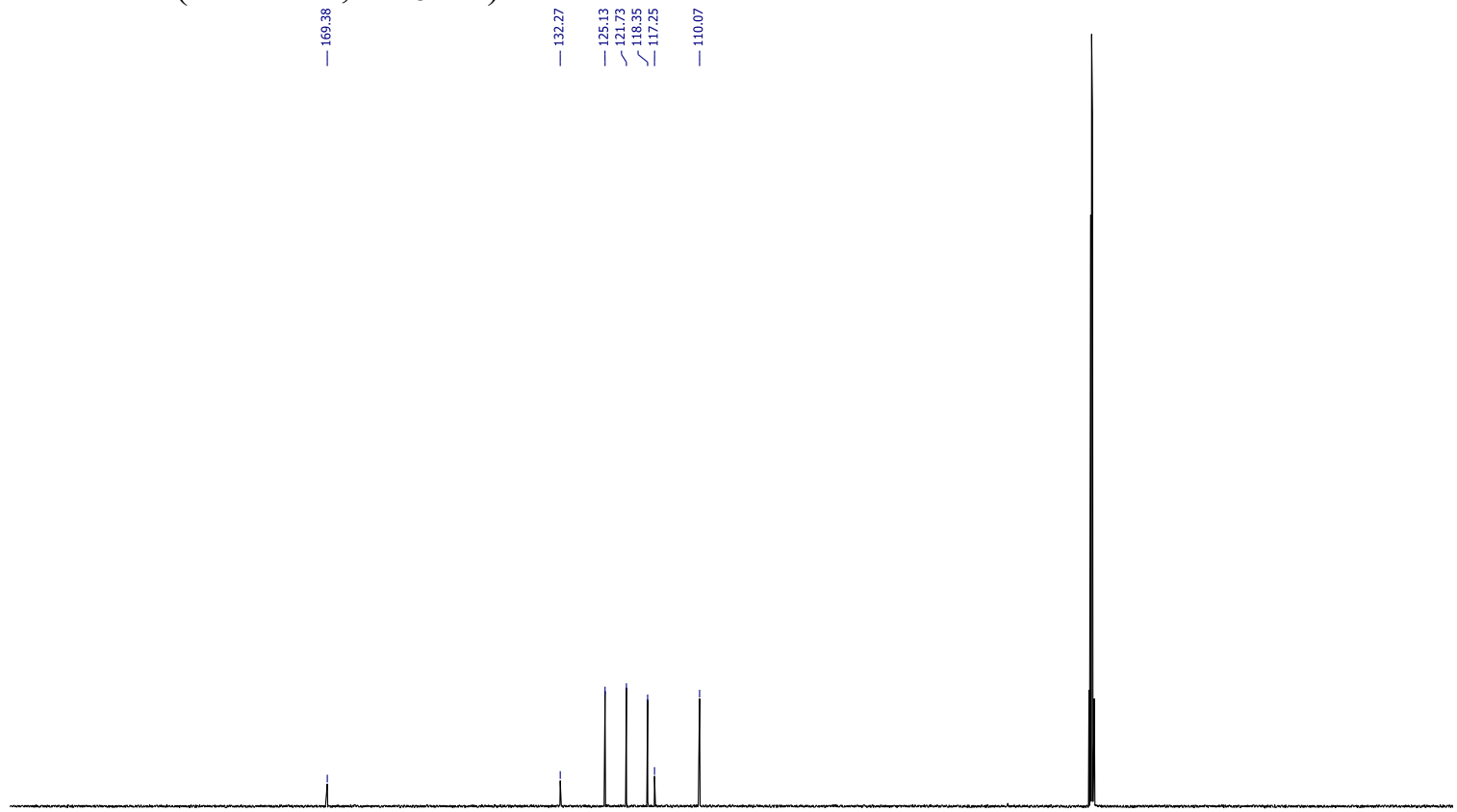

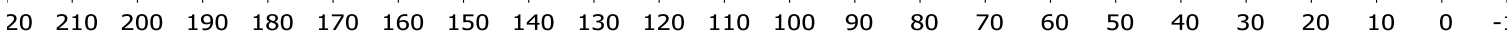


$\mathrm{N}_{\mathrm{CH}_{3}}^{\mathrm{N}=\mathrm{(18)}}$

${ }^{1} \mathrm{H}$ NMR (600 MHz, $\left.\mathrm{CDCl}_{3}\right)$

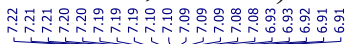

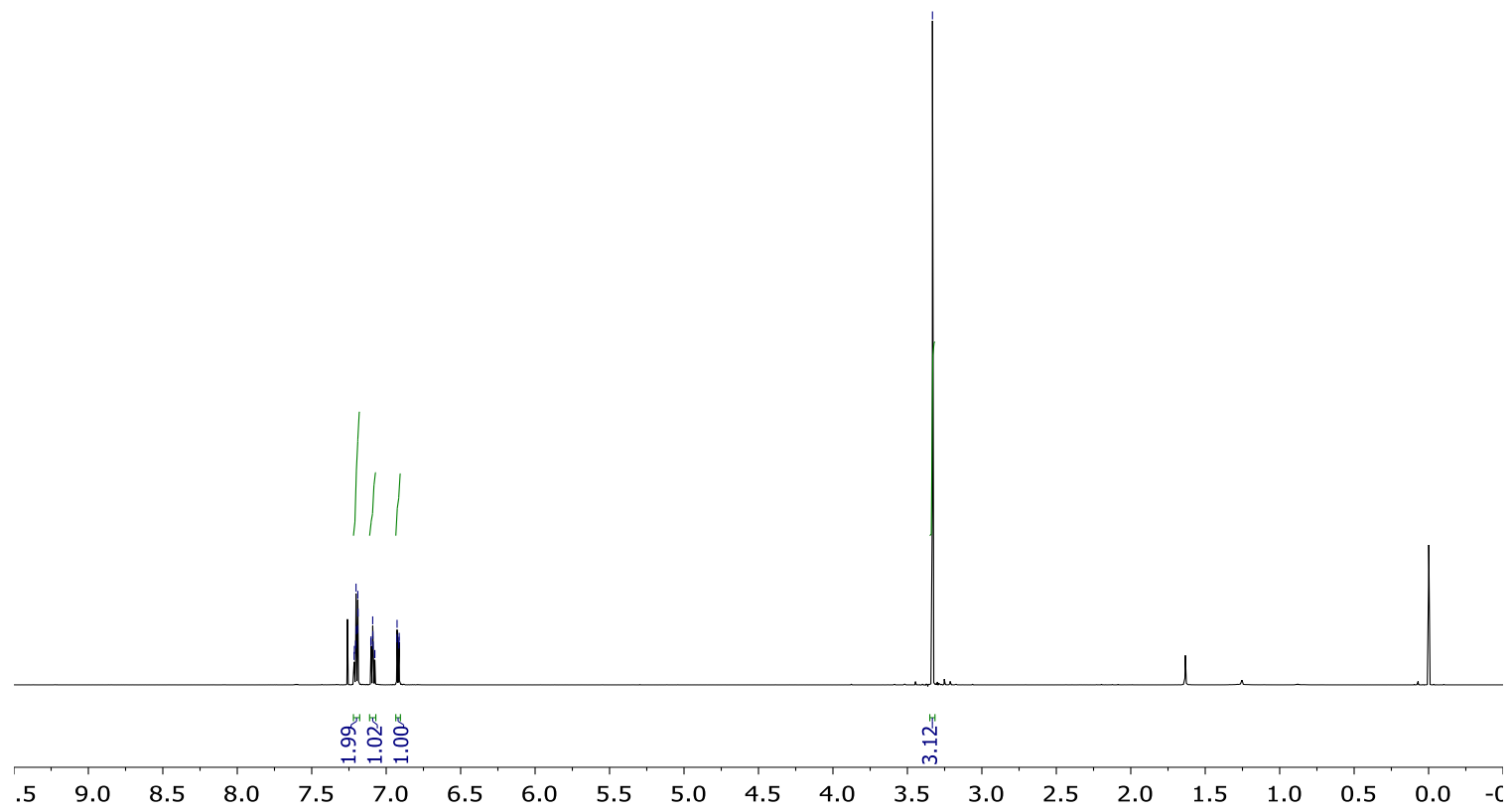
${ }^{13} \mathrm{C} \mathrm{NMR}\left(151 \mathrm{MHz}, \mathrm{CDCl}_{3}\right)$
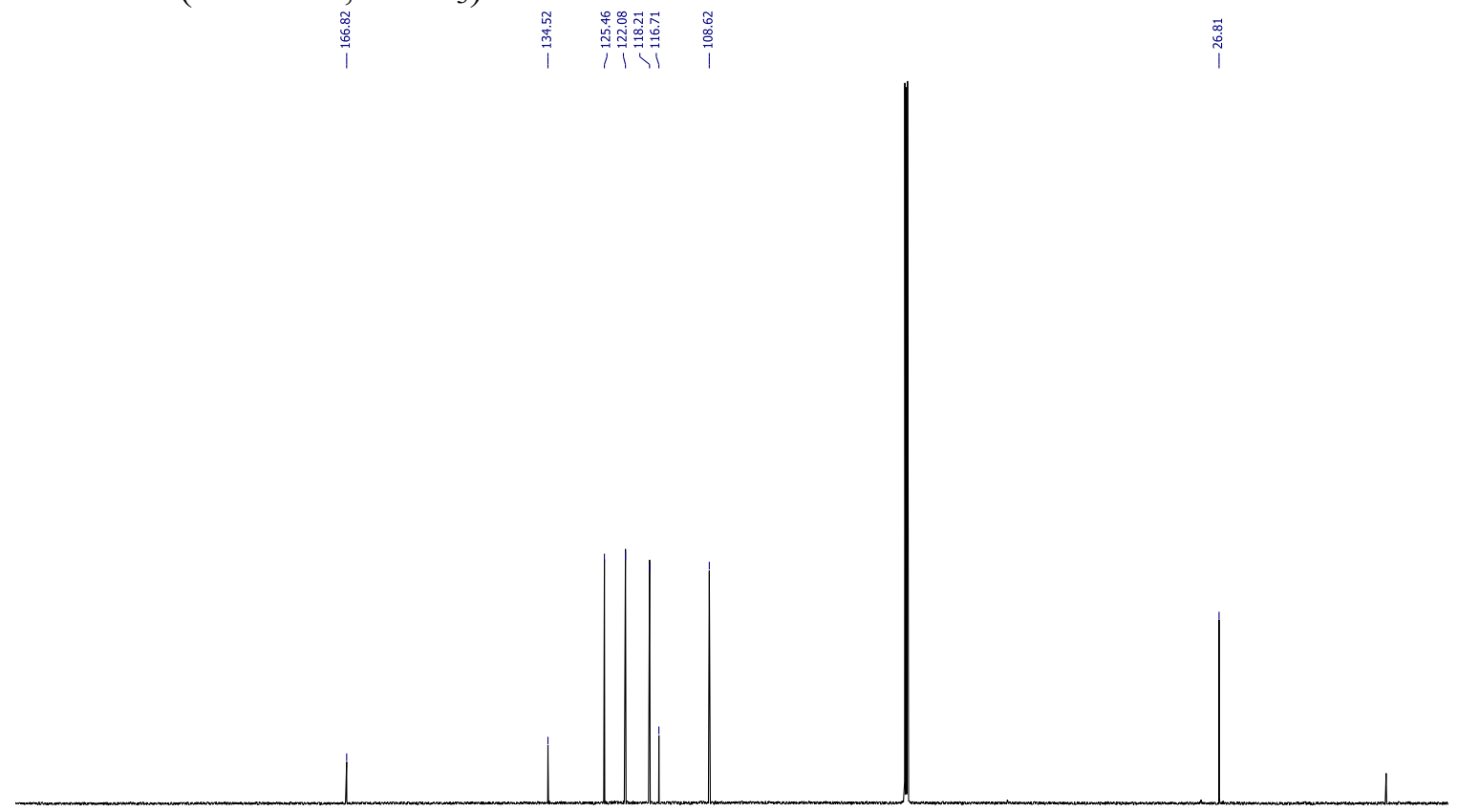

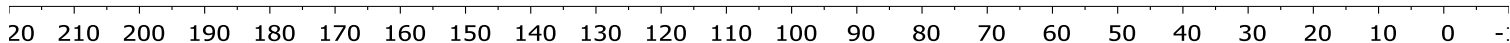


${ }^{1} \mathrm{H}$ NMR $\left(400 \mathrm{MHz}, \mathrm{CDCl}_{3}\right)$

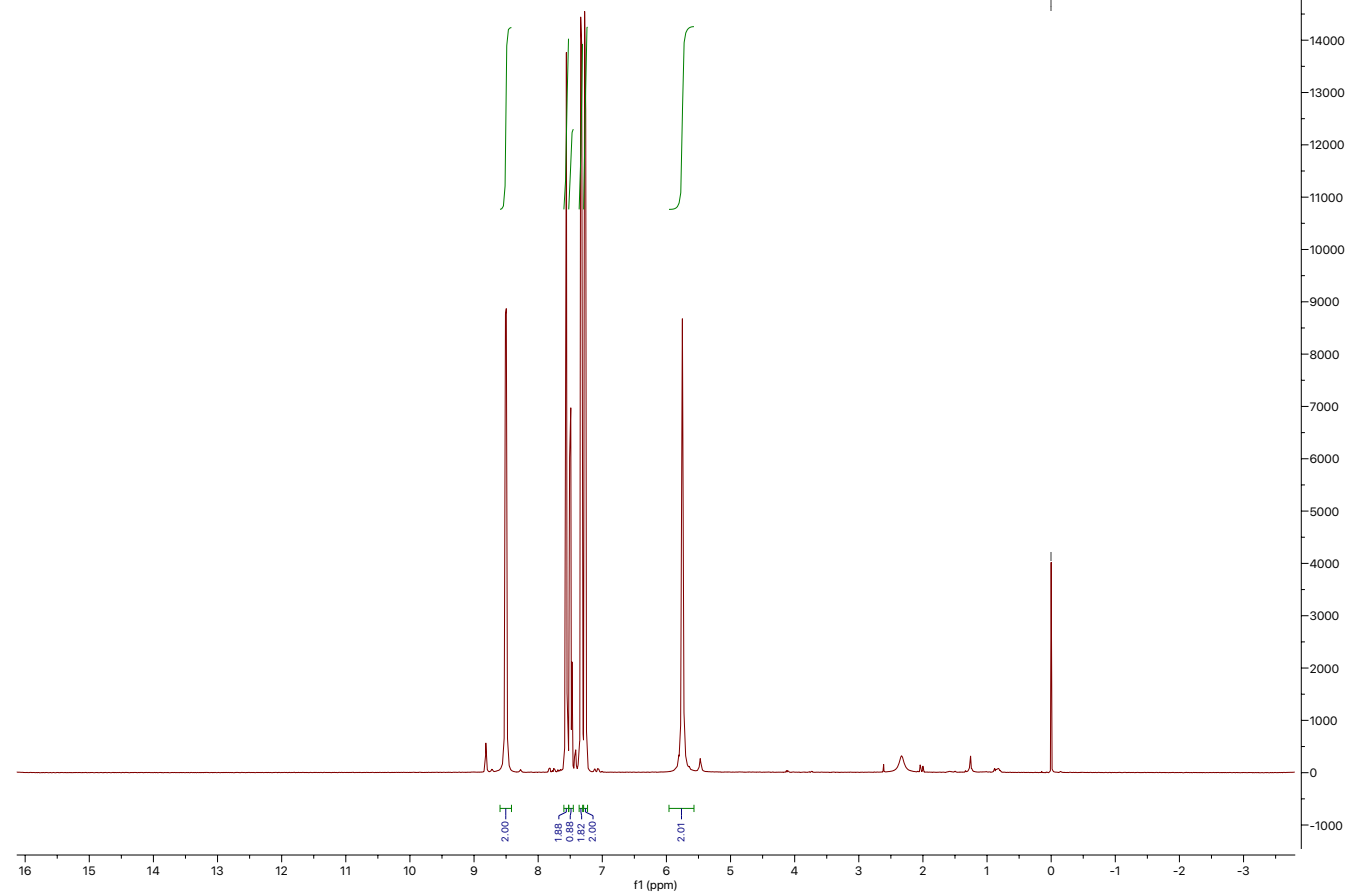

${ }^{13} \mathrm{C} \mathrm{NMR}\left(101 \mathrm{MHz}, \mathrm{CDCl}_{3}\right)$

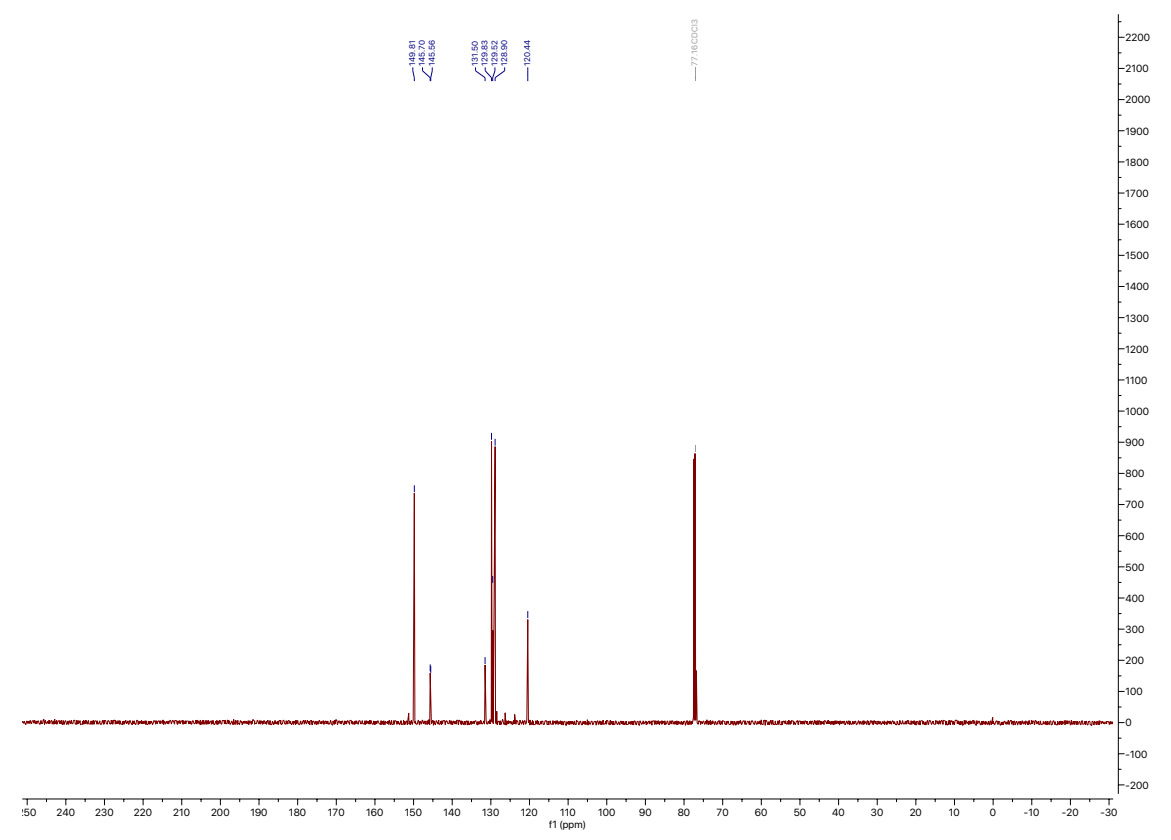


<smiles>N/N=C(/c1ccccc1)c1cccnc1</smiles>

${ }^{1} \mathrm{H}$ NMR (400 MHz, $\mathrm{CDCl}_{3}$ )

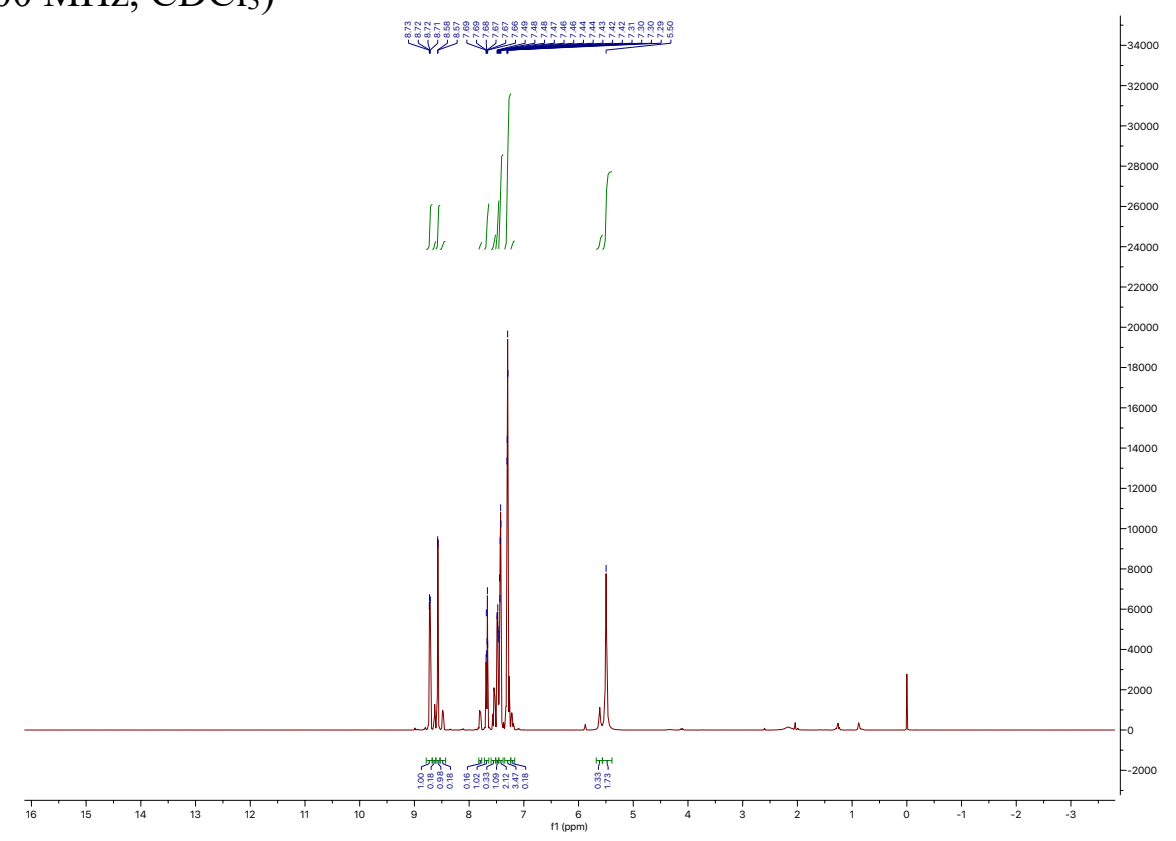

${ }^{13} \mathrm{C} \mathrm{NMR}\left(101 \mathrm{MHz}, \mathrm{CDCl}_{3}\right)$

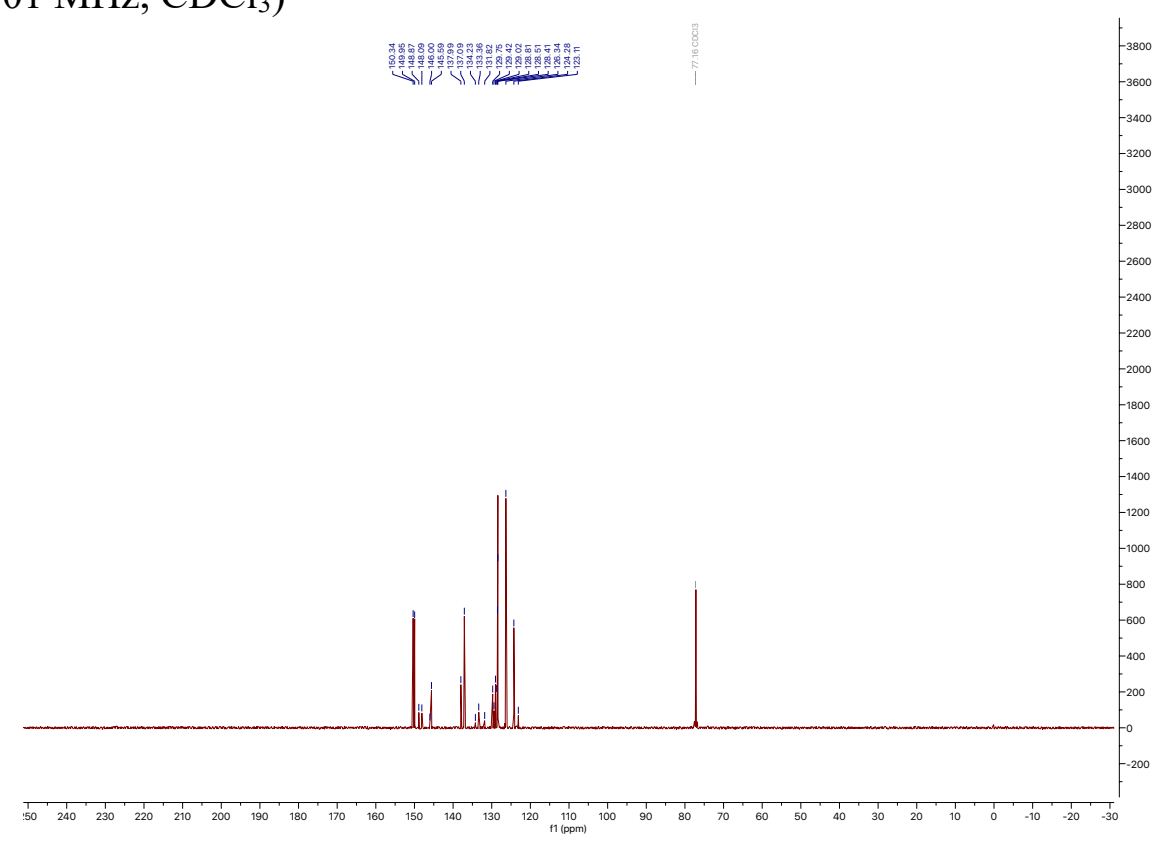


<smiles>N#CC(c1ccccc1)c1ccncc1</smiles>

${ }^{1} \mathrm{H}$ NMR (400 MHz, acetone-d6)

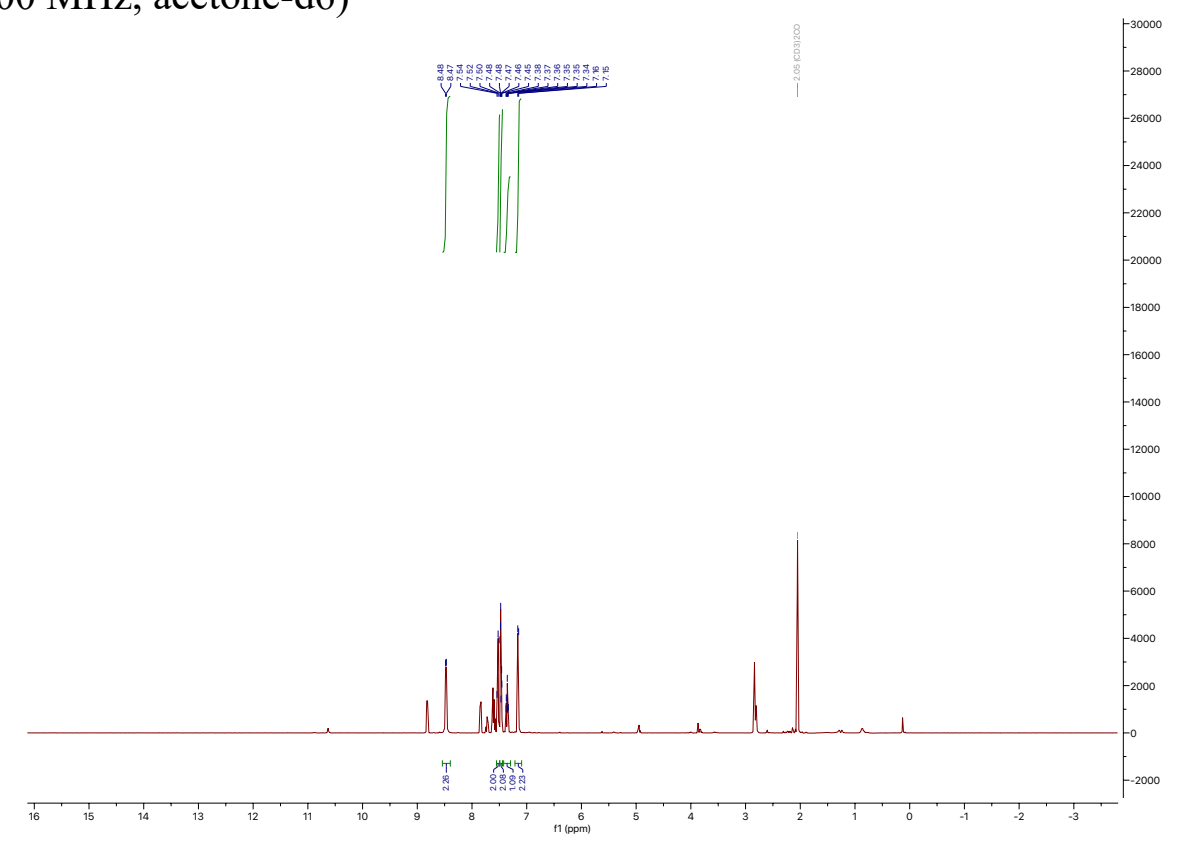

${ }^{13} \mathrm{C}$ NMR (101 MHz, acetone-d6)

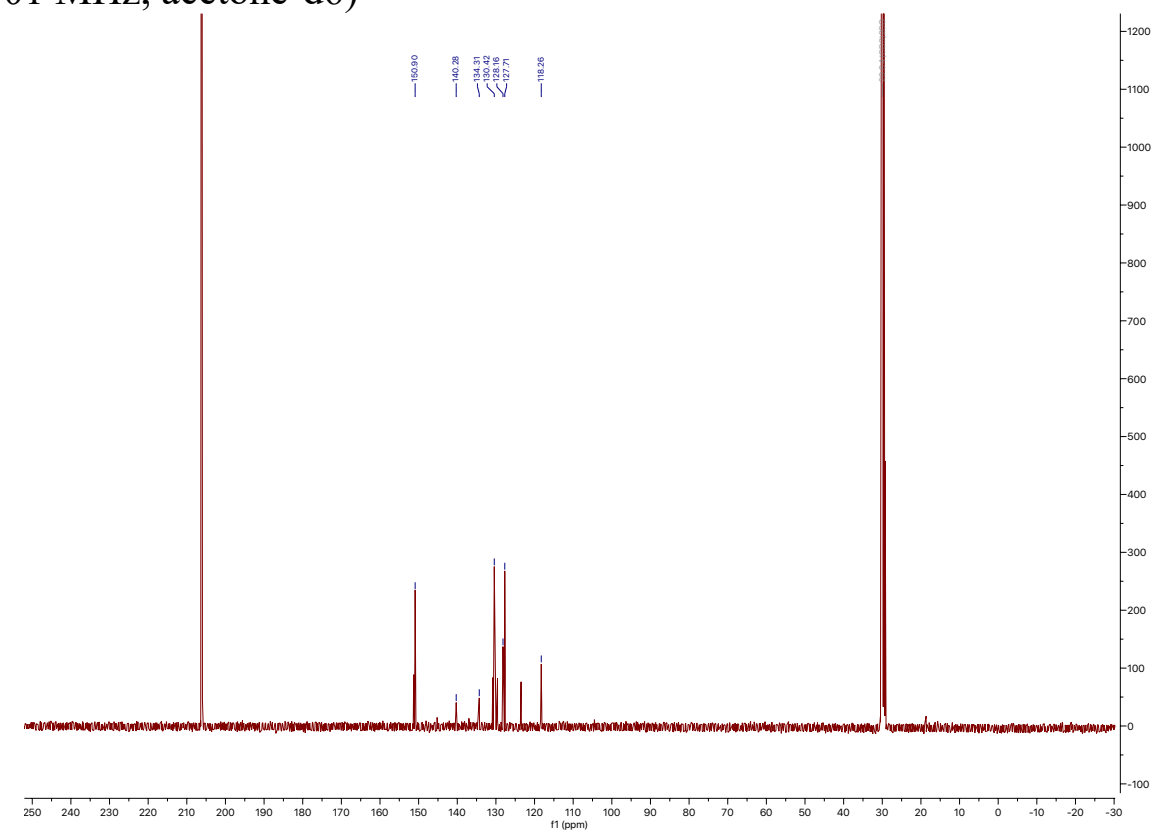


HMBC
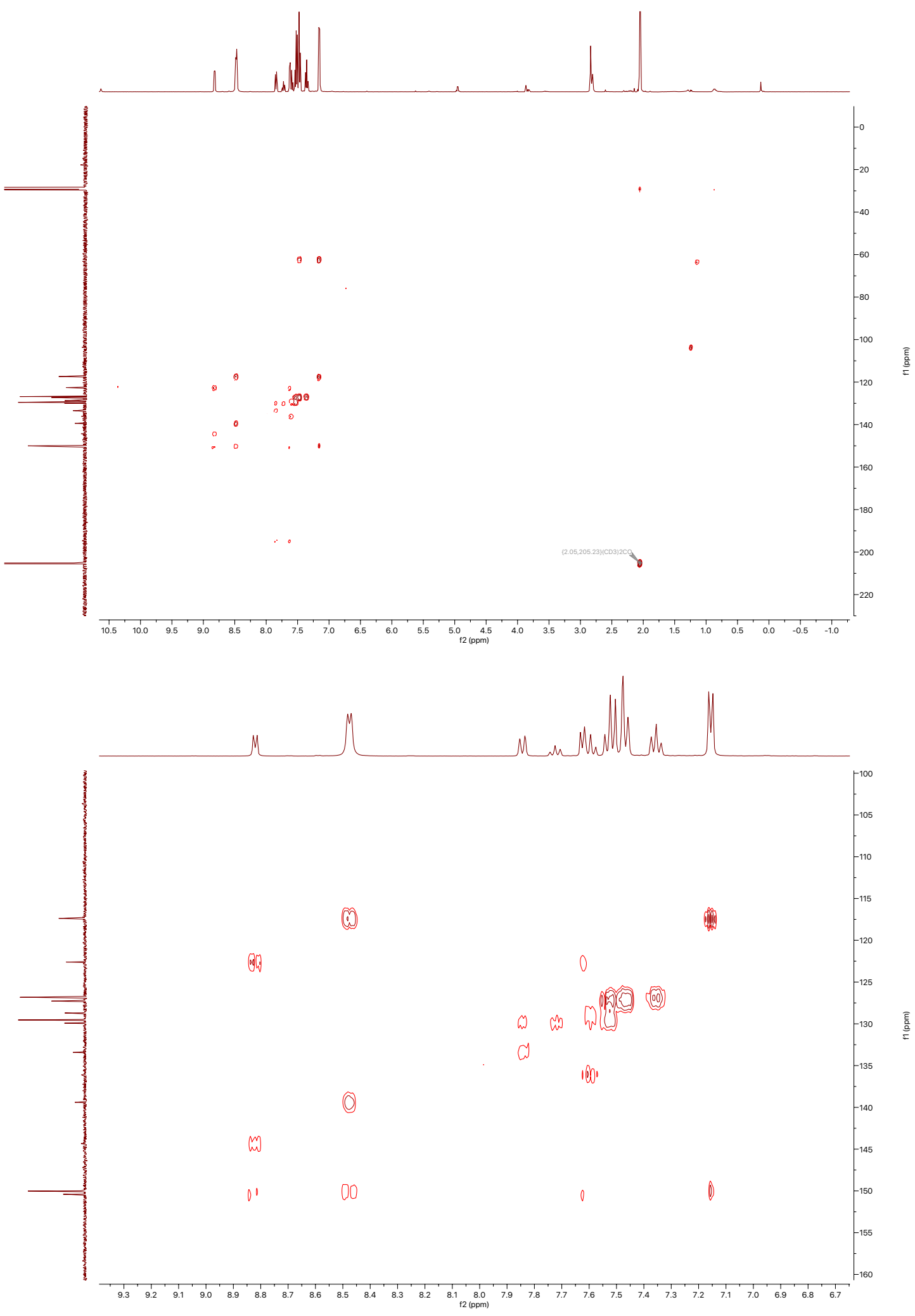
<smiles>N=C(c1ccccc1)c1cccnc1</smiles>

${ }^{1} \mathrm{H}$ NMR (400 MHz, acetone-d6)

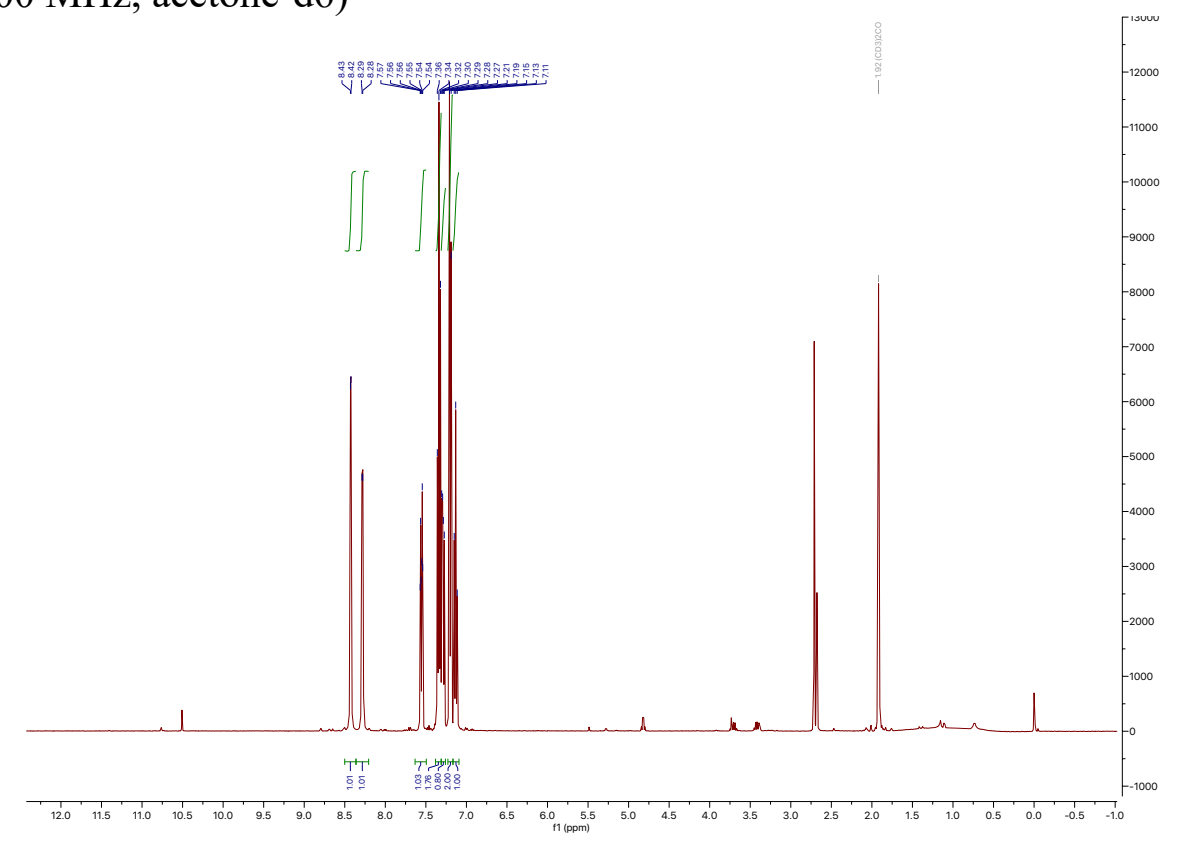

${ }^{13} \mathrm{C}$ NMR (101 MHz, acetone-d6)

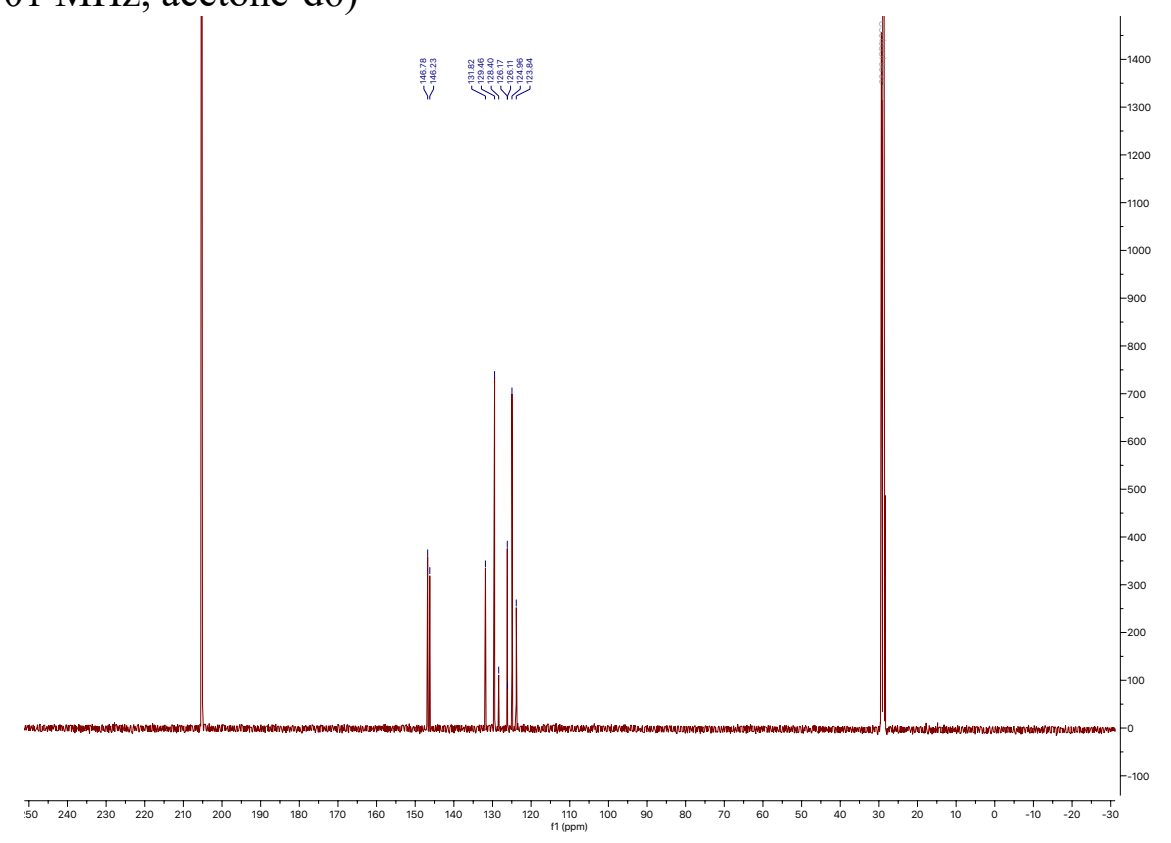




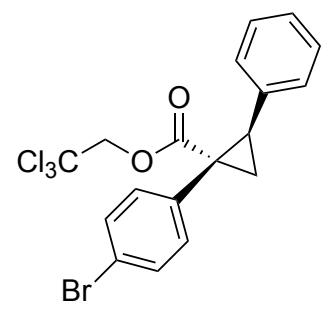

(31)

${ }^{1} \mathrm{H}$ NMR $\left(400 \mathrm{MHz}, \mathrm{CDCl}_{3}\right)$

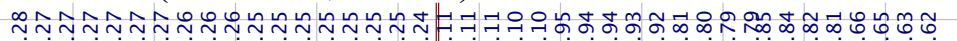

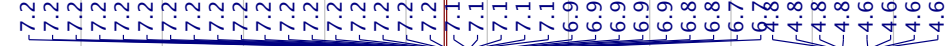

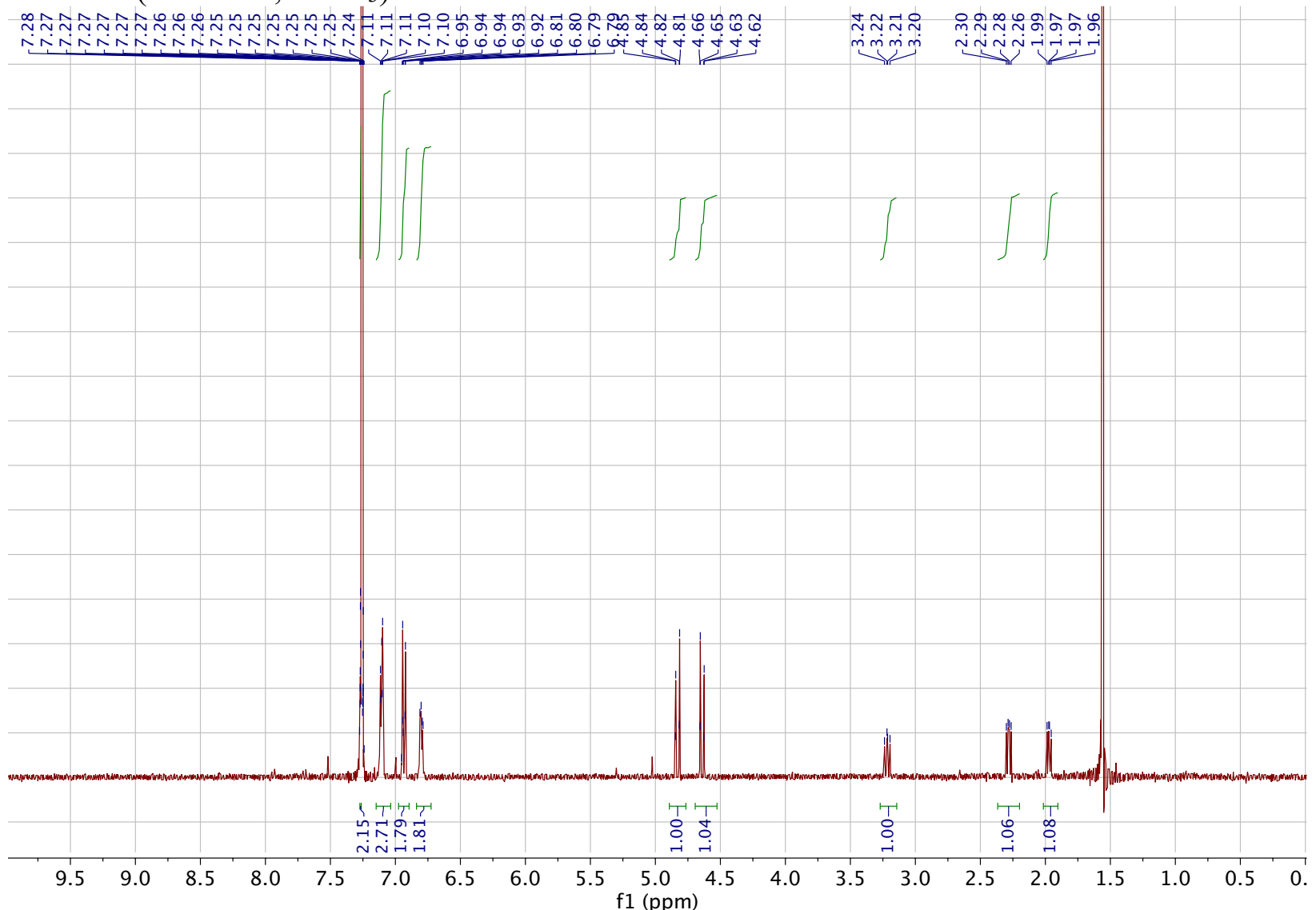


<smiles>O=[N+]([O-])c1ccc(C2(c3ccccc3)CC2c2ccccc2)cc1</smiles>

(32)

${ }^{1} \mathrm{H}$ NMR (600 MHz, $\mathrm{CDCl}_{3}$ )

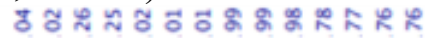

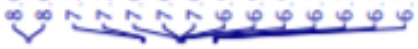
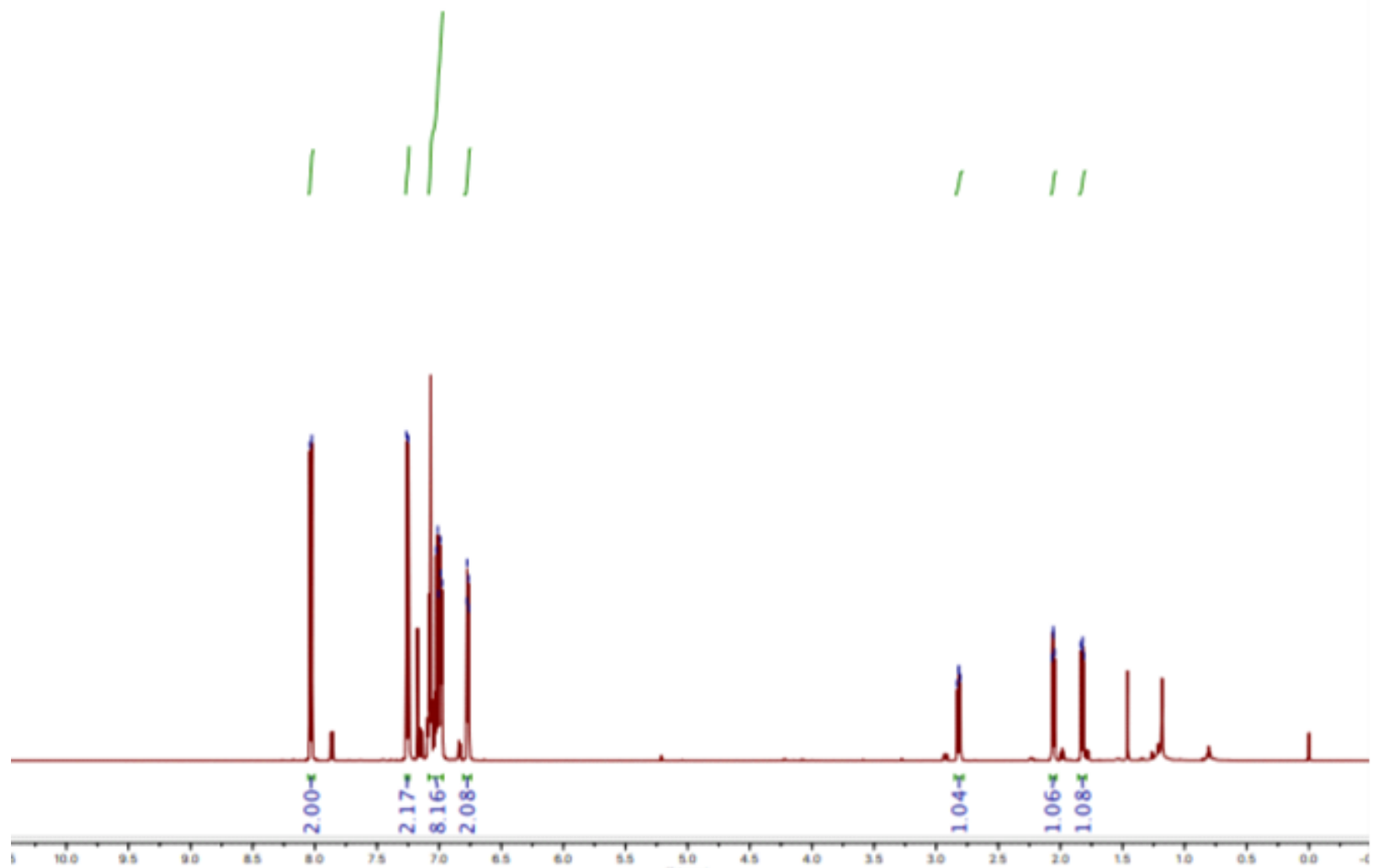

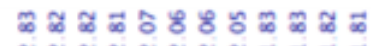

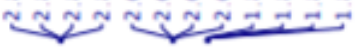

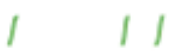

